\title{
Site U1306
}

\author{
Expedition 303 Scientists $^{2}$
}

\section{Chapter contents}

Background and objectives.......... 1

Operations...................

Lithostratigraphy............... 3

Biostratigraphy .............. 5

Paleomagnetism ............... 7

Composite section. . . . . . . . . . . 8

Geochemistry ................8

Physical properties ................ 10

References ................... 11

Figures $\ldots \ldots \ldots \ldots \ldots \ldots \ldots \ldots$

Tables ................... 53

'Expedition 303 Scientists, 2006. Site U1306. In Channell, J.E.T., Kanamatsu, T., Sato, T., Stein, R., Alvarez Zarikian, C.A., Malone, M.J., and the Expedition 303/306 Scientists. Proc. IODP, 303/ 306: College Station TX (Integrated Ocean Drilling Program Management International, Inc.). doi:10.2204/iodp.proc.303306.106.2006 'Expedition 303 Scientists' addresses.

\section{Background and objectives}

Integrated Ocean Drilling Program Site U1306 is located on the Eirik Drift in $2272 \mathrm{~m}$ water depth, $190.7 \mathrm{~km}$ (102.9 nmi) northeast of Site U1305 (Fig. F1). Site U1306 provides a shallower water depth site than Site U1305, which is located in $3459 \mathrm{~m}$ water depth. As discussed in "Background and objectives" in the "Site U1305" chapter, the difference in water depth between the two sites generates a contrasting sedimentation pattern largely because of the behavior of the Western Boundary Undercurrent (WBUC). The WBUC shallows and becomes less intense during glacial intervals, resulting in relatively expanded glacial intervals at Site U1306 and, in contrast, relatively expanded interglacial intervals at Site U1305.

Core HU90-013-012, at $58.92^{\circ} \mathrm{N}, 47.12^{\circ} \mathrm{W}$, is located $114.5 \mathrm{~km}$ (61.8 nmi) northwest of Site U1306 (Fig. F1). This $12.4 \mathrm{~m}$ core, retrieved in $2830 \mathrm{~m}$ water depth, was collected from the CCGS Hudson in 1991. Cores MD99-2228 and MD99-2242 were collected in $2900 \mathrm{~m}$ water depth at almost the same location $\left(58.93^{\circ} \mathrm{N}\right.$, $47.14^{\circ} \mathrm{W}$ and $58.92^{\circ} \mathrm{N}, 47.13^{\circ} \mathrm{W}$, respectively) during the $1999 \mathrm{Im}$ ages cruise of the Marion-Dufresne (Turon et al., 1999). The susceptibility records from the two Marion-Dufresne cores can be correlated one to another and to Core HU90-013-012 (Fig. F2) and represent the best guide as to what to expect at Site U1306.

Core HU90-013-012 extends into marine isotope Stage (MIS) 6, with Holocene and MIS 5e being largely absent and restricted to a few decimeters at most (Hillaire-Marcel et al., 1994; Stoner et al., $1995,1998)$. The mean sedimentation rate between the base of the Holocene and the base of MIS $5 \mathrm{~d}$ is $\sim 9 \mathrm{~cm} / \mathrm{k}$.y. The contrasting sedimentation pattern between glacial and interglacial intervals is attributed to the location of the site at a water depth within the main axis of the WBUC (Fig. F1 in the "Site U1305" chapter). The axis of the WBUC was weaker and probably at a shallower water depth during glacial intervals, thereby facilitating deposition at the site (Hillaire-Marcel and Bilodeau, 2000).

For the purpose of generating a high-resolution record of the uppermost Pliocene and Quaternary from the Eirik Drift in the 2000-2500 $\mathrm{m}$ water depth range, we targeted a location where the mid-Upper Pliocene seismic Reflector R1 was deepest at the desired water depth. Using the multichannel seismic network obtained over the Eirik Drift during Knorr Cruise KN166-14 in summer 2002, Site U1306 was placed at the crossing of seismic Line 
19 and seismic Line 24c (Fig. F3 in the "Site 1305" chapter) at common depth point (CDP) 7435 on Line 24c and CDP 2550 on Line 19 (Fig. F3). The location is characterized by planar seismic reflectors, implying uncomplicated stratigraphy devoid of debris flows or mass transport deposits. At Site U1306, seismic Reflector R1 lies at an estimated depth of 420 meters below seafloor (mbsf) (0.27 s), indicating a mean sedimentation rate since mid-Late Pliocene of $\sim 14 \mathrm{~cm} / \mathrm{k} . \mathrm{y}$. The achieved penetration at Site U1306 (294.8 mbsf) is indicated in Figure F3, and the mean sedimentation rate for the recovered section was found to be $\sim 15 \mathrm{~cm} / \mathrm{k} . \mathrm{y}$. The $3.5 \mathrm{kHz}$ data along seismic Line 19 are also shown (Fig. F4).

As explained above and in the "Site U1305" chapter, the objectives at Site U1306 and Site U1305 are closely linked. The two sites are expected to exhibit contrasting sedimentation patterns. Glacial MISs at Site U1306 are expected to be relatively expanded and interglacial stages relatively condensed. The opposite pattern is expected at Site U1305. This alternating pattern provides a high-sedimentation-rate (high resolution) composite record at the two sites and will constrain the activity of the WBUC during the Quaternary.

For Sites U1302, U1303, U1305, and U1306, the detrital layer stratigraphy, characterized by both detrital-carbonate layers and low-detrital-carbonate layers, provides a proxy for episodes of instability of the surrounding ice sheets, particularly the Laurentide and Greenland Ice Sheets. Detritus from the Greenland Ice Sheet was delivered to Site U1306 through slope gullies and then entrained in contour currents to the site (Cremer, 1989; Hiscott et al., 1989). Detritus derived from the Laurentide Ice Sheet was delivered as ice-rafted debris or as spillover turbidites from the Northwest Atlantic Mid-Ocean Channel, with the fine fraction deposited from suspension at Sites U1305 and U1306. The detrital layer stratigraphy at Site U1306 will be correlated with the detrital layer stratigraphies at Sites U1302, U1303, and U1305 and with the classic Heinrich-layer stratigraphy of the central Atlantic. The isotopic signature from both planktonic and benthic foraminifers and the microfossil assemblages will provide information on water mass structure, meltwater pulses, sea-surface temperatures, the activity of the West Greenland Current and WBUC, and, hence, the formation of North Atlantic Deep Water (Fig. F1 in the "Site 1305" chapter). The high mean sedimentation rate at Site U1306 (15 cm/k.y.), with more elevated sedimentation rates during glacial intervals, implies that this environmental record will have high resolution. In addition, the record has the attributes for excellent stratigraphic age control within the context of a paleointensity-assisted chronostratigraphy.

\section{Operations}

The $103 \mathrm{nmi}$ transit from Site U1305 to Site U1306 (LAB7A) took $11.3 \mathrm{~h}$ at an average speed of $9.1 \mathrm{kt}$. Upon arrival at the site coordinates, the thrusters were lowered and the beacon was deployed at $0130 \mathrm{~h}$ on 23 October 2004, officially initiating operations at Site U1306.

\section{Hole U1306A}

With the bit positioned at 2280.4 meters below rig floor (mbrf) (8 $\mathrm{m}$ shallower than the calculated precision depth recorder depth), Hole U1306A was spudded with the advanced piston corer (APC) at $0910 \mathrm{~h}$. Recovery for Core $1 \mathrm{H}$ was $8.3 \mathrm{~m}$, suggesting a seafloor depth of 2270.5 meters below sea level (mbsl) (2281.6 mbrf). A total of 33 piston cores were collected to a total depth of 304.3 mbsf, with an average recovery of $101.2 \%$ for the cored interval. Core orientation and use of nonmagnetic core barrels are shown in Table T1. Core $16 \mathrm{H}$ was only able to advance $0.5 \mathrm{~m}$ (141.3-141.8 mbsf), and the interval from 141.8 to 142.8 mbsf was drilled without coring. Core $29 \mathrm{H}$ was the only core barrel that required drillover. After achieving the depth objective, coring was halted and the bit was pulled clear of the seafloor at $1550 \mathrm{~h}$ on 24 October 2004, ending operations in Hole U1306A.

\section{Hole U1306B}

The ship was offset $30 \mathrm{~m}$ east of Hole U1306A, and the bit was positioned $4.5 \mathrm{~m}$ shallower than at Hole U1306A. Hole U1306B was initiated at $1710 \mathrm{~h}$ on 24 October 2004 with recovery of a $1.36 \mathrm{~m}$ core (Core $1 \mathrm{H})$, suggesting a seafloor depth of $2273 \mathrm{mbsl}$ (2284.1 mbrf). Piston coring and drilling advanced the hole to a total depth of $309.3 \mathrm{mbsf}$, with $103.5 \%$ average recovery for the cored interval. The interval from 162.8 to 166.8 mbsf was drilled to maintain appropriate stratigraphic offset with Hole U1306A. Four of the last five core barrels had to be drilled over (Cores $29 \mathrm{H}$ and $31 \mathrm{H}-33 \mathrm{H}$ ). The bit cleared the seafloor at $0330 \mathrm{~h}$ on 26 October, concluding operations in Hole U1306B.

\section{Hole U1306C}

After offsetting the vessel $30 \mathrm{~m}$ to the east, the bit was positioned $2.5 \mathrm{~m}$ deeper than in Hole U1306B. Hole U1306C was spudded at $0500 \mathrm{~h}$ on 26 October 2004 . Based on recovery of the first core $(0.96 \mathrm{~m})$, the seafloor depth was estimated to be $2274.8 \mathrm{mbsl}$. However, it is unlikely that this is a reasonable estimate because the deeper bit position should have produced a longer first core than in Hole U1306B. Piston coring and drilling advanced Hole U1306C to 
a total depth of 256.0 mbsf. Recovery in the cored section averaged $103.8 \%$. In addition to coring, two intervals were drilled (20.0-24.0 and 223.5-227.5 mbsf) to adjust stratigraphic overlap with the previous holes. Operations officially concluded when the bit cleared the seafloor at $0800 \mathrm{~h}$ on 27 October.

\section{Hole U1306D}

The ship was offset $30 \mathrm{~m}$ east of Hole U1306C, and Hole U1306D was initiated at $0910 \mathrm{~h}$ on 27 October 2004. The recovery of the initial core was $7.06 \mathrm{~m}$, suggesting a seafloor depth of $2271.8 \mathrm{mbsl}$ (2282.9 mbrf). Piston coring and drilling advanced the hole to a total depth of 180.0 mbsf, when coring was terminated after necessary stratigraphic overlap was achieved. Average recovery was $100.9 \%$ for the cored section. The interval from 83.0 to 85.0 mbsf was drilled to adjust overlap with previous holes.

Our original plan was to depart the Eirik Drift area for proposed Site IRD1A (Site U1308). However, a low-pressure system centered southeast of Newfoundland was moving slowly northeastward and was forecast to pass through the transit area and Site IRD1A location. As a result, we opted to core at nearby alternate Eirik Drift Site LAB8C and wait for a weather window to open that would allow a safe voyage to Site IRD1A. After retrieving the drill string and securing the vessel for transit, we departed Site $\mathrm{U} 1306$ at $0830 \mathrm{~h}$ on 28 October.

\section{Lithostratigraphy}

Four holes were drilled at Site U1306 (Table T1). All cores were recovered using the APC. The sediments at Site U1306 are dominated by varying mixtures of terrigenous components and biogenic material (primarily quartz, detrital carbonate, and nannofossils) (see "Site U1305 smear slides" in "Core Descriptions;" Fig. F5) so that the most common lithologies are silty clay, silty clay with diatoms, silty clay nannofossil ooze, and nannofossil silty clay. Burrowed and gradational contacts between these lithologies are much more common than well-defined or sharp boundaries. Abundances of terrigenous components, as estimated from smear slides, are quartz, 5\%-75\%; detrital carbonate, 0\%-95\%; feldspars, 0\%-5\%; clay minerals (including chlorite), 0\%-70\%; heavy minerals (especially hornblende), $0 \%-15 \%$; and volcanic glass, 0\%-5\%. Smear slides taken from interval 303U1306C-8H-1, 81-85 cm (71.12 meters composite depth [mcd]), and interval 303-U1306D-15H-4, 100$104 \mathrm{~cm}(146.83 \mathrm{mcd})$, have higher concentrations of volcanic ash. However, no distinct tephra layer was recognized in either case; instead, the higher abundance of volcanic ash appears to be present within burrow-filling sediment. Dropstones are common (at least one or more dropstones per core) throughout these cores (Fig. F6) and display a wide range of compositions, including acidic intrusive and metamorphic (granites, gneisses, and granitoids), basic igneous and/or metamorphic (basalts and metabasalts), and sedimentary and metasedimentary (sandstone and limestone) rocks. Abundances of biogenic components, as estimated from smear slides, are nannofossils, $0 \%-80 \%$; foraminifers, $0 \%-55 \%$; diatoms, 0\%-40\%; radiolarians, $0 \%-25 \%$; and sponge spicules, $0 \%-8 \%$. Total carbonate contents range from 0 to $12 \mathrm{wt} \%$ downhole (see "Geochemistry;" Table T24). Pyrite inclusions and burrows filled with pyritized sediment or surrounded by pyrite halos are abundant and constitute the only authigenic sediment components observed.

The sediments at Site U1306 are designated as a single lithostratigraphic unit, composed of Holoceneuppermost Pliocene (see "Biostratigraphy" and "Paleomagnetism") terrigenous and biogenic sediments, which are gradationally interbedded at scales of a few meters or less.

\section{Description of units}

\section{Unit I}

Intervals: Sections $303-\mathrm{U} 1306 \mathrm{~A}-1 \mathrm{H}-1,0 \mathrm{~cm}$, to $33 \mathrm{H}-\mathrm{CC}, 30 \mathrm{~cm}$; 303-U1306B-1H-1, $0 \mathrm{~cm}$, to $33 \mathrm{H}-\mathrm{CC}, 22 \mathrm{~cm}$; 303-U1306C-1H-1, $0 \mathrm{~cm}$, to 28H-CC, $28 \mathrm{~cm}$; and 303-U1306D-1H-1, 0 $\mathrm{cm}$, to $19 \mathrm{H}-\mathrm{CC}, 26 \mathrm{~cm}$

Depths: Hole U1306A: 0-307.0 mbsf, Hole U1306B: 0-315.9 mbsf, Hole U1306C: 0267.6 mbsf, and Hole U1306D: 0-179.5 mbsf (0-333.47 mcd)

Age: Holocene-Late Pliocene

Unit I is composed predominantly of silty clay and silty clay with diatoms. Nannofossil ooze with clay, silty clay nannofossil ooze, and silty clay with nannofossils; sandy clay, sandy clay with foraminifers, and clay are present as minor lithologies. Silty clay (with diatoms) is dark to very dark gray. Olive-brown sandy clay (with foraminifers), also defined as foraminifer ooze, is present in the uppermost $50 \mathrm{~cm}$ of Holes U1306A, U1306B, U1306C, and U1306D. This lithology is interpreted from smear slide data as the surface-oxidized equivalent of the underlying lithologies (Fig. F7). Other coarser-grained sediments are present as $\sim 10 \mathrm{~cm}$ thick layers of foraminifer sand, clayey sand, and sandy clay. These lithologies are rarely present downcore and are gray in color. Olivegray and/or greenish gray layers of clay or silty clay are present but rarely exceed $20 \mathrm{~cm}$ in thickness and are similar to the clay layers observed at Site U1305. These clay layers exhibit bioturbated boundaries and 
contain faint laminae of white silt. These greenish gray clay intervals are commonly burrow mottled, contain gravel or dropstones, and have a high detrital carbonate content (Figs. F8, F9).

All lithologies occur as horizontally bedded, mostly undisturbed sediments. The principal exception is drilling slurry, which typically occurs in the top section of each core and in core catchers. Disturbed intervals are rare and are observed only in intervals 303-U1306D-3H-5, 42-140 cm; 3H-7, 0-55 cm; 7H-3 and $7 \mathrm{H}-4,0-150 \mathrm{~cm} ; 7 \mathrm{H}-5,55-98 \mathrm{~cm} ; 7 \mathrm{H}-6,0-150$ $\mathrm{cm}$; $7 \mathrm{H}-\mathrm{CC}, 0-62 \mathrm{~cm}$; and Core $10 \mathrm{H}$. These intervals display deformed or flowed, sometimes faulted, structures. Some appear to be deformed mud clasts with variegated colors and irregular shapes (Figs. F10, F11). Some of these structures may be the result of deposition by debris flow or mass transport. However, coring disturbance is more likely because these features are present only in Hole U1306D, and the magnetic susceptibility (MS) data from Hole U1306D do not show any inconsistencies when compared to corresponding data from the three other holes. The sediment between the intervals specified above is undisturbed.

Dropstones are present in all four holes, and their distribution is plotted in Figure F6. Large dropstones $(>2 \mathrm{~cm})$ are common or abundant at this site (Fig. F12). Bioturbation is present throughout most of this unit; the most common indicators are diffuse centimeter-scale mottling and millimeter-scale burrows filled with pyrite concretions, white sand, foraminifer sand, or sponge spicules. In some cases, discrete burrows or macroscopic pyritized burrows were observed.

The silty clays at this site vary between dark gray (5Y 4/1) to very dark gray (5Y 3/1) and olive-gray (5Y 5/ 2 ). Intervals of silty clay with diatoms are very dark gray. Sandy clay and sandy clay with foraminifers (except for the surficial oxidized layers and foraminifer sand) are gray (5Y 5/1) to dark gray (5Y 4/1). Silty clay nannofossil ooze and nannofossil silty clay are gray, olive-gray, greenish gray (5GY 5/1), or dark greenish gray (5GY 4/1) and tend to have common to abundant bioturbation with pyritized burrows and dropstones. Contacts between these lithologies generally are gradational and commonly burrowed.

\section{Discussion}

The sediments at Site U1306 have biogenic and terrigenous components representing pelagic and hemipelagic deposition that have been modified by the interaction of bottom currents and topography on Eirik Drift. The resulting sediment composition reflects environmental changes that caused varia- tions in phytoplankton and zooplankton assemblages and production and discharge of icebergs.

Large-scale patterns in the distribution of important lithologies at Site U1306 are presented in Figure F13. Of the $1070 \mathrm{~m}$ recovered, $1027 \mathrm{~m}(96 \%)$ is silty clay or silty clay with diatoms. Silty clay nannofossil ooze and nannofossil silty clay compose $21.5 \mathrm{~m} \mathrm{(2 \% )}$ of the sediments, whereas nannofossil ooze composes $11 \mathrm{~m} \mathrm{(1 \% )}$ of the sediments. The remaining $10.5 \mathrm{~m}$ (1\%) consists of sandy clay, clayey sand, and foraminifer sand. The relative abundances of the major lithologies is remarkably consistent downcore.

Centimeter- to decimeter-scale beds of olive-gray (5Y $5 / 2$ ) or (dark) greenish gray (5GY $4 / 1$ and 5GY 5/1) clays or silty clays with high detrital carbonate are similar in appearance to detrital carbonate clay intervals identified at Site U1305 but are less common and thinner at Site U1306. However, the relationship between these olive/greenish gray detrital carbonate beds and the MS record is not straightforward.

Smear slides were taken at least once every two cores to document the composition of the dark gray silty clay that dominates these sediments. The quartz content of the sediment is less variable downcore than other components (Fig. F14). In contrast, both the detrital carbonate and the nannofossil contents are unusually low from 0 to 50 and from 150 to 250 mcd, respectively (except for a peak at $194 \mathrm{mcd}$ ). The foraminiferal abundance also decreases from abundant $(\sim 40 \%)$ to poor or barren below $150 \mathrm{mcd}$ (see "Biostratigraphy"). These low-carbonate intervals may be explained by dilution, dissolution, or low input. The preservation index for the coccolithophorids and planktonic foraminifers is moderate to good in these intervals, suggesting that dissolution is not a factor. The biostratigraphic and paleomagnetic age models do not show any major changes in sedimentation rates.

Gravel counts, defined as the number of clasts $>2$ $\mathrm{mm}$ in each $10 \mathrm{~cm}$ length of core, were made in all four holes, yielding a total of 632 clasts or 1.7 clast every $3 \mathrm{~m}$ of core. These abundances are too low to make meaningful interpretations about downcore variations. However, it is clear that the dropstones are present more frequently at Site U1306 than Site U1305 ( 1 dropstone/3 $\mathrm{m}$ of core). Deposition at these two sites is characterized by expanded interglacials at Site U1305, whereas Site U1306 has thicker glacial intervals. This model could explain the higher dropstone frequency at Site U1306. The granitic and basaltic dropstones are consistent with known source areas in east Greenland.

The lightness $\left(\mathrm{L}^{*}\right)$ of the color reflectance was measured every $2 \mathrm{~cm}$ in each undisturbed core section. 
$\mathrm{L}^{*}$ ranges between $25 \%$ and $50 \%$ at Site U1306; whereas $\mathrm{L}^{*}$ varies from $28 \%$ to $53 \%$ at Site U1305. This difference is ascribed to a lower average $\mathrm{CaCO}_{3}$ content at Site U1306 (3.2 wt\%) versus Site U1305 (12.3 wt\%) (see "Geochemistry"). For the interval between 40 and 150 mcd at Site U1306, $\mathrm{L}^{*}$ and MS show a strong inverse relationship such that higher $\mathrm{CaCO}_{3}$ imparts a light color and low MS to the sediments (Fig. F15). This relationship is less clear for the intervals $0-40$ mcd and below 150 mcd. $\mathrm{CaCO}_{3}$ content and abundances of calcareous nannofossils and planktonic foraminifers show significant decreases below $150 \mathrm{mcd}$. For the intervals between 0 and 40 mcd and below $150 \mathrm{mcd}, \mathrm{L}^{*}$ and MS may respond to the abundance of siliciclastic grains (Fig. F15) (Balsam et al., 1999).

\section{Biostratigraphy}

Micropaleontologic analysis of samples from Site U1306 reveals rich assemblages of calcareous, siliceous, and organic-walled microfossils. Coccoliths permit establishment of a biostratigraphic scheme that is complemented by a few datums from diatoms and planktonic foraminifers. According to this scheme, the composite sequence of Site U1306 covers an interval spanning about the last 2.2 m.y. (Fig. F16).

All microfossil groups are present but exhibit large variations in abundances downcore. Apart from the biostratigraphic scheme, the micropaleontologic assemblages also provide insight into the paleoceanographic conditions on the Erik Drift area. The dominant components of each microfossil group reflect cold sea-surface temperatures for most of the time during which the sedimentary sequence was deposited. Preservation is moderate to poor for all groups in the lower part of the sedimentary sequence (below 170 mcd). Reworked nannofossils and reworked palynomorphs of Cretaceous-Miocene age are present throughout the sequence at Site U1306.

\section{Calcareous nannofossils}

Calcareous nannofossils were examined in all core catcher samples from Holes U1306A-U1306D (Tables T2, T3, T4, T5). Nannofossils are generally abundant to few and rare to barren in some samples (Fig. F17). Preservation of nannofossils is mostly good to moderate (Fig. F18). Reworked nannofossils from the Cretaceous-Miocene are found throughout the sedimentary sequences of Site U1306. Some particular horizons have a high proportion of reworked nannofossils (e.g., Samples 303-U1306A-3H-CC, 303U1306B-1H-CC and 13H-CC, 303-U1306C-1H-CC, and $303-\mathrm{U} 1306 \mathrm{D}-5 \mathrm{H}-\mathrm{CC})$. About $50 \%$ of the assem- blage in Sample 303-U1306A-3H-CC comprises reworked nannofossils from the Upper Cretaceous. The nannofossil datums found at Site U1306 are listed in Tables T2, T3, T4, and T5. Biostratigraphic correlation among holes is shown in Figure F16. The first occurrence (FO) of Emiliania huxleyi, which defines the Zone NN21/NN20 boundary (0.25 Ma), is placed between Samples 303-U1306A-4H-CC and 5H-CC, 303-U1306B-3H-CC and 5H-CC, 303U1306C-4H-CC and 5-CC, and 303-U1306D-4H-CC and 5H-CC. The last occurrence (LO) of Pseudoemiliania lacunosa, which indicates the base of Zone NN20 (0.41 Ma), is present in Samples 303-U1306A8H-CC, 303-U1306B-8H-CC, 303-U1306C-8H-CC, and 303-U1306D-8H-CC. The LO of Reticulofenestra asanoi $(0.85 \mathrm{Ma})$, which is located just below the Brunhes Chron, is placed between Samples 303U1306A-14H-CC and 15H-CC, 303-U1306B-13H-CC and $15 \mathrm{H}-\mathrm{CC}, 303-\mathrm{U} 1306 \mathrm{C}-14 \mathrm{H}-\mathrm{CC}$ and $15 \mathrm{H}-\mathrm{CC}$, and 303-U1306D-14H-CC and 15H-CC. The FO of Gephyrocapsa parallela $(0.95 \mathrm{Ma})$ is correlated to the interval just above the Jaramillo Subchron of the Matuyama Chron and is found between Samples 303-U1306A-15H-CC and 16H-CC, 303-U1306B$15 \mathrm{H}-\mathrm{CC}$ and 17H-CC, 303-U1306C-15H-CC and 16H-CC, and 303-U1306D-15H-CC and 16H-CC. We therefore suggest an age spanning 0.85-0.95 Ma for the interval between 142 and 154 mcd (Fig. F16).

The sampled intervals 303-U1306A-16H-CC to $20 \mathrm{H}$ CC, 303-U1306B-16H-CC to 19H-CC, and 303U1306C-16H-CC to $19 \mathrm{H}-\mathrm{CC}$ are characterized by the presence of $R$. asanoi and the absence of G. parallela and are assigned to the age interval 0.95-1.16 Ma (the latter age is the FO of R. asanoi) (Fig. F16). Largesized specimens ( $>6 \mu \mathrm{m}$ ) of Gephyrocapsa spp. found in Samples 303-U1306A-22H-CC to 24H-CC, 303U1305B-20H-CC, and 303-U1306C-19H-CC to 20HCC (between 190 and $235 \mathrm{mcd}$ ), give an approximate age of 1.21-1.45 Ma (Fig. F16). The FO of Gephyrocapsa oceanica (1.65 Ma) is found between Samples 303-U1306A-26H-CC and 28H-CC, 303U1306B-26H-CC and 28H-CC, and 303-U1306C$24 \mathrm{H}-\mathrm{CC}$ and $26 \mathrm{H}-\mathrm{CC}$. The base of the Pleistocene, defined by the FO of Gephyrocapsa caribbeanica (1.73 $\mathrm{Ma})$, is recognized between Samples 303-U1306A$26 \mathrm{H}-\mathrm{CC}$ and 28H-CC, 303-U1306B-26H-CC and $28 \mathrm{H}-\mathrm{CC}$, and 303-U1306C-26H-CC and 27H-CC and is situated just above the Olduvai Subchron (Fig. F16). The assemblages found in samples below the above-mentioned datums are dominated by the presence of Coccolithus pelagicus, small-sized Reticulofenestra spp., P. lacunosa, and Calcidiscus macintyrei and by the absence of G. caribbeanica, G. oceanica, and Discoaster brouweri. This suggests that the lowermost core catcher samples at Site U1306 correspond to the uppermost Pliocene (1.97-1.73 Ma) (Fig. F16). 


\section{Planktonic foraminifers}

Planktonic foraminifers were examined in all core catcher samples from Holes U1306A-U1306D (Tables T6, T7, T8, T9). The majority of core catcher samples from each hole contain soft sediment that was washed with tap water. All samples below 303U1306A-D-18H-CC to 20H-CC, however, needed additional $\mathrm{H}_{2} \mathrm{O}_{2}$ treatment before washing. Planktonic foraminifers are mostly abundant to common within the upper half of all holes (Tables T6, T7, T8, T9). Samples 303-U1306D-8H-CC and 9H-CC contain planktonic foraminiferal sand. Below $175 \mathrm{mcd}$, many intervals are barren of planktonic foraminifers (Fig. F17). Preservation of tests is good to moderate in the upper half of the sedimentary sequence and mostly poor in the lower half (Fig. F17).

Encrusted Neogloboquadrina pachyderma (sinistral) is the most common taxon at Site U1306. The FO of encrusted $N$. pachyderma (sinistral), correlated to the top of the Olduvai Subchron (Weaver and Clement, 1987), occurs in Samples 303-U1306A-28H-CC and 303-U1306B-27H-CC. N. pachyderma (dextral) typically occurs with $2 \%-4 \%$ of the sinistrally coiled form. Globigerina bulloides and Turborotalita quinqueloba are occasionally present. These species are all present also in the modern North Atlantic. The presence of the extinct species Neogloboquadrina atlantica and Globigerina decoraperta in Samples 303-U1306A7H-CC and 303-U1306B-27H-CC, respectively, is probably a result of sediment reworking.

\section{Benthic foraminifers}

Benthic foraminifers were examined in all core catcher samples from Holes U1306A-U1306D (Table T10). Benthic foraminifers are abundant in the upper half of the succession. Many sections are barren of benthic foraminifers below $175 \mathrm{mcd}$. The specimen-rich benthic assemblages are characterized by small-sized species and juvenile specimens. Bolivina translucens is the most frequent species at Site U1306, and small-sized Cassidulina spp., Gavelinopsis praegeri, Melonis spp., and Pullenia spp. are abundant. A fragment of Stilostomella is found in Sample 303U1306A-28H-CC.

\section{Diatoms}

Diatom assemblages were investigated in 113 core catcher samples and 108 smear slides from Holes U1306A-U1306D (Tables T11, T12, T13, T14). Overall diatom abundance is mostly moderate to low below $\sim 180 \mathrm{mcd}$ and improves progressively above that depth (Fig. F17). Spores of Chaetoceros spp. are the main components of the sedimentary diatom assemblage, with other diatoms as secondary contributors representing different surface water conditions. The preservation of diatom valves varies strongly throughout the sedimentary sequence at Site U1306. The quality of preserved valves is mostly moderate between 290 and $337 \mathrm{mcd}$, poor between 245 and $290 \mathrm{mcd}$, and good to moderate above $245 \mathrm{mcd}$ (Tables T11, T12, T13, T14; Fig. F18). Three silicoflagellate species (Dictyocha fibula, Distephanus speculum, and Octactis pulchra) and the siliceous dinoflagellate Actiniscus pentasterias occur sporadically (Tables T11, T12, T13, T14). Sponge spicules were observed mostly in samples barren of diatoms and silicoflagellates.

Four Quaternary diatom zones proposed by Koç et al. (1999) are based on three primary diatom events (Fig. F16). The LO of Proboscia curvirostris, which defines the base of the Thalassiosira oestrupii Zone and the top of the P. curvirostris Zone (0.3 Ma, MIS 9; Koç et al., 1999), is located between Samples 303U1306A-5H-CC and 6H-CC, 303-U1306B-5H-CC and $6 \mathrm{H}-\mathrm{CC}$, and 303-U1306C-5H-CC and 6H-CC. The LO of Neodenticula seminae (0.84-0.85 Ma, MIS 21; Koç et al., 1999) appears between Samples 303-U1306A$13 \mathrm{H}-\mathrm{CC}$ and 14H-CC, 303-U1306B-14H-CC and 15H-CC, 303-U1306C-14H-CC and 15H-CC, and 303-U1306D-13H-CC and 14H-CC. The FO of $N$. seminae (1.25-1.26 Ma, MIS 37; Koç et al., 1999) occurs between Samples 303-U1306A-19H-CC and 20H-CC, 303-U1306B-19H-CC and 20H-CC, 303U1306C-19H-CC and 20H-CC, and in Sample 303U1306D-19H-CC. As a secondary datum, the FO of $P$. curvirostris (1.52-1.53 Ma; Koç et al., 1999) is tentatively identified in Samples 303-U1306A-23H-CC and $24 \mathrm{H}-\mathrm{CC}, 303-\mathrm{U} 1306 \mathrm{~B}-22 \mathrm{H}-\mathrm{CC}$ and $23 \mathrm{H}-\mathrm{CC}$, and 303-U1306C-22H-CC and 23H-CC.

A very diverse diatom flora occur downcore in the recovered sedimentary section ( 90 marine diatom species and a few freshwater diatoms were identified). The diatom assemblage is mostly dominated by Chaetoceros resting spores (Tables T11, T12, T13, T14). The high relative contribution of Chaetoceros spores at high latitudes reflects high productivity of surface waters (Crosta et al., 1997). The resting spore community is accompanied by several diatom species indicative of different ecological conditions. The main secondary assemblage, composed of spores and vegetative cells of Thalassiosira gravida, Actinocyclus curvatulus, Rhizosolenia hebetata f. semispina, and needle-shaped diatoms of the Thalassiothrix/Lioloma complex, is typical of subarctic and arctic waters (Andersen et al., 2004). Minor influence of warm and saline waters is mirrored by the presence of Coscinodiscus marginatus and varieties of $T$. oestrupii. The winter sea-ice-associated diatoms Fragilariopsis oceanica and Bacterosira fragilis are present in several samples (Monjanel and Baldauf, 1989). 


\section{Radiolarians}

Radiolarians were examined in all core catcher samples from Holes U1306A and U1306B. Radiolarians are generally common to rare (Table T15; Fig. F17). Species diversity is lower at Site U1306 than at Site U1305. Cycladophora davisiana davisiana is the dominant species throughout the sequences examined at Site U1306. Actinomma leptodermum occurs abundantly in the upper part of the holes (Table T15). Mostly moderately preserved radiolarians occur throughout the sedimentary sequences (Fig. F18). Since $C$. davisiana davisiana is present in all core catcher samples of Holes U1306A and U1306B, the sequences are assigned to the Late Pliocene-Pleistocene C. davisiana davisiana Zone of Goll and Bjørklund (1989).

\section{Palynomorphs}

Palynological assemblages were examined in all core catcher samples from Holes U1306A and U1306D (Tables T16, T17). All samples contain moderately well to well preserved palynomorphs. Dinocysts are present in variable numbers and are abundant only in a few samples (Fig. F17). Terrestrial palynomorphs, dominated by pollen grains of Pinus and Picea spp., occur in low numbers throughout the sequence at Site U1306. Reworked pre-Neogene palynomorphs are present almost throughout (Fig. F17) and are often common (Tables T16, T17). Microscopic fragments of charcoal are frequently observed in palynological slides.

The dinocyst assemblages are generally characterized by low concentrations and low species diversity. Abundant dinocysts are recorded in only a few samples in which Brigantedinium spp. is the dominant component (Tables T16, T17). Samples 303-U1306D$9 \mathrm{H}-\mathrm{CC}$ and $11 \mathrm{H}-\mathrm{CC}$ contain common dinocysts, and the assemblage is dominated by Operculodinium centrocarpum. Both Brigantedinium spp. and O. centrocarpum are among the most ubiquitous Pleistocene dinocyst taxa. Their dominance, the low dinocyst concentration, and the low species diversity suggest that the assemblages mostly reflect cold and/or lowsalinity surface waters.

The palynological assemblages contain a few species with biostratigraphic significance: Corrudinium? labradori with an LO at $\sim 0.4 \mathrm{Ma}$ and Filisphaera filifera and Cymatiosphaera ?invaginata with a North Atlantic LO at $\sim 0.7 \mathrm{Ma}$ (de Vernal et al., 1992). The presence of C.? labradori in Sample 303-U1306D-8H-CC suggests an age of $\sim 0.4 \mathrm{Ma}$ at $73 \mathrm{mcd}$, and the presence of F. filifera in Sample 19H-CC indicates the lowermost core catcher sample of this hole is older than 0.7 Ma.

\section{Paleomagnetism}

Natural remanent magnetization (NRM) of the archive-half core sections of all cores was measured before and after alternating-field (AF) demagnetization in a peak field of $10 \mathrm{mT}$. One or two additional steps of AF demagnetization were conducted for some core sections from Holes U1306A and U1306B. Core 303U1306A-13H and Sections 303-U1306A-22H-2 and $22 \mathrm{H}-3$ were demagnetized at AF peak fields of 10,15 , and $20 \mathrm{mT}$. Sections 303-U1306A-23H-3 to $24 \mathrm{H}-7$, 303-U1306A-25H-4 to 33H-7, and 303-U1306B-15H$2,15 \mathrm{H}-5,16 \mathrm{H}-1$ to $17 \mathrm{H}-3,17 \mathrm{H}-6$ to $17 \mathrm{H}-7,19 \mathrm{H}-2$, $22 \mathrm{H}-1$ to $27 \mathrm{H}-5,31 \mathrm{H}-4,31 \mathrm{H}-6$ to $31 \mathrm{H}-7$, and $32 \mathrm{H}-1$ to $33 \mathrm{H}-7$ were demagnetized at AF peak fields of 10 and $20 \mathrm{mT}$.

The magnetic intensities, inclinations, and declinations before and after AF demagnetization are shown in Figures F19, F20, and F21. Data associated with intervals identified as drilling slurry, disturbance, and exceptionally coarse grained deposits (see "Lithostratigraphy") were culled. Intensities of the $\mathrm{NRM}$ are in the $10^{-1}$ to $1 \mathrm{~A} / \mathrm{m}$ range for most intervals (Fig. F19). AF demagnetization at $10 \mathrm{mT}$ peak field significantly reduced the intensities. Further AF demagnetization up to $20 \mathrm{mT}$ peak field produced only minor changes (Fig. F19).

The polarities of the characteristic remanent magnetization (ChRM) were not discernible in the magnetic directions measured before AF demagnetization because of a magnetic overprint acquired during the coring process. ChRM became visible after AF demagnetization at peak field of $10 \mathrm{mT}$. Little difference is observed between the magnetic directions obtained at AF demagnetization of 10 and $20 \mathrm{mT}$, so most of the overprint and viscous magnetic components were removed by $10 \mathrm{mT}$ AF peak field demagnetization. Inclinations after AF demagnetization at $10 \mathrm{mT}$ peak field vary around the expected values $\left(\sim \pm 73^{\circ}\right)$ for a geocentric axial dipole (GAD) during normal and reversed polarity intervals. Declinations calculated with available Tensor-tool corrections are consistent with the polarity zones defined by inclinations. These results indicate that the ChRM is usually adequately defined after AF demagnetization at $10 \mathrm{mT}$ peak field. A few sections, particularly from the lower part of the sections, required additional AF demagnetization at peak field up to $20 \mathrm{mT}$ to clearly identify the polarity of their magnetization.

The four holes document an apparently continuous sequence including the Brunhes Chronozone and much of the Matuyama Chronozone. The Jaramillo, Cobb Mountain, and Olduvai Subchronozones are clearly identified. The lower Jaramillo polarity transition is truncated by a sand layer at a depth of $\sim 165$ 
mcd. The polarity transition near the base of Holes U1306A and U1306B at a depth of 311 mcd (Table T18) represents the base of the Olduvai Subchronozone. The Iceland Basin Event (Channell et al., 1997) is observed in sediments of Holes U1306A, U1306C, and U1306D at a depth of $\sim 32$ mcd in the Brunhes Chronozone. A short interval of normal polarity below the Cobb Mountain Subchronozone is tentatively interpreted as the Bjorn geomagnetic event previously identified at Ocean Drilling Program (ODP) Leg 162 Sites 983 and 984 (Channell et al., 2002). Tables T18 and T19 summarize the depths (mbsf and mcd) of the polarity transitions at Site U1306 and their correlation to the geomagnetic magnetic polarity timescale of Cande and Kent (1995).

\section{Composite section}

Cores were depth-shifted on the basis of MS, which proved to be the most useful parameter for correlating among holes at Site U1306. The high-amplitude variations in MS in the four holes drilled at Site U1306 permitted construction of a complete composite section for the last $2 \mathrm{~m}$.y. Features in MS are well aligned among holes, providing a continuous stratigraphic sequence to $\sim 337$ mcd (e.g., Fig. F22). The offsets and composite depths are listed in Table T20, and the sections of core used for the splice are identified in Table T21. We avoided using the first (top) section of each core because it was often disturbed. Below $\sim 287 \mathrm{mcd}$, cores were recovered in two holes only but the section is complete, with the possible exception of a tenuous tie between Cores 303U1306A-33H and 303-U1306B-33H near the base of the record (Fig. F22).

A growth factor (GF) of 1.08 was derived by linear regression for all holes at Site U1306, indicating an 8\% increase in mcd relative to mbsf (Fig. F23). We used this value of GF to calculate corrected meters composite depth ( $\mathrm{cmcd}$ ) presented in Table T20 to aid in the calculation of mass accumulation rates.

We calculated sedimentation rates using paleomagnetic and biostratigraphic datums (Table T22). Linear regression provides a mean sedimentation rate of $15.6 \mathrm{~cm} / \mathrm{k} . \mathrm{y}$. for the entire section cored at Site U1306 (Fig. F24). Interval sedimentation rates were calculated using paleomagnetic data only and varied between 12.4 and $19.3 \mathrm{~cm} /$ k.y. (Fig. F24).

In summary, stratigraphic correlation at Site U1306 provides a verifiably complete section for sediments deposited during the last 2 m.y. at relatively high rates of accumulation.

\section{Geochemistry}

\section{Volatile hydrocarbons}

Methane $\left(C_{1}\right)$ and ethane $\left(C_{2}\right)$ contents remaining in cores were measured using the headspace technique. The results are reported in Table T23 and Figure F25.

$\mathrm{C}_{1}$ concentrations gradually increase from 0 to 259 ppmv in the interval from 1.5 to $72 \mathrm{mcd}$ and increase rapidly to a maximum value of $42,644 \mathrm{ppmv}$ at $237 \mathrm{mcd}$. Ethane was detected below $133 \mathrm{mcd}$, ranging from 1.0 to a maximum value of $7.1 \mathrm{ppmv}$ at $290 \mathrm{mcd}$. No higher hydrocarbons were detected.

\section{Sedimentary geochemistry}

A total of 55 samples at a sampling resolution of two per core were collected for analysis of solid-phase geochemistry (inorganic carbon and elemental C, N, and $\mathrm{H}$ ) from Site U1306. Figure F26 shows calcium carbonate $\left(\mathrm{CaCO}_{3}\right)$ concentrations, total organic carbon (TOC) contents, total $\mathrm{N}$ concentrations, and organic $\mathrm{C} / \mathrm{N}$ ratios. Results of coulometric and elemental analyses are reported in Table T24.

$\mathrm{CaCO}_{3}$ contents for Site U1306 samples are extremely low, ranging from 0.3 to $12.3 \mathrm{wt} \%$ (average = $3.2 \mathrm{wt} \%$ ) (Fig. F26). TOC and total $\mathrm{N}$ contents at Site U1306 range from 0.1 to $1.1 \mathrm{wt} \%$ and from 0.03 to $0.10 \mathrm{wt} \%$, respectively (Fig. F26). The mean TOC and total $\mathrm{N}$ contents at Site U1306 are $\sim 0.3 \mathrm{wt} \%$ and $\sim 0.06 \mathrm{wt} \%$, respectively. TOC contents slightly increase downhole. No notable trend is recognized in downhole $\mathrm{N}$ records.

Most $\mathrm{C} / \mathrm{N}$ values are low (Fig. F26) and are in the range typical of fresh algal organic matter (4-10) (Meyers, 1997). The low $\mathrm{C} / \mathrm{N}$ values of $<4$ are probably an artifact of low TOC concentrations combined with the tendency of clay minerals to adsorb ammonium ions generated during degradation of organic matter (Müller, 1977).

\section{Interstitial water chemistry}

A total of 15 whole-round samples were collected from Hole U1306A for shipboard interstitial water (IW) geochemical analyses. In addition to wholeround samples, IWs were collected from small plug $\left(\sim 10 \mathrm{~cm}^{3}\right)$ sediment samples for the upper $\sim 100 \mathrm{mcd}$ for shore-based studies. Results of IW analyses for Site U1306 are reported in Table T25 and Figure F27.

\section{Chloride, sodium, $\mathrm{pH}$, and boron}

The chloride $\left(\mathrm{Cl}^{-}\right)$profile at Site U1306 exhibits an increasing downhole trend (Fig. F27). $\mathrm{Cl}^{-}$concentrations increase from $561 \mathrm{mM}$ in the shallowest sample $(1.5 \mathrm{mcd})$ to $581 \mathrm{mM}$ in the deepest sample at 
311 mcd. Pore fluid sodium $\left(\mathrm{Na}^{+}\right)$concentrations range from 440 to $496 \mathrm{mM}$. $\mathrm{Na}^{+}$concentrations increase downhole (Fig. F27) to a maximum of 496 $\mathrm{mM}$, and the $\mathrm{Na}^{+}$trend is similar to that of $\mathrm{Cl}^{-} . \mathrm{pH}$ values range from 7.0 to 7.7 with distinct fluctuations observed below 123 mcd (Fig. F27).

IW boron concentrations ranging from 411 to 559 $\mu \mathrm{M}$ are mostly higher than the seawater value of 427 $\mu \mathrm{M}$ (Fig. F27). The boron profile has two minima corresponding to $\mathrm{pH}$ maxima below $\sim 80$ mcd. Within the $\mathrm{pH}$ range of IW in this hole, boron exists mainly as boric acid $\left(\mathrm{H}_{3} \mathrm{BO}_{3}\right)$, as well as borate ions. Keren and Mezuman (1981) reported that $\mathrm{pH}$ and temperature affect adsorption of boron by clay minerals. The adsorption distribution factor of boron is controlled by $\mathrm{pH}$ (Xiao and Wang, 2001). High boron concentrations relative to seawater imply desorption of boron from clay and carbonate minerals. Because carbonate contents are very low throughout this hole (Fig. F26; Table T24), the pH dependency of boron adsorption and desorption from clay minerals is the most likely explanation of the antithetic trend between boron and $\mathrm{pH}$ in IWs.

\section{Alkalinity, sulfate, ammonium, and dissolved silica}

In the upper $\sim 92$ mcd at Site U1306, alkalinity increases steadily with depth from 3.9 to $18.7 \mathrm{mM}$ (Fig. F27), which reflects the effects of sulfate $\left(\mathrm{SO}_{4}{ }^{2-}\right)$ reduction and decomposition of organic matter. Below $157 \mathrm{mcd}$, alkalinity decreases progressively to 11.1 $\mathrm{mM}$ toward the base of the recovered section.

$\mathrm{SO}_{4}{ }^{2-}$ concentrations decrease downhole in the upper 92.3 mcd (Fig. F27). $\mathrm{SO}_{4}{ }^{2-}$ is almost depleted at 123 mcd. Interestingly, $\mathrm{SO}_{4}{ }^{2-}$ increases slightly between 157 and $280 \mathrm{mcd}$ to a maximum of $1.3 \mathrm{mM}$ at 217 mcd.

Ammonium $\left(\mathrm{NH}_{4}{ }^{+}\right)$steadily increases from $55 \mu \mathrm{M}$ at the surface to a maximum of $\sim 2000 \mu \mathrm{M}$ at the base of the hole. This suggests that the decomposition of organic matter and the resulting $\mathrm{NH}_{4}{ }^{+}$production persist below the $\mathrm{SO}_{4}{ }^{2-}$ reduction zone into the zone of methanogenesis (Fig. F27).

Dissolved silica $\left(\mathrm{H}_{4} \mathrm{SiO}_{4}\right)$ concentrations range from 488 to $945 \mu \mathrm{M}$ (Fig. F27). The downhole increasing $\mathrm{H}_{4} \mathrm{SiO}_{4}$ trend may reflect varying degrees of preservation and dissolution of biogenic $\mathrm{H}_{4} \mathrm{SiO}_{4}$ in the sediments (see "Biostratigraphy").

\section{Calcium, strontium, and lithium}

Calcium $\left(\mathrm{Ca}^{2+}\right)$ concentrations decrease downhole from seawater values in the shallowest sediment to a minimum of $3.7 \mathrm{mM}$ at $92 \mathrm{mcd}$ (Fig. F27). Below this depth, $\mathrm{Ca}^{2+}$ concentrations substantially increase with depth. The $\mathrm{Ca}^{2+}$ minimum is coincident with the alkalinity maximum at the sulfate/methane interface (SMI). Methane oxidation probably stimulates carbonate precipitation through production of alkalinity:

$$
\mathrm{CH}_{4}+\mathrm{SO}_{4}{ }^{2-} \rightarrow \mathrm{HCO}_{3}{ }^{-}+\mathrm{HS}^{-}+\mathrm{H}_{2} \mathrm{O}
$$

Strontium $\left(\mathrm{Sr}^{2+}\right)$ concentrations decrease with depth from the seafloor to a minimum of $66.5 \mu \mathrm{M}$ at 52 mcd, below which values increase to $95.2 \mu \mathrm{M}$ at the base of the hole (Fig. F27). The decrease in $\mathrm{Sr}^{2+}$, which is generally coincident with the minimum of $\mathrm{Ca}^{2+}$, suggests incorporation of $\mathrm{Sr}$ into a diagenetic carbonate phase. The lack of large increases in $\mathrm{Sr}^{2+}$ with depth indicates minimal dissolution or recystallization of biogenic carbonate within the cored interval.

Lithium $\left(\mathrm{Li}^{+}\right)$concentrations decrease with depth from the seafloor to a minimum of $14.1 \mu \mathrm{M}$ at 31 mcd. Consistently low $\mathrm{Li}^{+}$concentrations ranging from 14.1 to $15.8 \mu \mathrm{M}$ were observed between 31 and $123 \mathrm{mcd}$. These low $\mathrm{Li}^{+}$concentrations imply uptake of $\mathrm{Li}^{+}$into alteration products. Below 123 mcd, IW $\mathrm{Li}^{+}$concentrations increase steadily toward the bottom of the drilled sequence at Site U1306.

\section{Magnesium and potassium}

Magnesium $\left(\mathrm{Mg}^{2+}\right)$ concentrations gradually decrease from the seawater value of 52.7 to $36.3 \mathrm{mM}$ at the base of the hole (Fig. F27). Potassium $\left(\mathrm{K}^{+}\right)$concentrations monotonically decrease downcore to a minimum of $7.4 \mathrm{mM}$ at the base of the hole (Fig. F27).

The changes in $\mathrm{Mg}^{2+}$ and $\mathrm{K}^{+}$concentrations are highly correlated $\left(r^{2}=0.98\right)$ (Fig. F27), suggesting that both elements are being removed from pore waters by similar processes, most likely basement alteration and/or ion-exchange reactions associated with clay within or below the cored interval (Gieskes and Lawrence, 1981; De Carlo, 1992). Downhole decreases in $\mathrm{Mg}^{2+}$ and $\mathrm{K}^{+}$and increases in $\mathrm{Ca}^{2+}$ are consistent with silicate basement alteration shown in Gieskes and Lawrence (1981).

\section{Manganese, barium, and iron}

Higher manganese $\left(\mathrm{Mn}^{2+}\right)$ concentrations suggest $\mathrm{Mn}^{2+}$ reduction in the upper $41 \mathrm{mcd}(27-36 \mu \mathrm{M})$. $\mathrm{Mn}^{2+}$ concentrations decrease sharply down to 52 mcd and remain at low concentrations (6.3-15.6 $\mu \mathrm{M})$ to the base of the cored sequence at Site U1306 (Fig. F27).

IW barium $\left(\mathrm{Ba}^{2+}\right)$ concentrations are low $(0.1-0.5$ $\mu \mathrm{M}$ ) in the upper $62 \mathrm{mcd}$ (Fig. F27). At the base of the sulfate reduction zone, $\mathrm{Ba}^{2+}$ concentrations increase from 0.4 to $9.9 \mu \mathrm{M}$. Below $92 \mathrm{mcd}$ to the bottom of the section, $\mathrm{Ba}^{2+}$ concentrations remain rela- 
tively high (7.4-11.8 $\mu \mathrm{M})$. These higher $\mathrm{Ba}^{2+}$ concentrations are probably a consequence of Ba released from skeletal debris and ash as well as local dissolution of biogenic $\mathrm{BaSO}_{4}$ in reducing environments. Notable decreases of $\mathrm{Ba}^{2+}$ are recognized between 157 and 248 mcd. Because $\mathrm{SO}_{4}{ }^{2-}$ concentrations are elevated in the same depth range, these decreased $\mathrm{Ba}^{2+}$ concentrations result from remineralization or inhibited dissolution of barite (Fig. F27).

Iron $\left(\mathrm{Fe}^{2+}\right)$ is almost depleted in the uppermost sample. $\mathrm{Fe}^{2+}$ concentrations increase to a maximum of $24.4 \mu \mathrm{M}$ at $20 \mathrm{mcd}$ (Fig. F27). Below this maximum, $\mathrm{Fe}^{2+}$ concentrations are relatively constant, ranging from 12.0 to $15.8 \mu \mathrm{M}$ between 31 and $92 \mathrm{mcd}$. The low IW $\mathrm{Fe}^{2+}$ concentrations in the upper sediments indicate sequestration of dissolved ions into a solid phase (i.e., iron sulfides), which is commonly observed in the sediments (see "Lithostratigraphy").

$\mathrm{Fe}^{2+}$ concentrations fluctuate considerably below 92 mcd, with minima at 158 and 280 mcd. Interestingly, these $\mathrm{Fe}^{2+}$ variations are antithetic to $\mathrm{pH}$ fluctuations (Fig. F27). Furthermore, elevated $\mathrm{SO}_{4}{ }^{2-}$ and $\mathrm{Fe}^{2+}$ concentrations are both centered at $217 \mathrm{mcd}$, where intervals of pyrite are described in the cores (see "Lithostratigraphy"). These observations suggest the possibility of anaerobic oxidative dissolution of pyrite (Brothers et al., 1996):

$\mathrm{FeS}_{2}+14[\mathrm{Fe}-\mathrm{L}]^{+}+8 \mathrm{H}_{2} \mathrm{O} \rightarrow 15 \mathrm{Fe}^{2+}+12 \mathrm{HL}^{-}+2 \mathrm{H}_{2} \mathrm{~L}+2 \mathrm{SO}_{4}{ }^{2-}$, where $\mathrm{L}$ is any organic ligand. In this reaction, the more soluble ferric iron complexes come in contact with pyrite grains, causing oxidative dissolution, which in turn results in localized decreases in $\mathrm{pH}$. Low $\mathrm{CaCO}_{3}$ contents below 172 mcd could be associated with this lowered $\mathrm{pH}$.

\section{Physical properties}

Measurements of physical properties were conducted at Site U1306 following the procedures described in "Physical properties" in the "Site U1302-U1308 methods" chapter. Two measurements of MS were conducted, along with gamma ray attenuation (GRA) density, natural gamma radiation (NGR), and $P$-wave velocity. Moisture and density (MAD) properties were also measured on two discrete samples per core, usually at the bottom of Section 1 and top of Section 6 .

\section{Whole-core magnetic susceptibility measurements}

MS records produced during coring operations at Site U1306 are highly variable because of lithologic and/ or mineralogic changes. MS measurements obtained from the "Fast Track" multisensor core logger (MSCL) and the MST present the same trends and display multiple excursions toward higher values (Fig. F28). Site U1306 has peak MS values of $\sim 1200 \times$ $10^{-5}$ SI and minimum values of $200 \times 10^{-5}$, with most values ranging from $300 \times 10^{-5}$ to $900 \times 10^{-5} \mathrm{SI}$. The MS record is highly variable and contains a change in slope at $\sim 100 \mathrm{mcd}$ (Fig. F28). MS values increase from $300 \times 10^{-5}$ to $900 \times 10^{-5}$ from 0 to 100 mcd with an average value in this interval of $\sim 600 \times 10^{-5}$ SI. From 100 to $340 \mathrm{mcd}$, however, most MS values vary between $500 \times 10^{-5}$ and $900 \times 10^{-5}$ with an average value of $650 \times 10^{-5} \mathrm{SI}$.

\section{Density}

Bulk density measurements taken at Site U1306 show a similar trend among holes and are variable, ranging from 1.4 to $2.0 \mathrm{~g} / \mathrm{cm}^{3}$ (Fig. F29). The bulk density plots show a slope change at $\sim 100$ mcd that coincides with MS plots. Bulk density in the $0-100$ mcd interval averages $\sim 1.6 \mathrm{~g} / \mathrm{cm}^{3}$, whereas the lower interval (100-340 mcd) shows a higher average of $\sim 1.8 \mathrm{~g} / \mathrm{cm}^{3}$. Discrete density measurements were also determined from Hole U1306A physical property MAD samples. The discrete measurements match the values produced by the MST (Fig. F29).

\section{Natural gamma radiation}

NGR counts range from 8 to 35 cps with the majority of the values between 10 and 20 cps (Fig. F30). NGR values show a highly variable record that loosely correlates to the density record. NGR plots also show a change in slope at $\sim 100 \mathrm{mcd}$, which coincides with a change in slope in the MS and GRA records. NGR counts average $\sim 15 \mathrm{cps}$ from 0 to $120 \mathrm{mcd}$, whereas the average in the 100 to 340 mcd interval is $\sim 20$ cps.

\section{P-wave velocity}

Both $P$-wave logger (PWL) and discrete $P$-wave sensor number 3 (PWS3) measurements were performed at Site U1306 when possible. Because of the presence of methane gas, which disrupted velocity measurements, the velocity record is discontinuous and of poor quality. Measurements obtained at Site U1306 are fairly consistent, varying between 1500 and 1625 m/s (Fig. F31). We also see an offset between PWL and PWS3 measurements, which is a long-standing problem not unique to Expedition 303 (See "Physical properties" in the "Site U1302-U1308 methods" chapter).

\section{Porosity}

Porosity was calculated using MST GRA density measurements and spot checked with the porosity results generated from MAD samples. Porosity values are highly variable and range from $40 \%$ to $80 \%$ (Fig. 
F32). As expected, porosity shows an inverse relationship to density. Porosity decreases with depth at Site U1306 to an average minimum value of 50\%, which may be attributed to the compaction of sediments with depth.

\section{Discussion}

MS values at Site U1306 are higher than those at Site U1305, averaging $626 \times 10^{-5}$ and $436 \times 10^{-5} \mathrm{SI}$, respectively (Fig. F33). Site U1305 has an average carbonate content of $12.3 \mathrm{wt} \%$, whereas Site U1306 has an average carbonate content of $\sim 3.2 \quad$ wt $\%$ (see "Geochemistry"). Hence, we suggest that the carbonate content of the sediments is an important control on MS values at Sites U1305 and U1306.

The MS records three intervals of broad change at Site U1306 that may be linked to the carbonate content of the sediments (Fig. F33). The first interval from 0 to 100 mcd (Fig. F33) contains MS values that average $603 \times 10^{-5}$ SI in an interval with relatively high carbonate content (see "Geochemistry"). This upper interval is also characterized by high-frequency, high-amplitude variability of MS in the interval from $\sim 50$ to $100 \mathrm{mcd}$, whereas the interval from 0 to $50 \mathrm{mcd}$ is characterized by high-frequency, low-amplitude variability. This pattern of variability is also apparent in the carbonate data. The second broad change is apparent from 120 to 220 mcd (Fig. F33), where MS values increase to a mean value of $\sim 646 \times 10^{-5}$ and the carbonate content decreases. The lowermost interval between 220 and $340 \mathrm{mcd}$ is characterized by lower MS values, averaging $618 \times$ $10^{-5}$, and higher carbonate values. Although the uppermost sections of Site U1306 show a clear relationship between changes in carbonate content and variability within the MS record, some intervals cannot be explained by this relationship. Further shorebased research must be conducted to completely understand the variability contained within the MS record.

GRA density is highly variable with an increasing trend downcore, probably because of compaction of the sediments (Fig. F33). There is a greater rate of increase for sediments between 0 and 100 mcd than for sediments between 100 and $340 \mathrm{mcd}$. We assume the greater rate of change in density is related to the higher carbonate content in this interval coupled with the normal increase in compaction with depth.

NGR generally mimics the GRA record at Site U1306 (Fig. F33). However, NGR does not show any clear relationship with the MS records. NGR also shows a discontinuity at $\sim 100$ mcd in which the sediments between 0 to 100 mcd have lower values, high variability, and lower amplitudes, whereas the sediments between 100 and 340 mcd have higher values, high variability, and higher amplitudes. We attribute this discontinuity in the record to the presence of higher carbonate content between 0 and 100 mcd.

One of the major objectives of Expedition 303 is to investigate millennial-scale variability beyond the reach of conventional piston coring. The high-resolution MS, NGR, and GRA records capture variability on this timescale. There are intervals at Site U1306 where the MS, NGR, and GRA records covary, and there are many intervals where the MS appears to lag or be antithetic to the GRA and NGR records, indicating a complex depositional history. Shore-based analyses are required to fully understand the causes of the variability within the physical property records and their relationship to climate change.

\section{References}

Andersen, C., Koç, N., and Moros, M., 2004. A highly unstable Holocene climate in the subpolar North Atlantic: evidence from diatoms. Quat. Sci. Rev., 23:21552166. doi:10.1016/j.quascirev.2004.08.004

Balsam, W.L., Deaton, B.C., and Damuth, J.E., 1999. Evaluating optical lightness as a proxy for carbonate content in marine sediment cores. Mar. Geol., 161:141-153. doi:10.1016/S0025-3227(98)00037-7

Brothers, L.A., Engel, M.H., and Elmore, R.D., 1996. The late diagenetic conversion of pyrite to magnetite by organically complexed ferric iron. Chem. Geol., 130:114.

Cande, S.C., and Kent, D.V., 1995. Revised calibration of the geomagnetic polarity timescale for the Late Cretaceous and Cenozoic. J. Geophys. Res., 100:6093-6095. doi:10.1029/94JB03098

Channell, J.E.T., Hodell, D.A., and Lehman, B., 1997. Relative geomagnetic paleointensity and $\delta^{18} \mathrm{O}$ at ODP Site 983 (Gardar Drift, North Atlantic) since $350 \mathrm{ka}$. Earth Planet. Sci. Lett., 153:103-118. doi:10.1016/S0012821X(97)00164-7

Channell, J.E.T., Mazaud, A., Sullivan, P., Turner, S., and Raymo, M.E., 2002. Geomagnetic excursions and paleointensities in the Matuyama Chron at ODP Sites 983 and 984 (Iceland Basin). J. Geophys. Res., 107. doi:10.1029/2001JB000491

Cremer, M., 1989. Texture and microstructure of NeogeneQuaternary sediments, ODP Sites 645 and 646, Baffin Bay and Labrador Sea. In Srivastava, S.P., Arthur, M.A., Clement, B., et al., Proc. ODP, Sci. Results, 105: College Station, TX (Ocean Drilling Program), 7-20.

Crosta, X., Pichon, J.-J., and Labracherie, M., 1997. Distribution of Chaetoceros resting spores in modern peri-Antarctic sediments. Mar. Micropaleontol., 29:283-299. doi:10.1016/S0377-8398(96)00033-3

de Vernal, A., Londeix, L., Mudie, P.J., Harland, R., Morzadec-Kerfourn, M.T., Turon, J.-L., and Wrenn, J.H., 1992. Quaternary organic-walled dinoflagellate cysts of the North Atlantic Ocean and adjacent seas: ecostratigraphy and biostratigraphy. In Head, M.J., and Wrenn, J.H. 
(Eds.), Neogene and Quaternary Dinoflagellate Cysts and Arcritarchs: Salt Lake City (Publisher's Press), 289-328.

Gieskes, J.M., and Lawrence, J.R., 1981. Alteration of volcanic matter in deep-sea sediments: evidence from the chemical composition of interstitial waters from deep sea drilling cores. Geochim. Cosmochim. Acta, 45:16871703.

Goll, R.M., and Bjørklund, K.R., 1989. A new radiolarian biostratigraphy for the Neogene of the Norwegian Sea: ODP Leg 104. In Eldholm, O., Thiede, J., Taylor, E., et al., Proc. ODP, Sci. Results, 104: College Station, TX (Ocean Drilling Program), 697-737. [PDF]

Hillaire-Marcel, C., and Bilodeau, G., 2000. Instabilities in the Labrador Sea water mass structure during the last climatic cycle. Can. J. Earth Sci., 37:795-809. doi:10.1139/cjes-37-5-795

Hillaire-Marcel, C., de Vernal, A., Bilodeau, G., and Wu, G., 1994. Isotope stratigraphy, sedimentation rates, deep circulation, and carbonate events in the Labrador Sea during the last $200 \mathrm{ka}$. Can. J. Earth Sci., 31:63-89.

Hiscott, R.N., Cremer, M., and Aksu, A.E., 1989. Evidence from sedimentary structures for processes of sediment transport and deposition during post-Miocene time at Sites 645, 646, and 647, Baffin Bay and the Labrador Sea. In Srivastava, S.P., Arthur, M.A., Clement, B., et al., Proc. ODP, Sci. Results, 105: College Station, TX (Ocean Drilling Program), 53-63. [PDF]

Keren, R., and Mezuman, V., 1981. Boron adsorption by clay minerals using a phenomenological equation. Clays Clay Miner., 29:198-204.

Koç, N., Hodell, D.A., Kleiven, H., and Labeyrie, L., 1999. High-resolution Pleistocene diatom biostratigraphy of Site 983 and correlations with isotope stratigraphy. In Raymo, M.E., Jansen, E., Blum, P., and Herbert, T.D. (Eds.), 1999. Proc. ODP, Sci. Results, 162: College Station, TX (Ocean Drilling Program), 51-62. [HTML]

Meyers, P.A., 1997. Organic geochemical proxies of paleoceanographic, paleolimnologic, and paleoclimatic processes. Org. Geochem., 27:213-250. doi:10.1016/S01466380(97)00049-1

Monjanel, A.-L., and Baldauf, J.G., 1989. Miocene to Holocene diatom biostratigraphy from Baffin Bay and Labrador Sea, Ocean Drilling Program Sites 645-646. In
Srivastava, S.P., Arthur, M.A., Clement, B., et al., Proc. ODP, Sci. Results, 105: College Station, TX (Ocean Drilling Program), 305-322. [PDF]

Müller, P.J., 1977. C/N ratios in Pacific deep sea sediments: effect of inorganic ammonium and organic nitrogen compounds sorbed by clays. Geochim. Cosmochim. Acta, 41:765-776.

Sato, T., Kameo, K., and Mita, I., 1999. Validity of the latest Cenozoic calcareous nannofossil datums and its application to the tephrochronology. Earth Sci., 53:265-274.

Smith, W.H.F., and Sandwell, D.T., 1994. Bathymetry prediction from dense satellite altimetry and sparse shipboard bathymetry. J. Geophys. Res., 99:21803-21824. doi:10.1029/94JB00988

Stoner, J.S., Channell, J.E.T., and Hillaire-Marcel, C., 1995. Late Pleistocene relative geomagnetic paleointensity from the deep Labrador Sea: regional and global correlations. Earth Planet. Sci. Lett., 134:237-252. doi:10.1016/ 0012-821X(95)00134-X

Stoner, J.S., Channell, J.E.T., and Hillaire-Marcel, C., 1998. A 200 ka geomagnetic chronostratigraphy for the Labrador Sea: indirect correlation of the sediment record to SPECMAP. Earth Planet. Sci. Lett., 159:165-181. doi:10.1016/S0012-821X(98)00069-7

Turon, J.-L., Hillaire-Marcel, C., and Shipboard Participants, 1999. IMAGES V mission of the Marion Dufresne, Leg 2, 30 June to 24 July 1999. Geol. Surv. Canada, Open File 3782 .

Weaver, P.P.E., and Clement, B.M., 1987. Magnetobiostratigraphy of planktonic foraminiferal datums, DSDP Leg 94, North Atlantic. In Ruddiman, W.F., Kidd, R.B., Thomas, E., et al., Init. Repts. DSDP, 94: Washington (U.S. Govt. Printing Office), 815-829.

Wei, W., 1993. Calibration of upper Pliocene-lower Pleistocene nannofossil events with oxygen isotope stratigraphy. Paleoceanography, 8:85-99.

Xiao, Y., and Wang, L., 2001. The effect of $\mathrm{pH}$ and temperature on the isotopic fractionation of boron between saline brine and sediments. Chem. Geol., 171:253-261.

Publication: 9 September 2006 MS 303ER-106 
Figure F1. Location of Site U1306 relative to Sites U1305 and U1307, ODP Site 646, and piston core HU90013-012 (P-012). Bathymetry from Smith and Sandwell (1994).
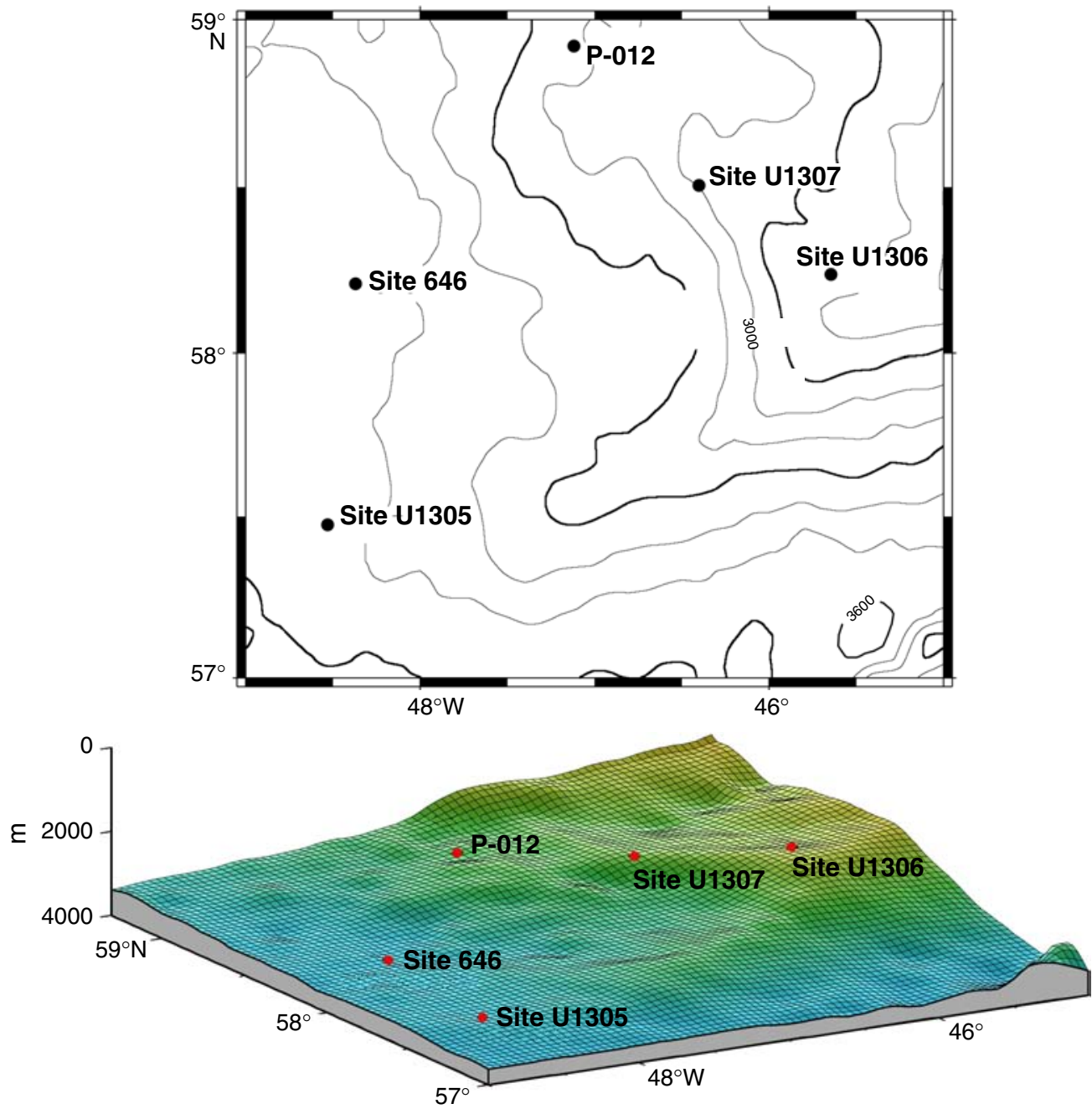
Figure F2. Multisensor track whole-core and discrete sample volumetric magnetic susceptibility of MD992228 and MD99-2242 (Turon et al., 1999) compared with the discrete sample volumetric magnetic susceptibility for HU90-013-012 (Stoner et al., 1995, 1998). Lines with arrows are used to indicate correlative features within the susceptibility records. Differences in the depths of correlative features are attributed to core stretching, particularly in the Marion-Dufresne (MD) cores.

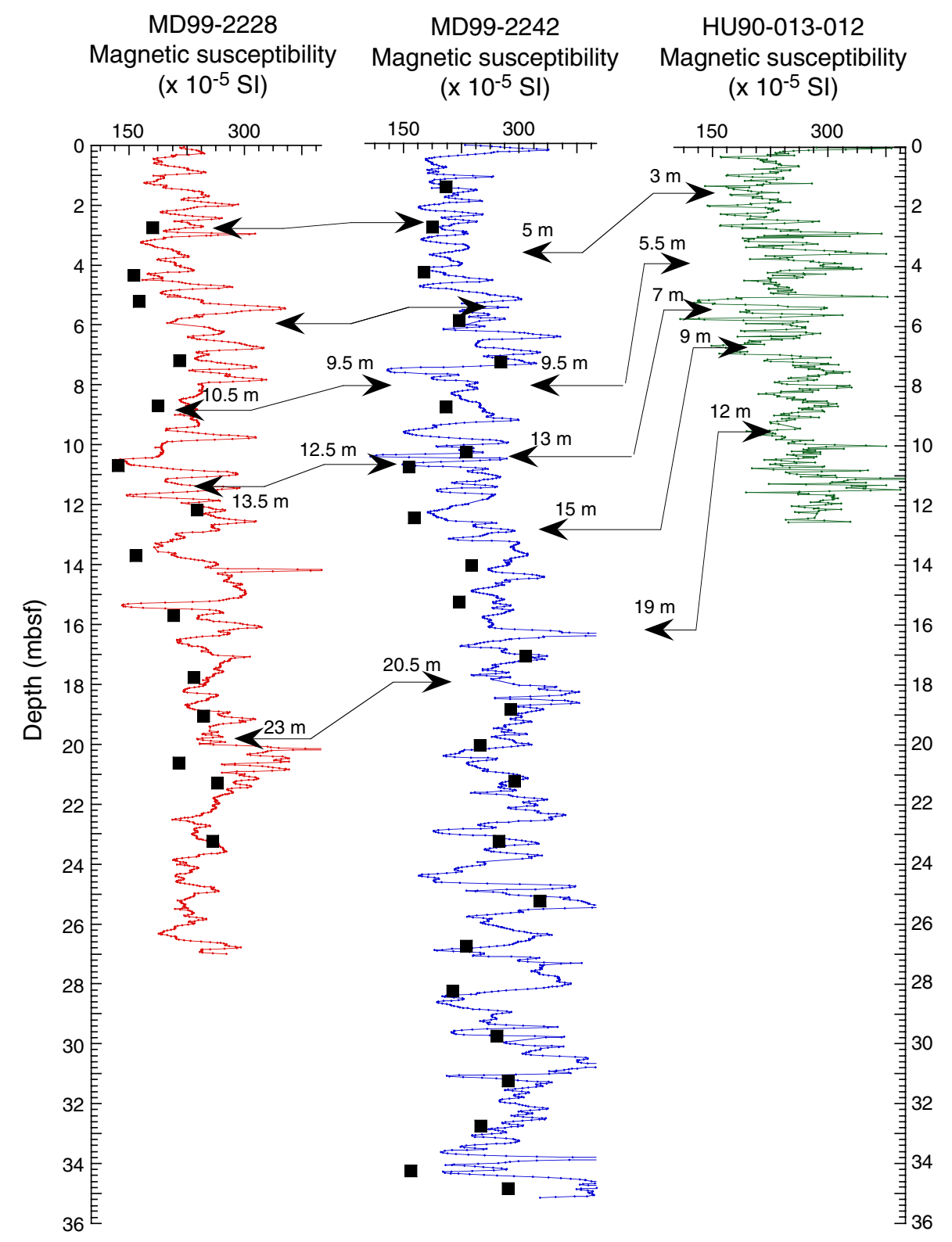


Figure F3. Multichannel seismic record across Site U1306 obtained along seismic Lines 19 and 24c during cruise KN166-14. The location of the R1 seismic reflector, correlated to the mid-Upper Pliocene at ODP Site 646, and the estimated (actual) penetration at Site U1306 (base of Quaternary) are indicated. CDP $=$ common depth point (Mountain et al., unpubl. data).
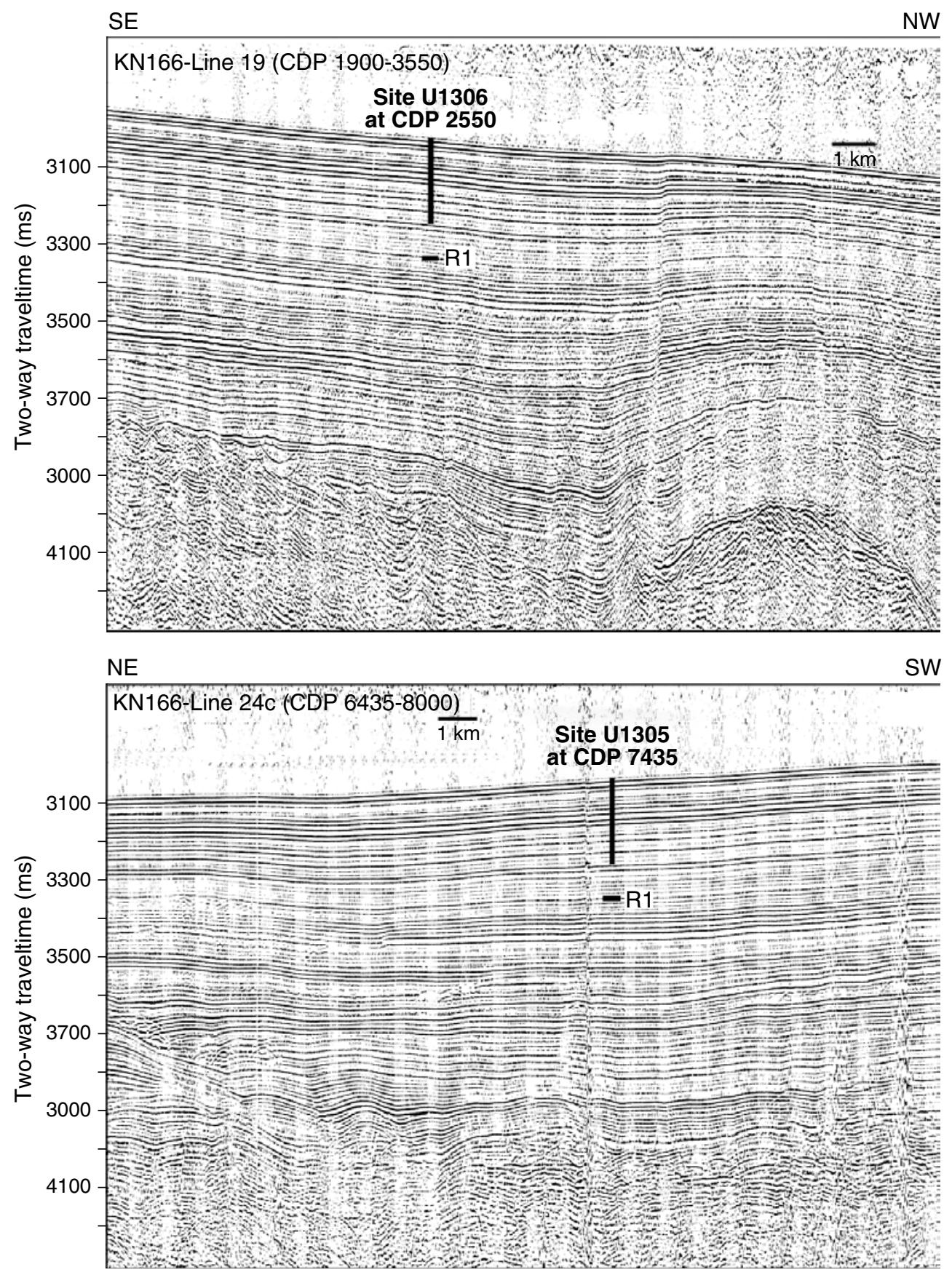
Figure F4. $3.5 \mathrm{kHz}$ data at Site U1306 obtained from seismic Line 19 during Knorr cruise KN166-14 (Mountain et al., unpubl. data).

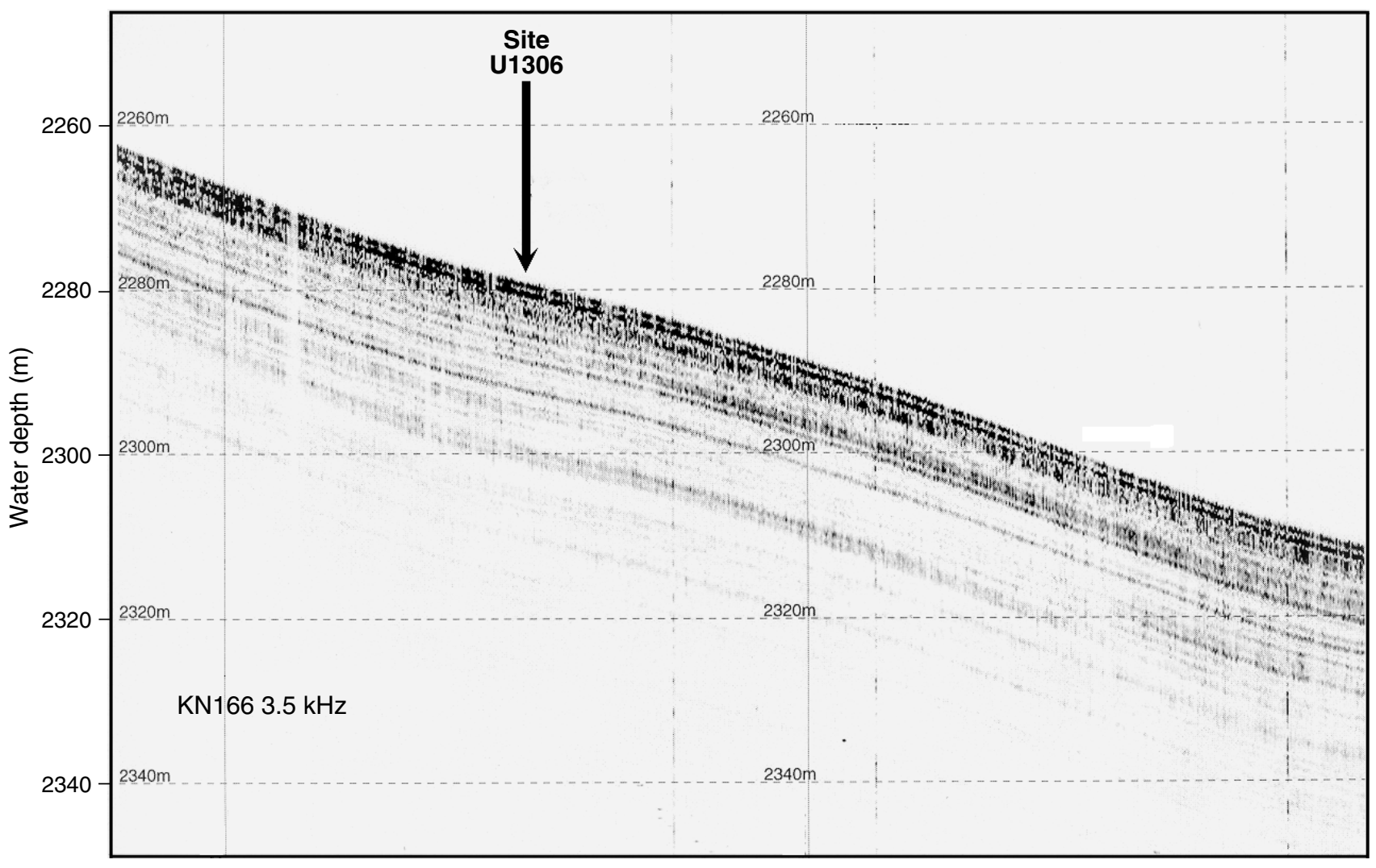


Figure F5. Abundances of quartz, detrital carbonate, nannofossils, and foraminifers. Black circles = Hole U1306A data, blue squares $=$ Hole U1306B data, open red circles $=$ Hole U1306C data, open green squares = Hole U1306D data.

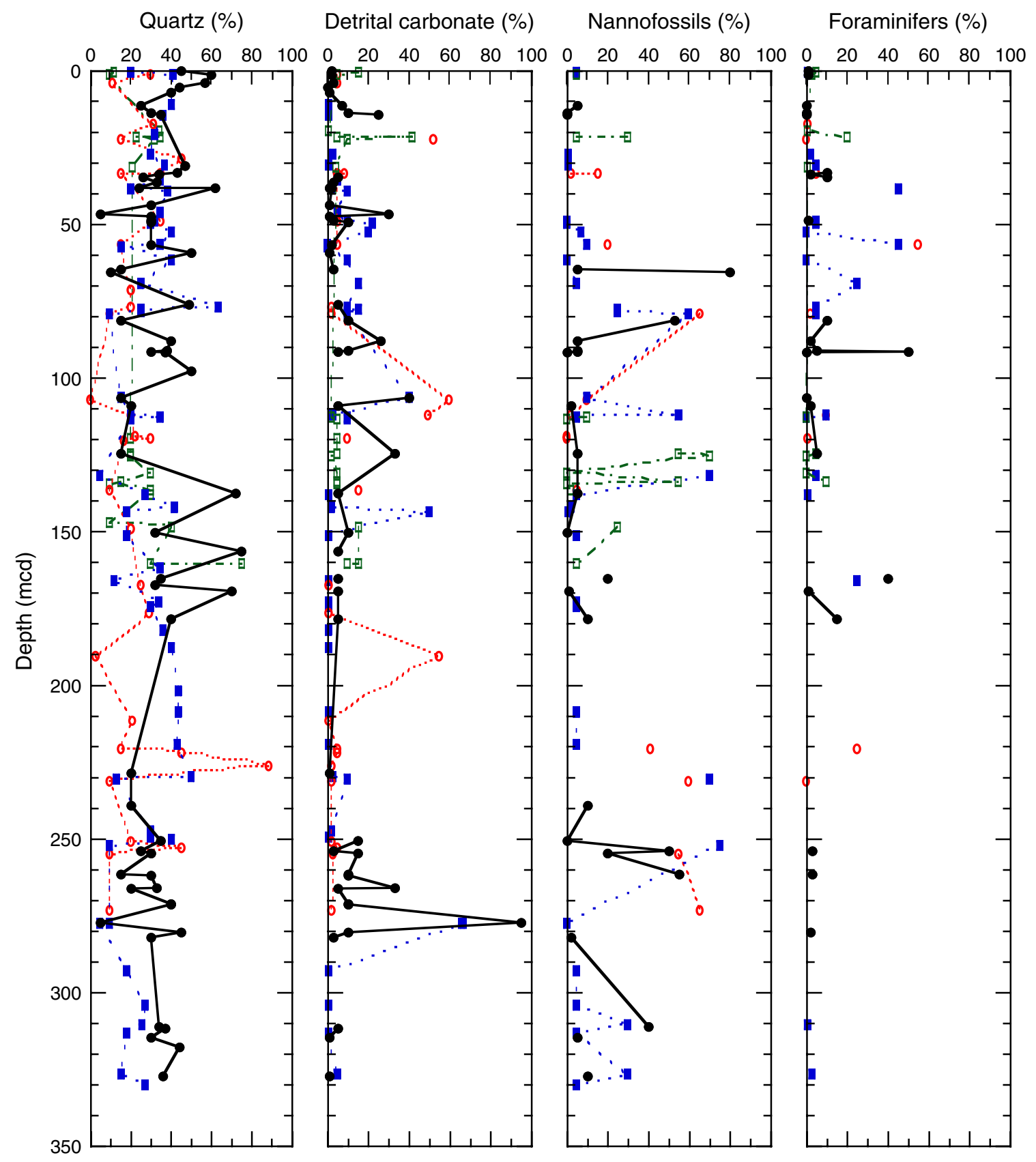


Figure F6. Abundance of gravel-sized grains (number of grains $/ 10 \mathrm{~cm}$ length of core).

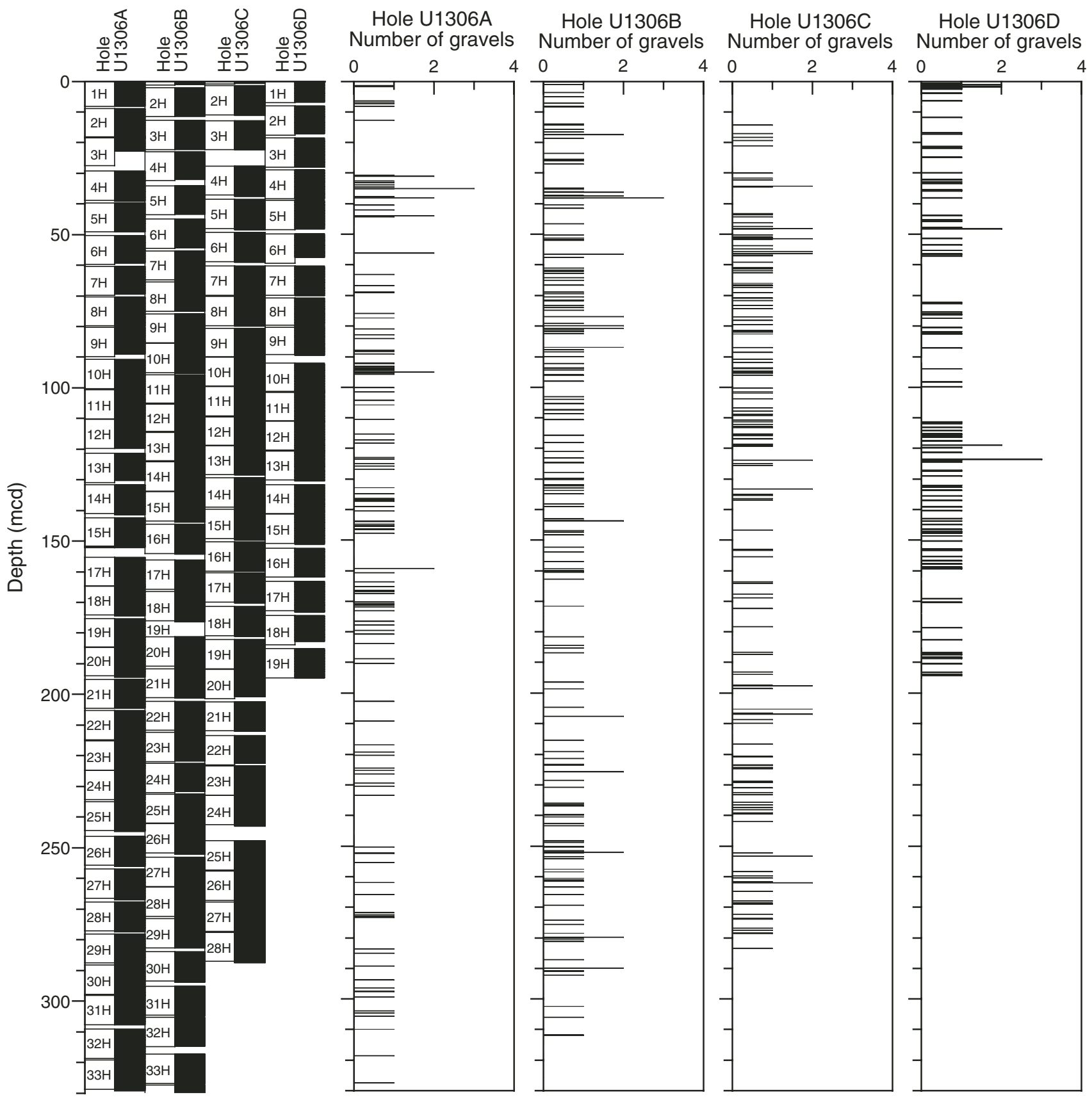


Figure F7. Oxidized layer at top of Unit I (interval 303-U1306B-1H-1, 0-20 cm).

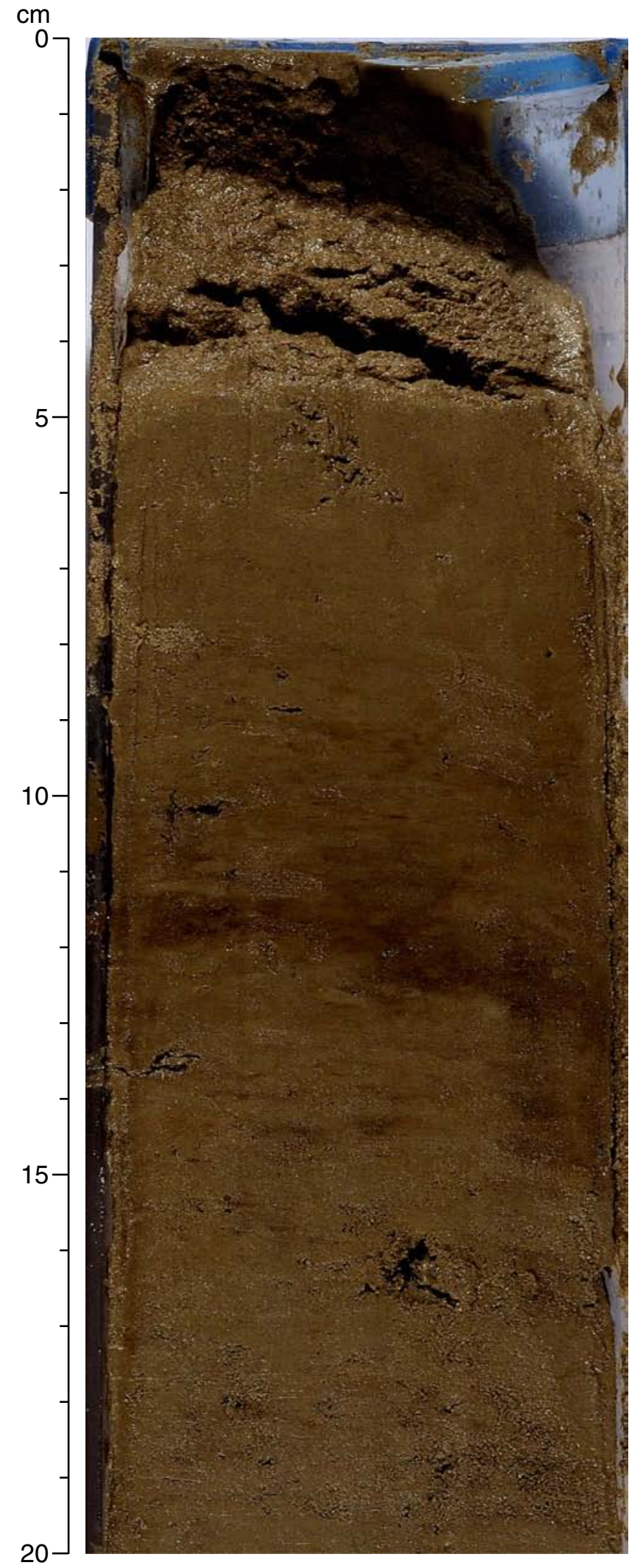


Figure F8. Detrital carbonate layer, showing bioturbated/irregular contacts. Note faint white silt laminae (interval 303-U1306A-28H-8, 40-60 cm).

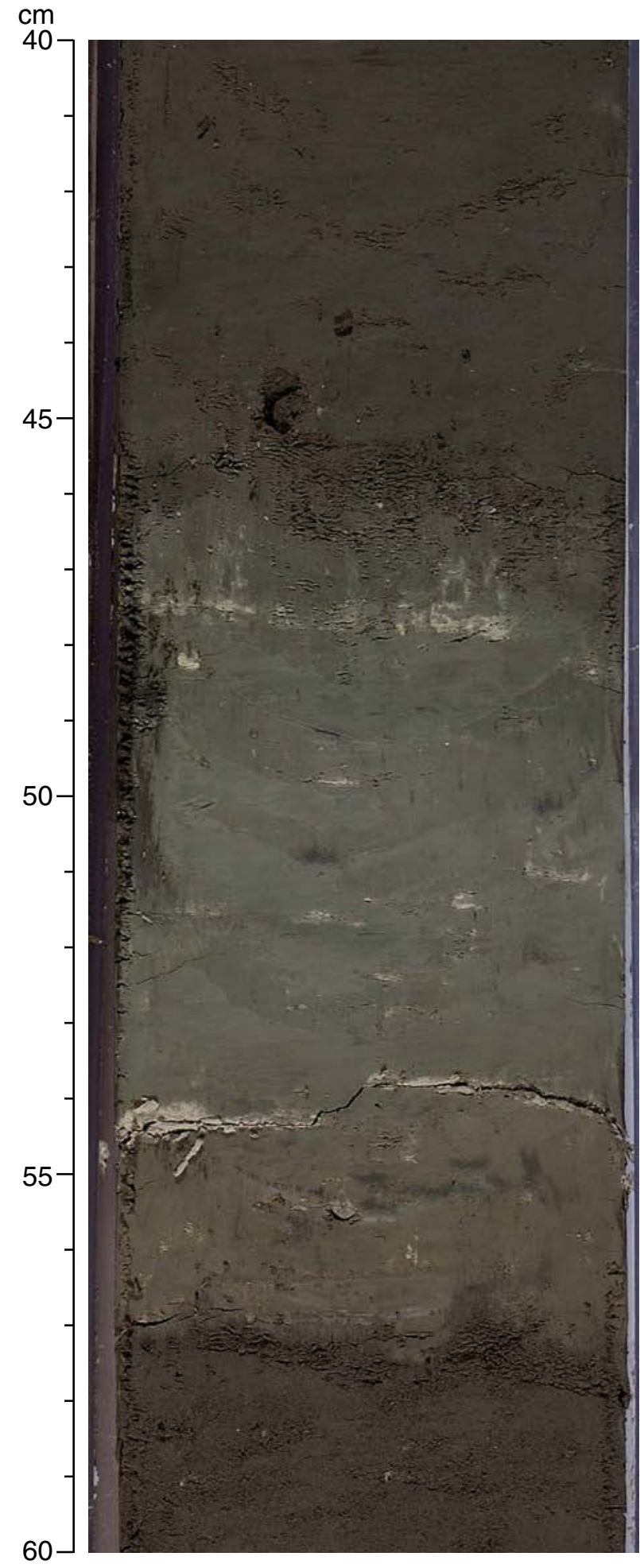


Figure F9. Detrital carbonate layer, showing bioturbated/irregular contacts. Note faint white silt laminae (interval 303-U1306B-4H-2, 88-120 cm).

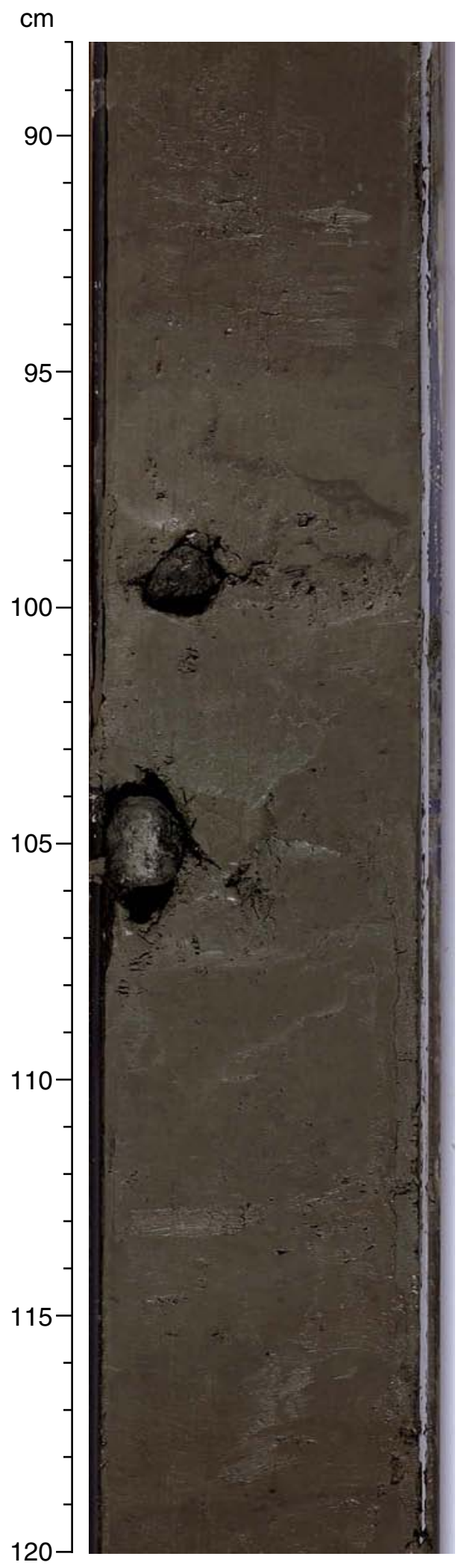


Figure F10. Disturbed core interval showing lithologies with variegated sediment color, and irregular shaped layers and faults (interval 303-U1306D-3H-5, 130-150 cm).

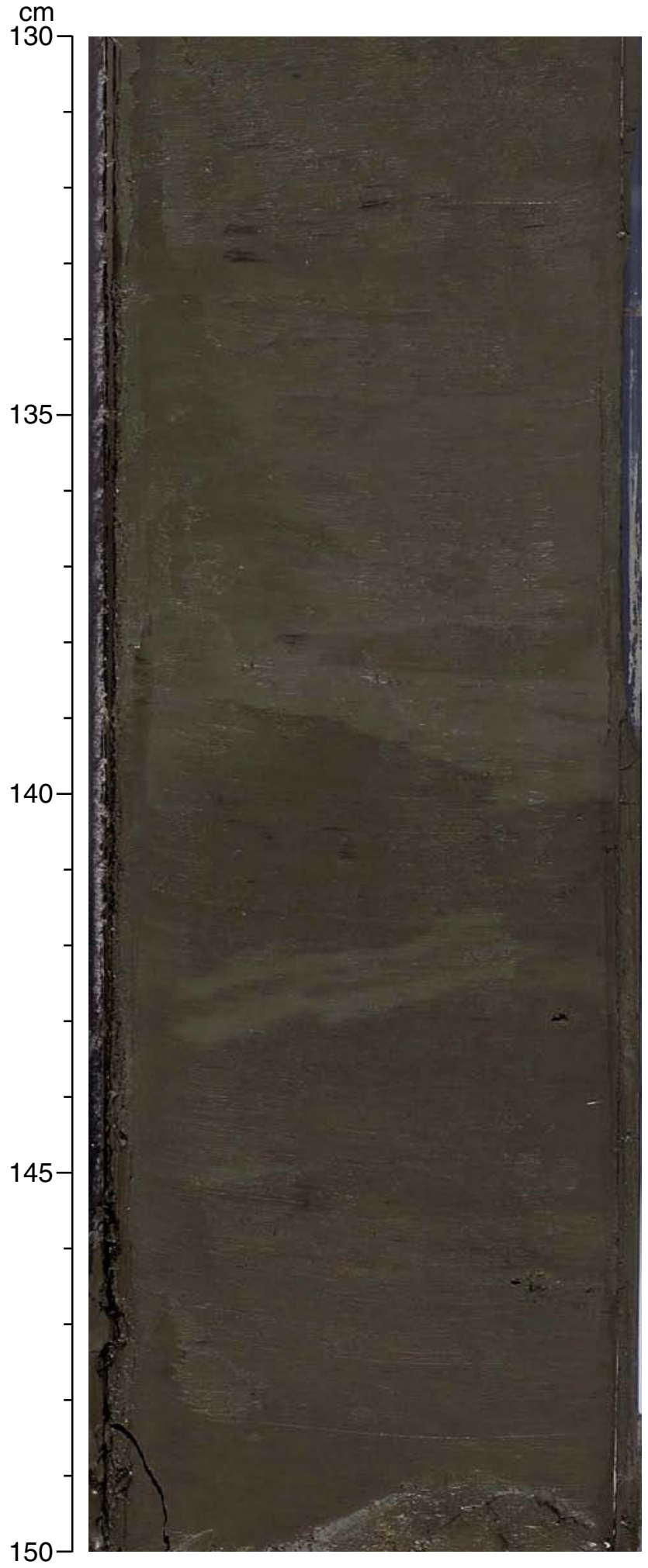


Figure F11. Disturbed core interval showing lithologies with variegated sediment colors and irregular shaped layers and faults (interval 303-U1306D-7H-4, 17-48 cm).

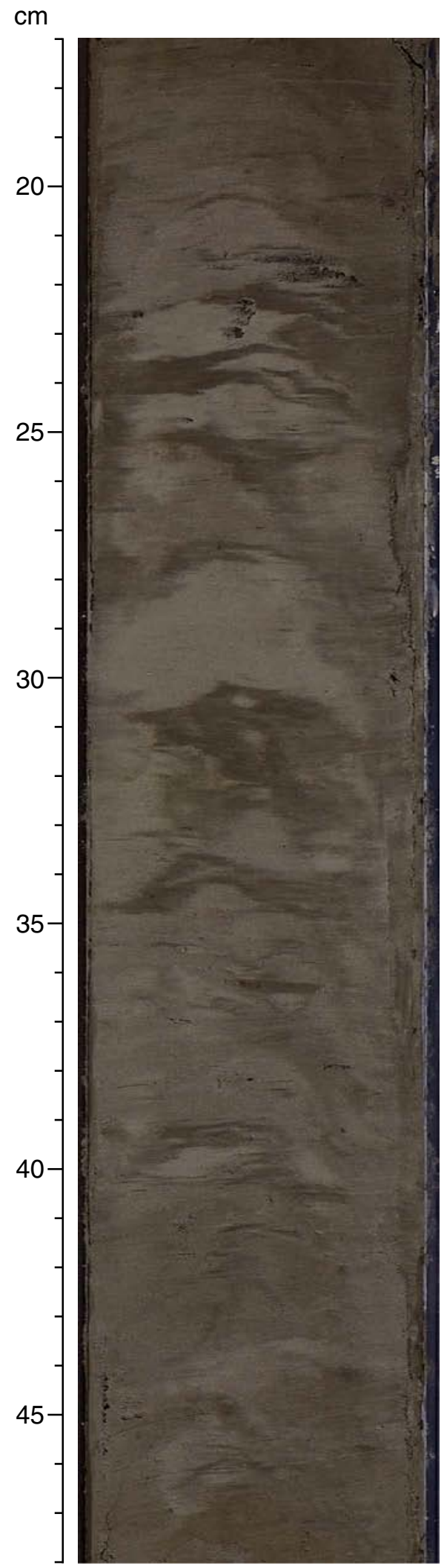


Figure F12. Cobble-sized dropstones (interval 303-U1306B-15H-3, 102-125 cm).

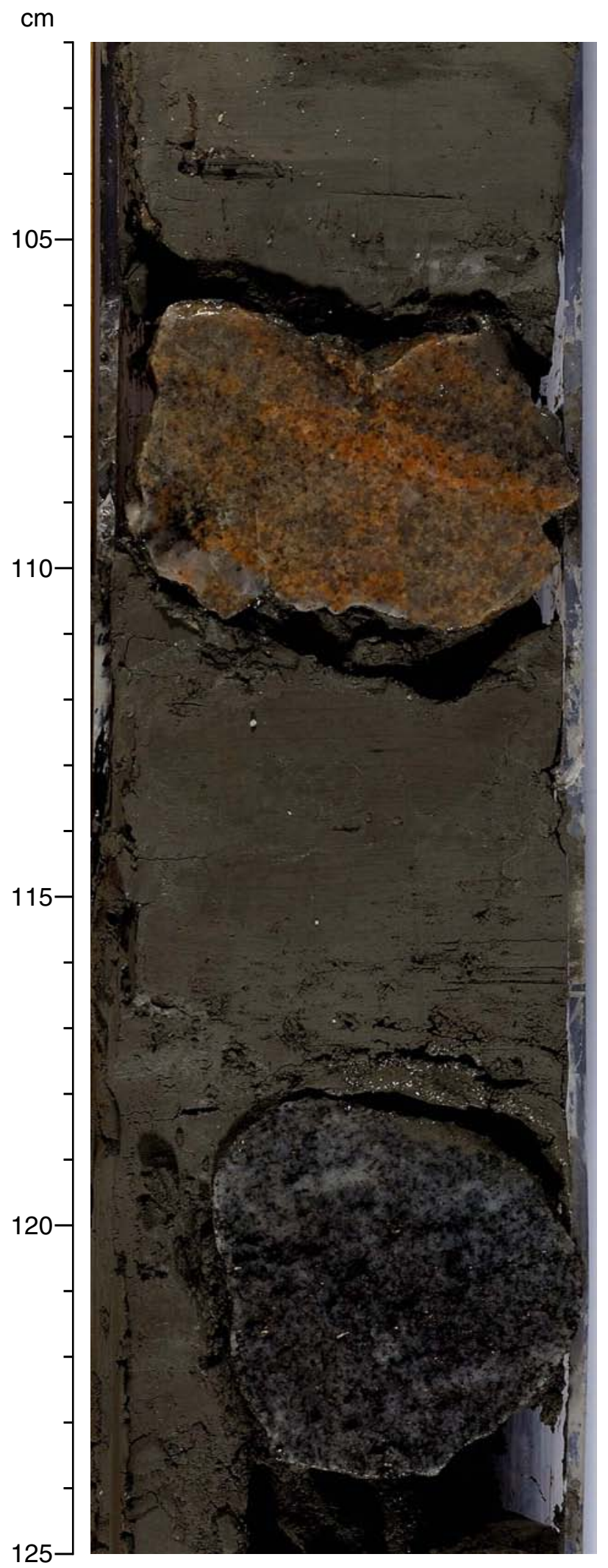


Figure F13. Graphic summary of the lithologies recovered at Site U1306.

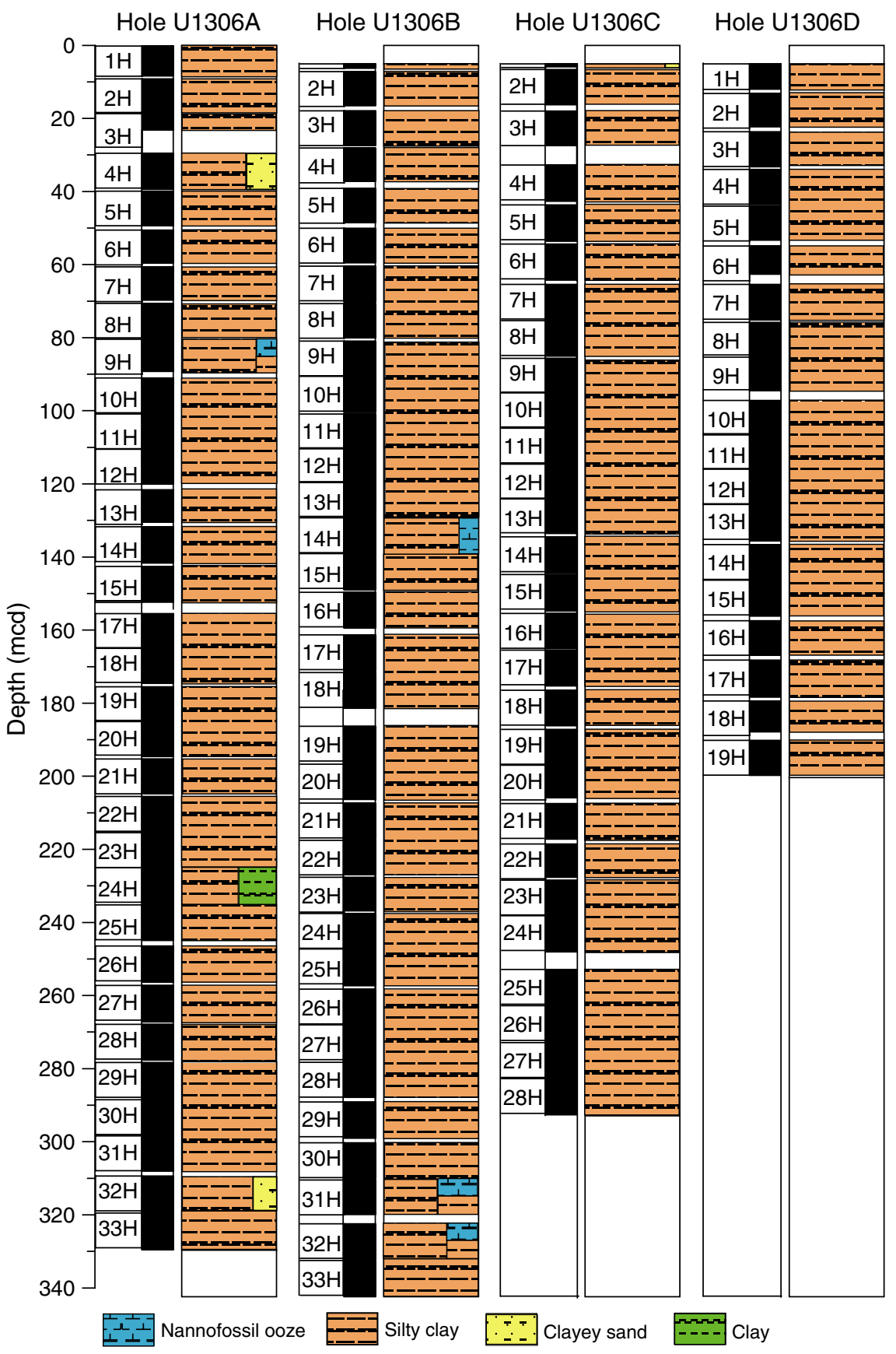


Figure F14. Color reflectance lightness $\left(\mathrm{L}^{*}\right)$ plotted versus carbonate content, Hole U1306A.

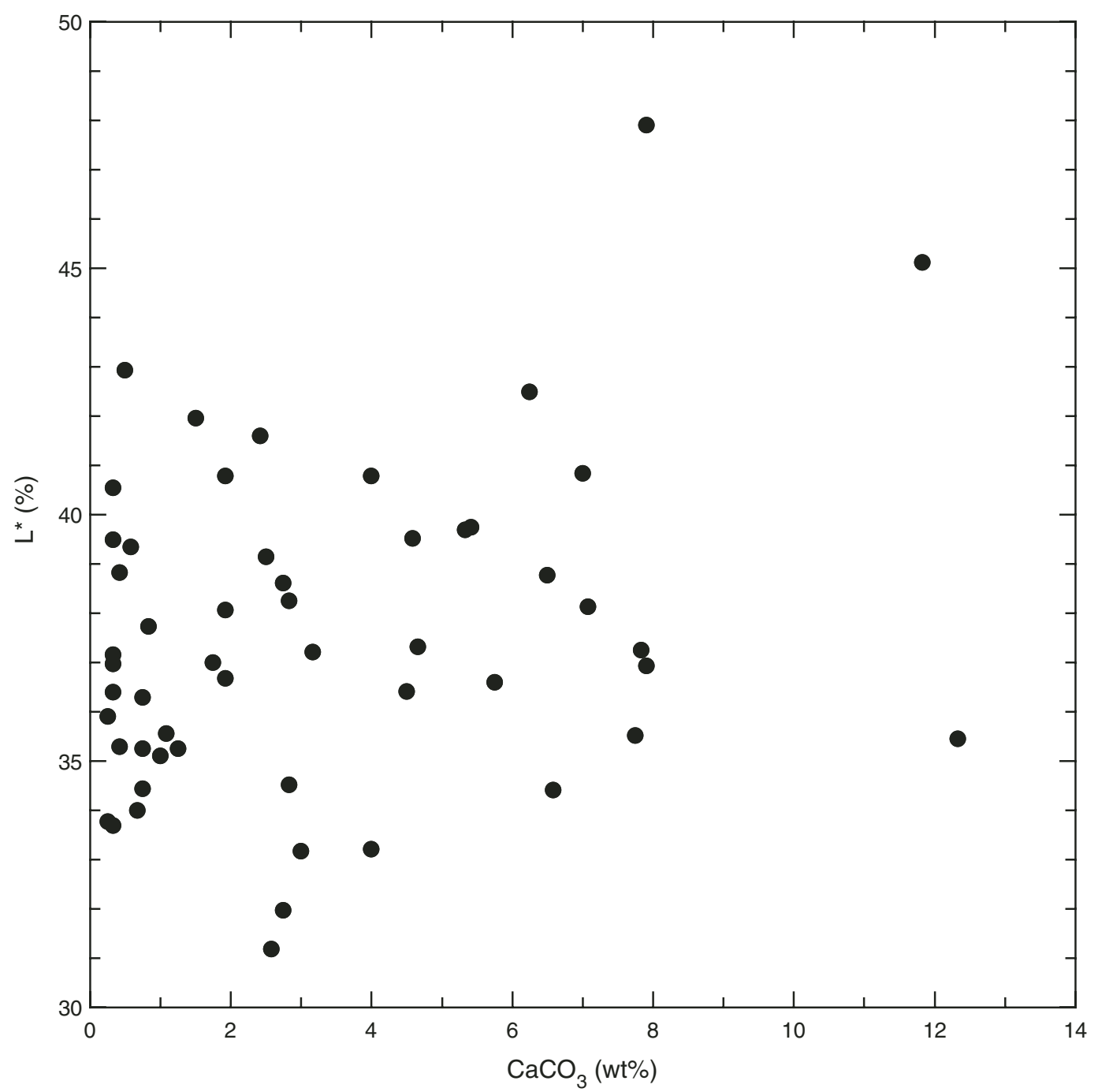


Figure F15. Smoothed color reflectance lightness $\left(\mathrm{L}^{*}\right)$, smoothed magnetic susceptibility (MS), carbonate content, and siliciclastic content from smear slide data (including quartz, feldspar, muscovite, biotite, chlorite, amphibole, epidote, volcanic glass, zeolite, zircon, and "accessory minerals"), Hole U1306A.
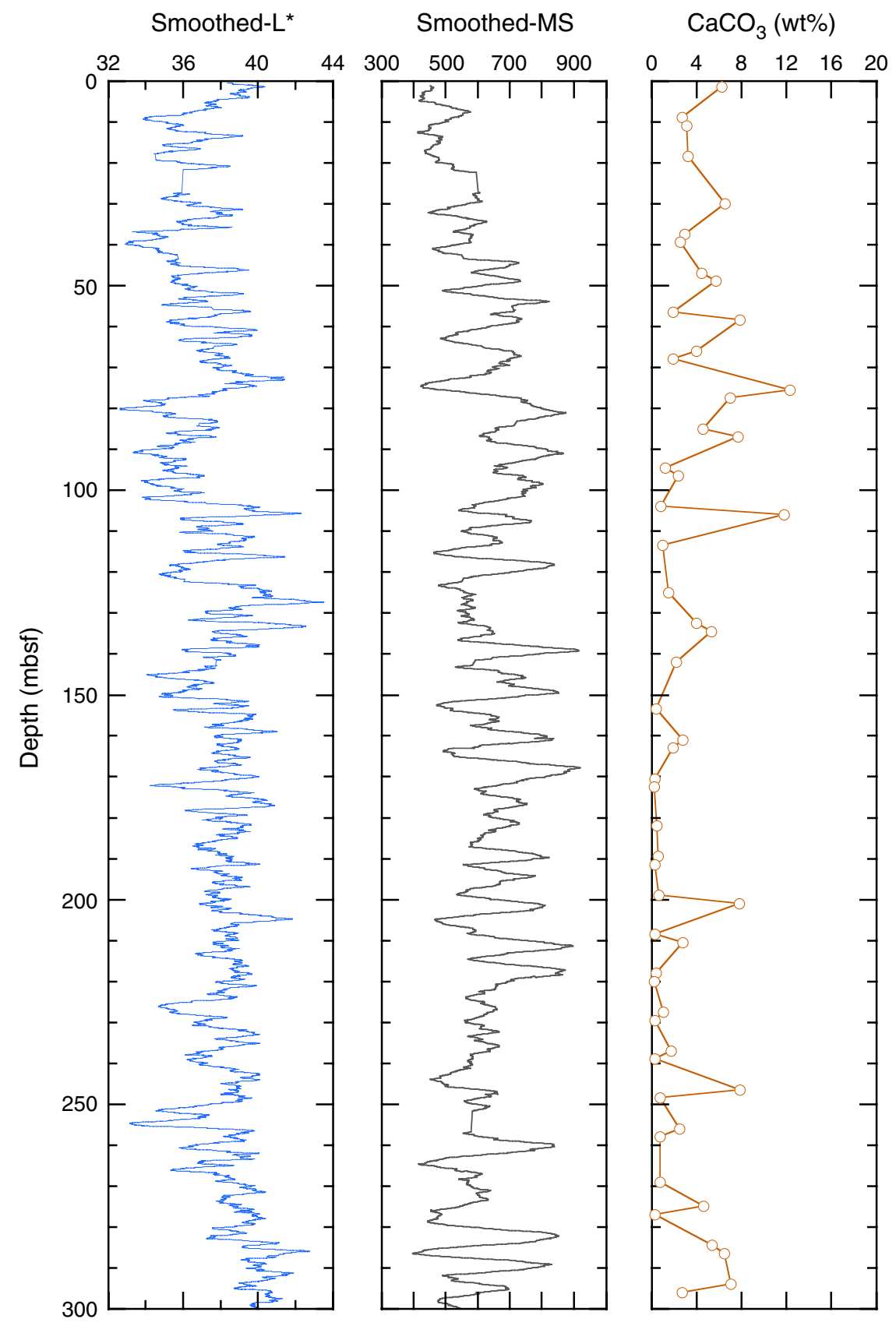

Siliciclastic grains $(\%)$

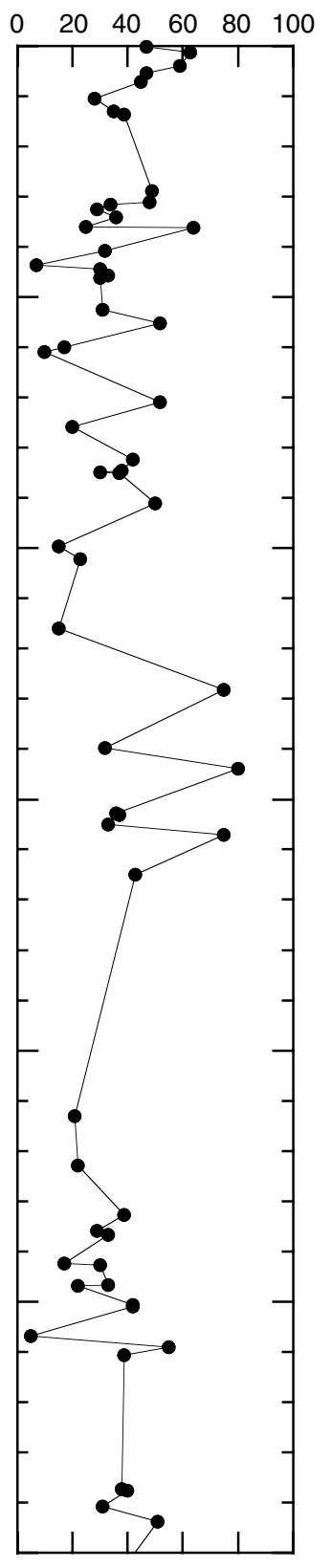


Figure F16. Chronostratigraphic correlation of Holes U1306A-U1306D based on calcareous nannofossils, diatoms, and planktonic foraminifers Relationship to magnetostratigraphy is shown in the left panel. MIS = marine isotope stage, $\mathrm{LO}=$ last occurrence, $\mathrm{FO}=$ first occurrence .

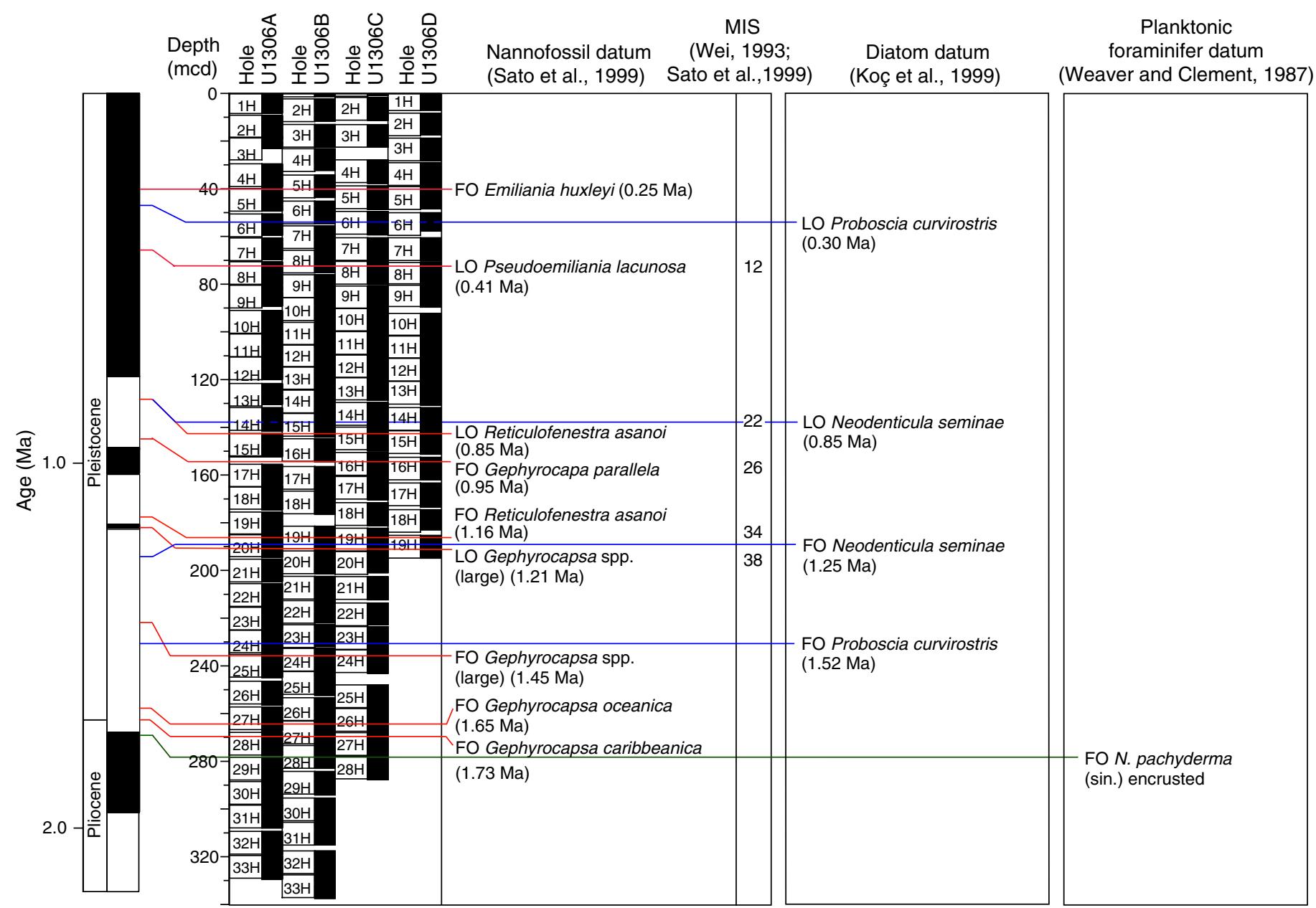


Figure F17. Site U1306 downcore relative abundance of calcareous nannofossils, planktonic foraminifers, diatoms, radiolarians, and palynomorphs. $\times=$ reworked pollen.

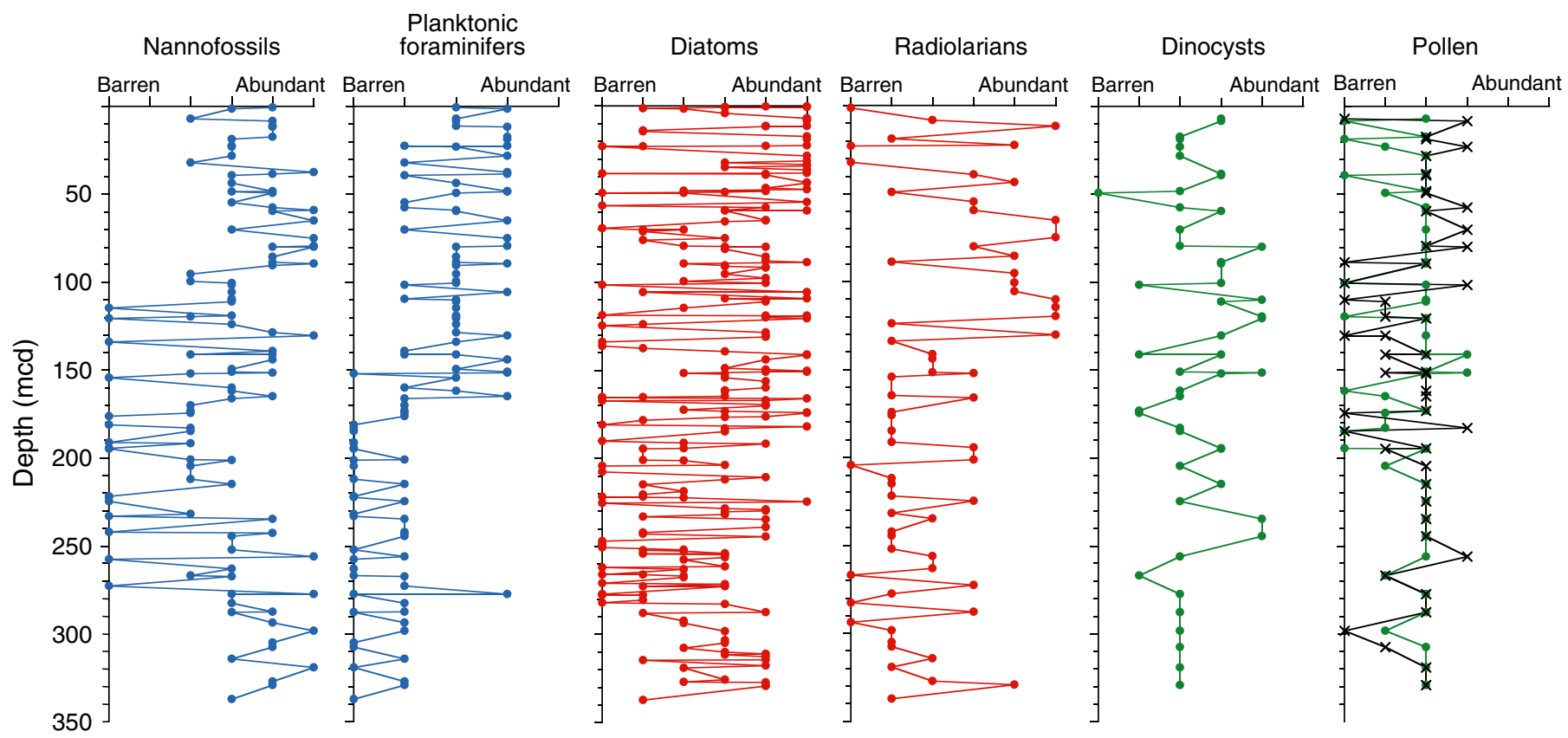


Figure F18. Site U1306 downcore preservation of calcareous nannofossils, planktonic foraminifers, diatoms, and radiolarians.

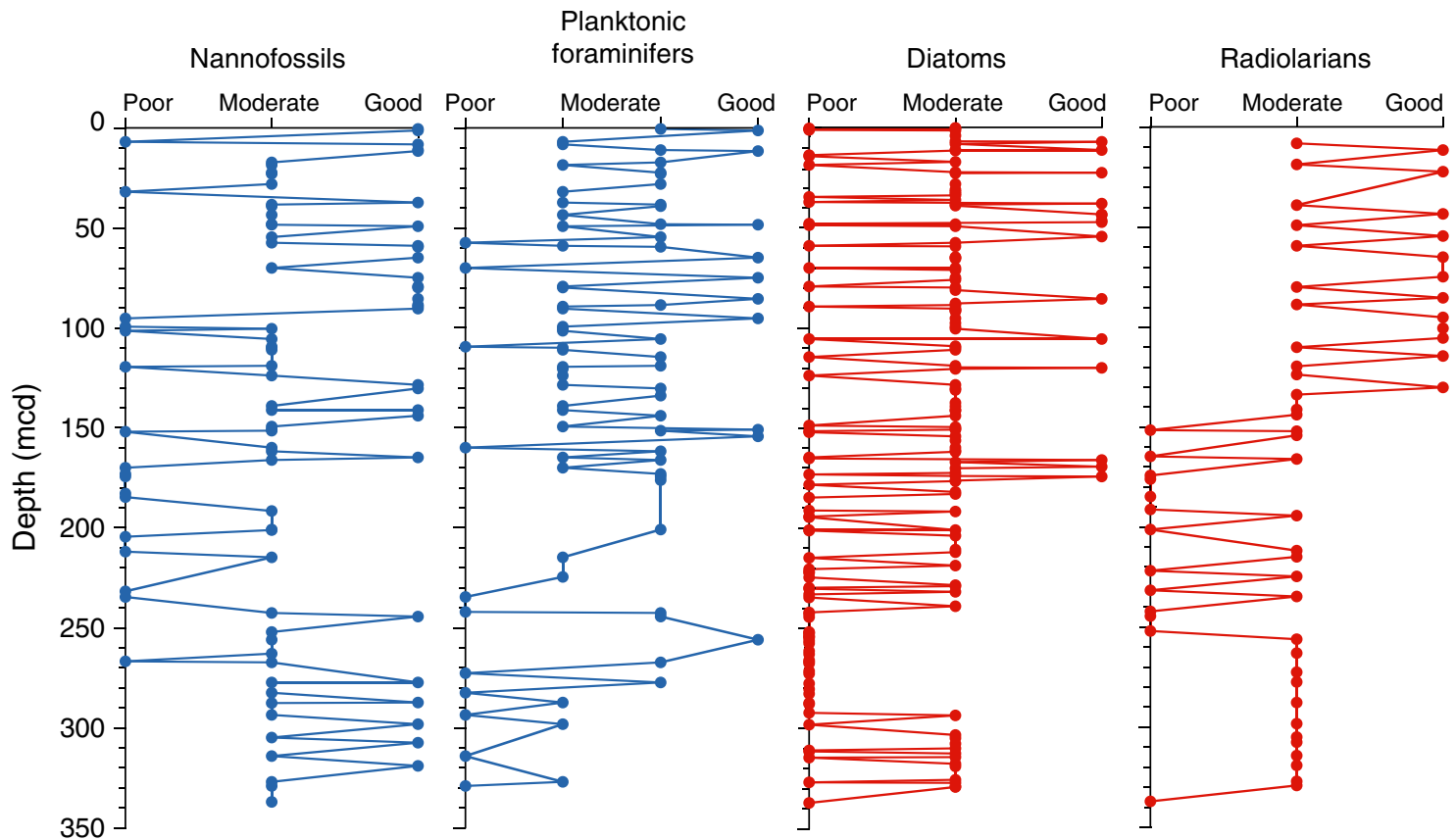


Figure F19. Site U1306 magnetization intensity before and after AF demagnetization versus depth. Green, orange, and red curves indicate intensity before demagnetization and after demagnetization at AF peak fields of 10 and $20 \mathrm{mT}$, respectively. Core recovery is shown in the left panel.

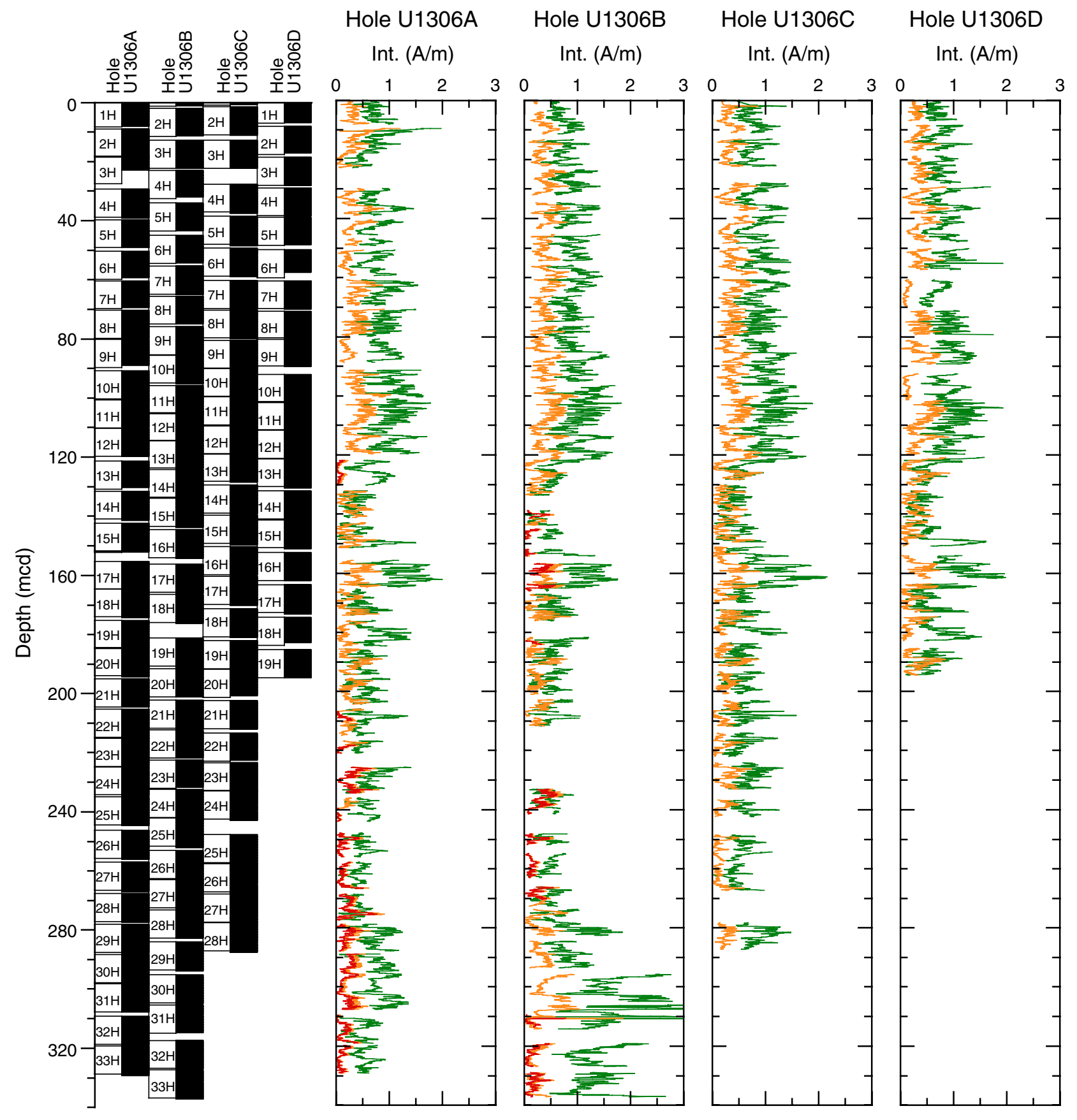


Figure F20. Site U1306 inclination of remanent magnetization after AF demagnetization versus depth. Black and blue curves indicate results obtained after demagnetization at AF peak fields of 10 and $20 \mathrm{mT}$, respectively. Core recovery is shown in the left panel.

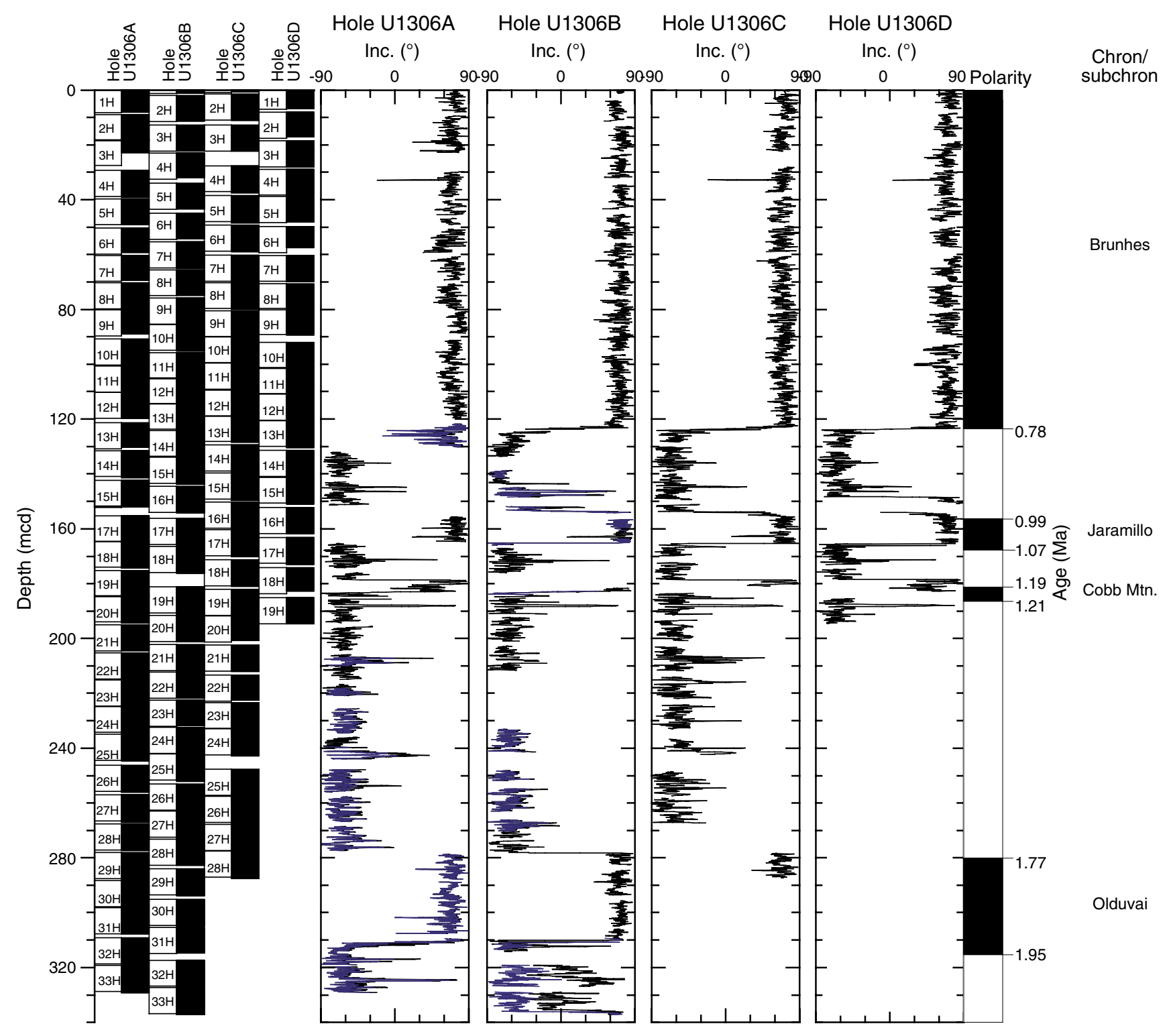


Figure F21. Site U1306 declination of remanent magnetization after AF demagnetization versus depth. Black and blue symbols indicate results obtained after demagnetization at AF peak fields of 10 and $20 \mathrm{mT}$. Core recovery is shown in the left panel.

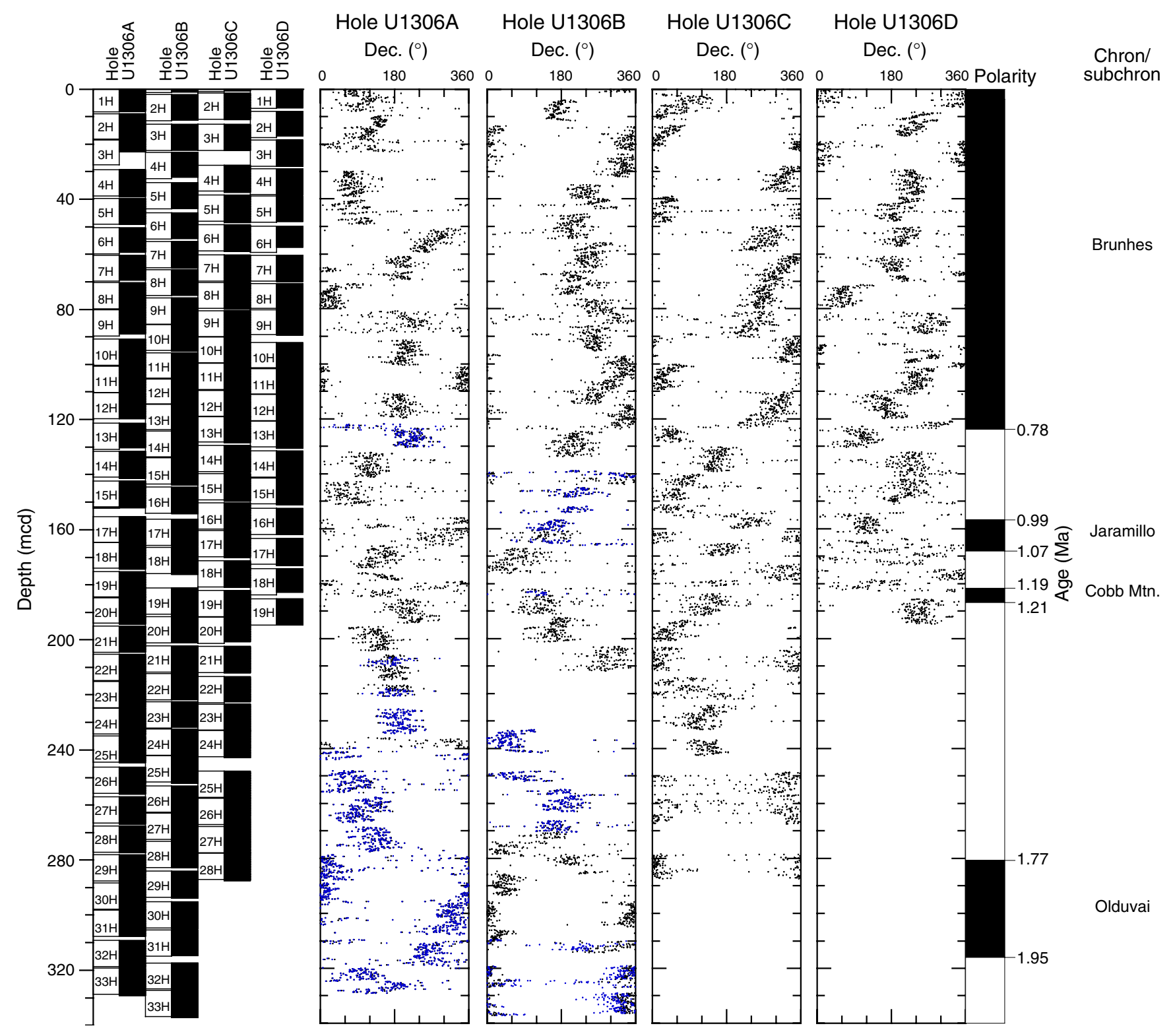


Figure F22. Lower panel: Magnetic susceptibility versus depth for each hole drilled at Site U1306. Numbers below curves indicate core number for each record. Upper panel: Composite magnetic susceptibility record indicating which hole was used to form the splice. A. 0-50 mcd. (Continued on next six pages.)

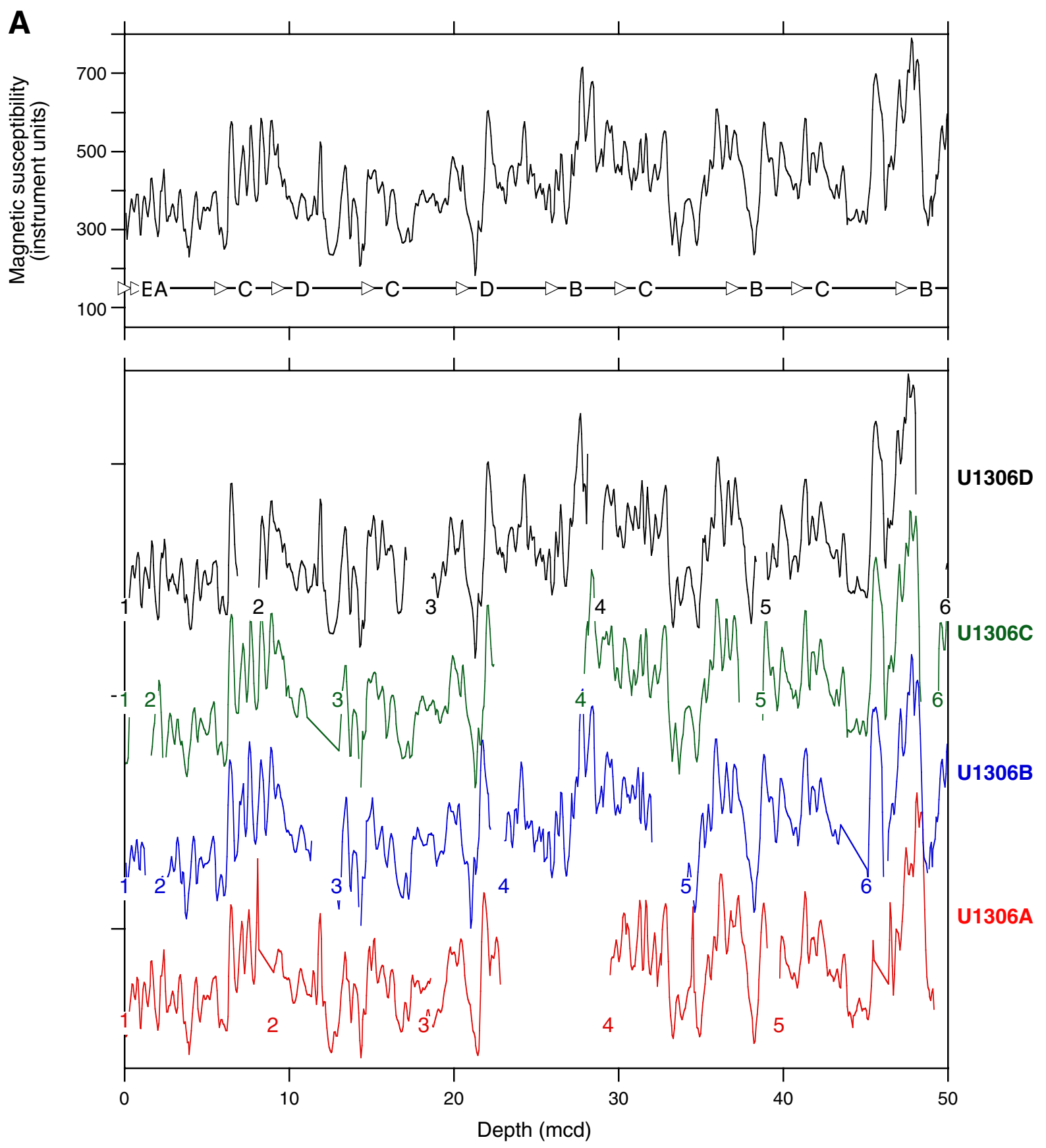


Figure F22 (continued). B. 50-100 mcd.

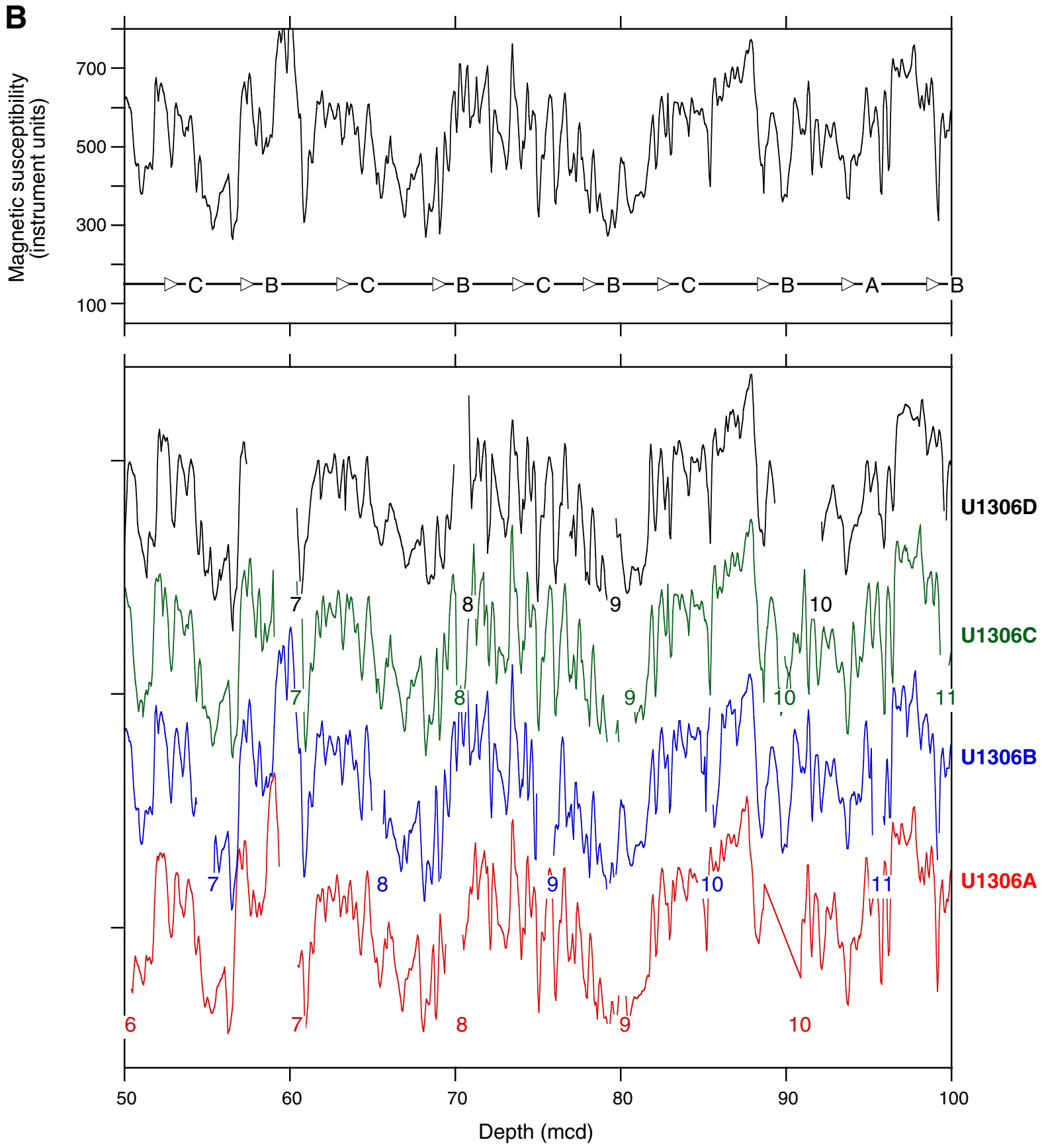


Figure F22 (continued). C. 100-150 mcd.

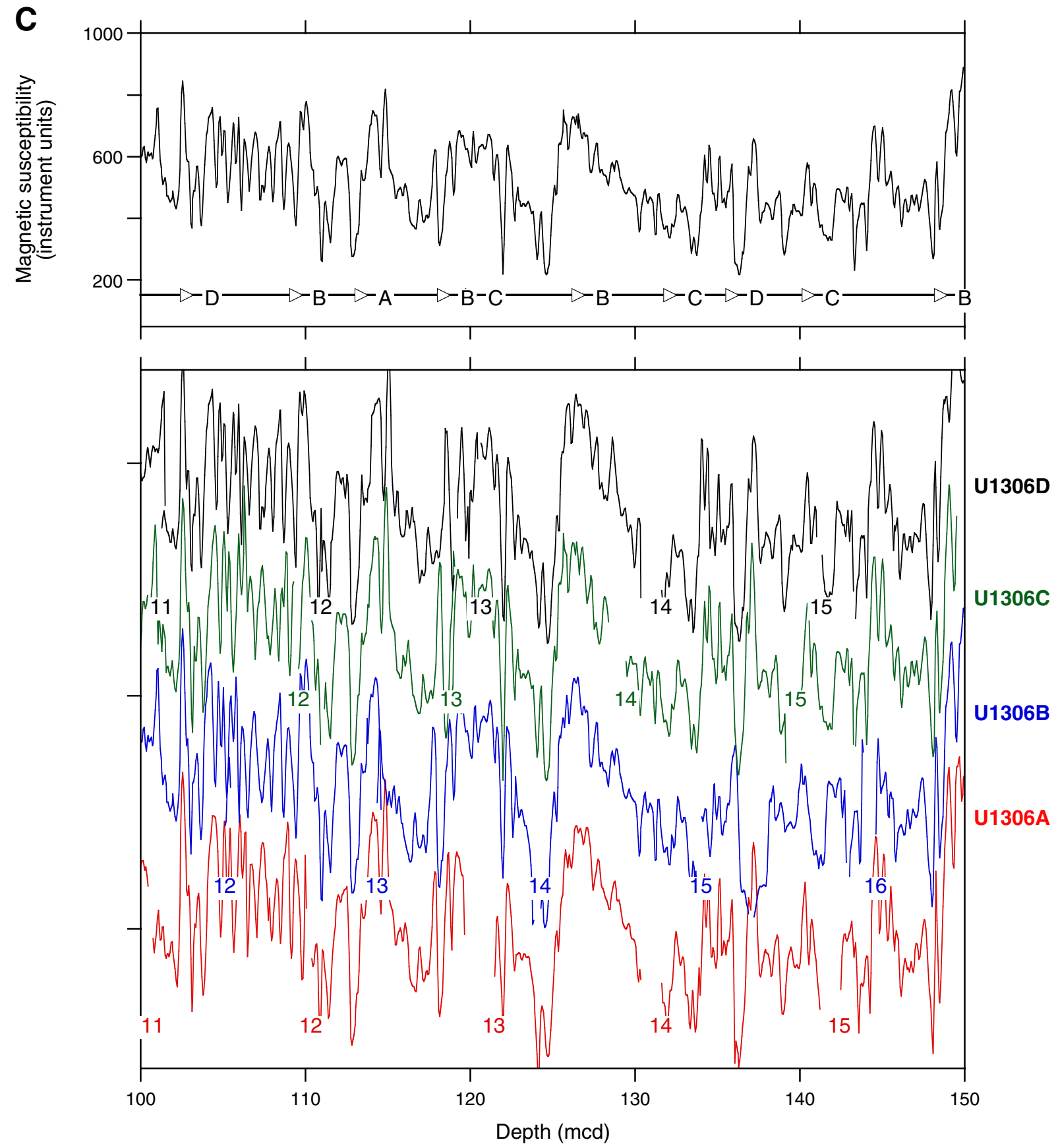


Figure F22 (continued). D. 150-200 mcd.

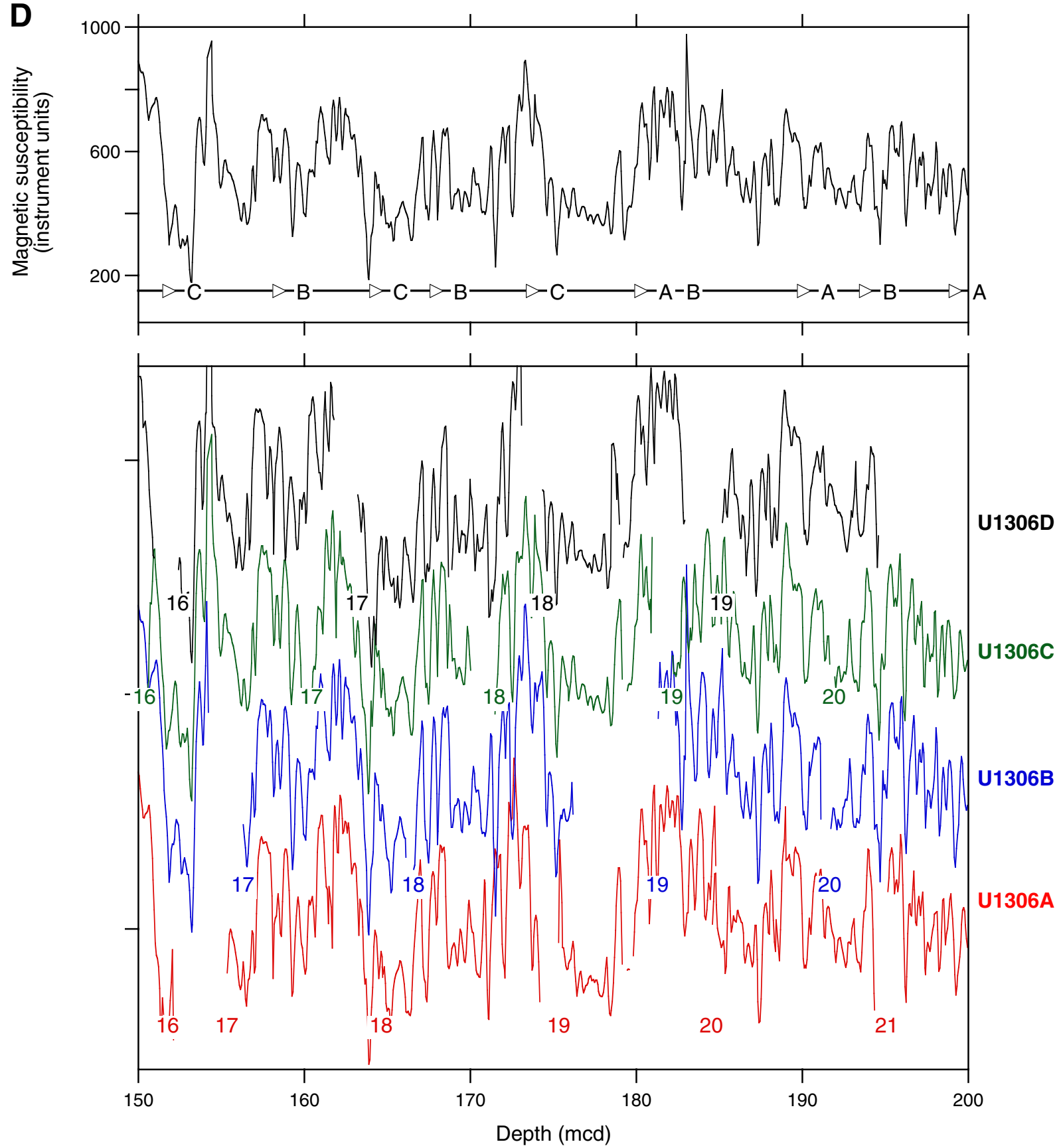


Figure F22 (continued). E. 200-250 mcd.
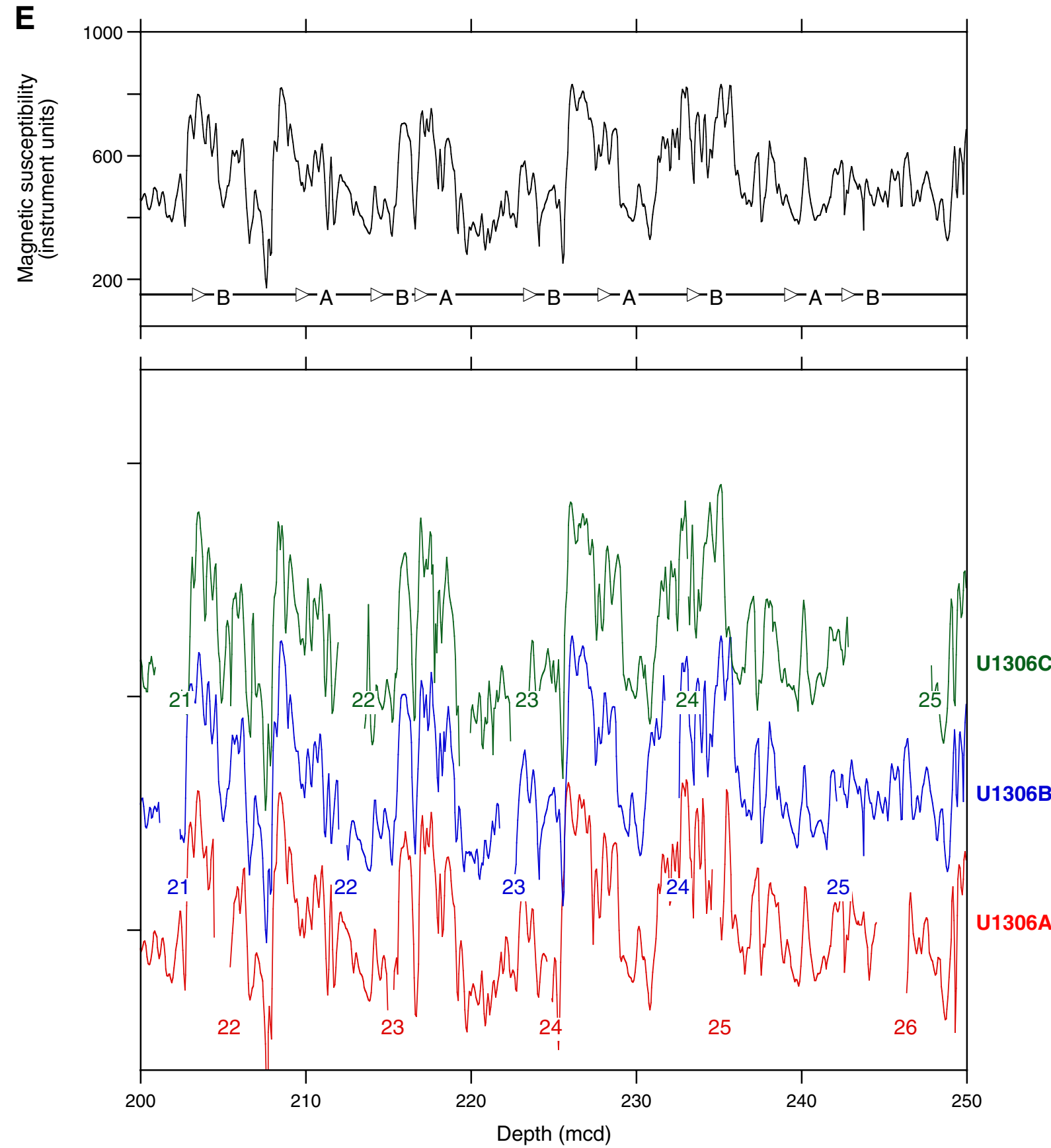
Figure F22 (continued). F. 250-300 mcd.
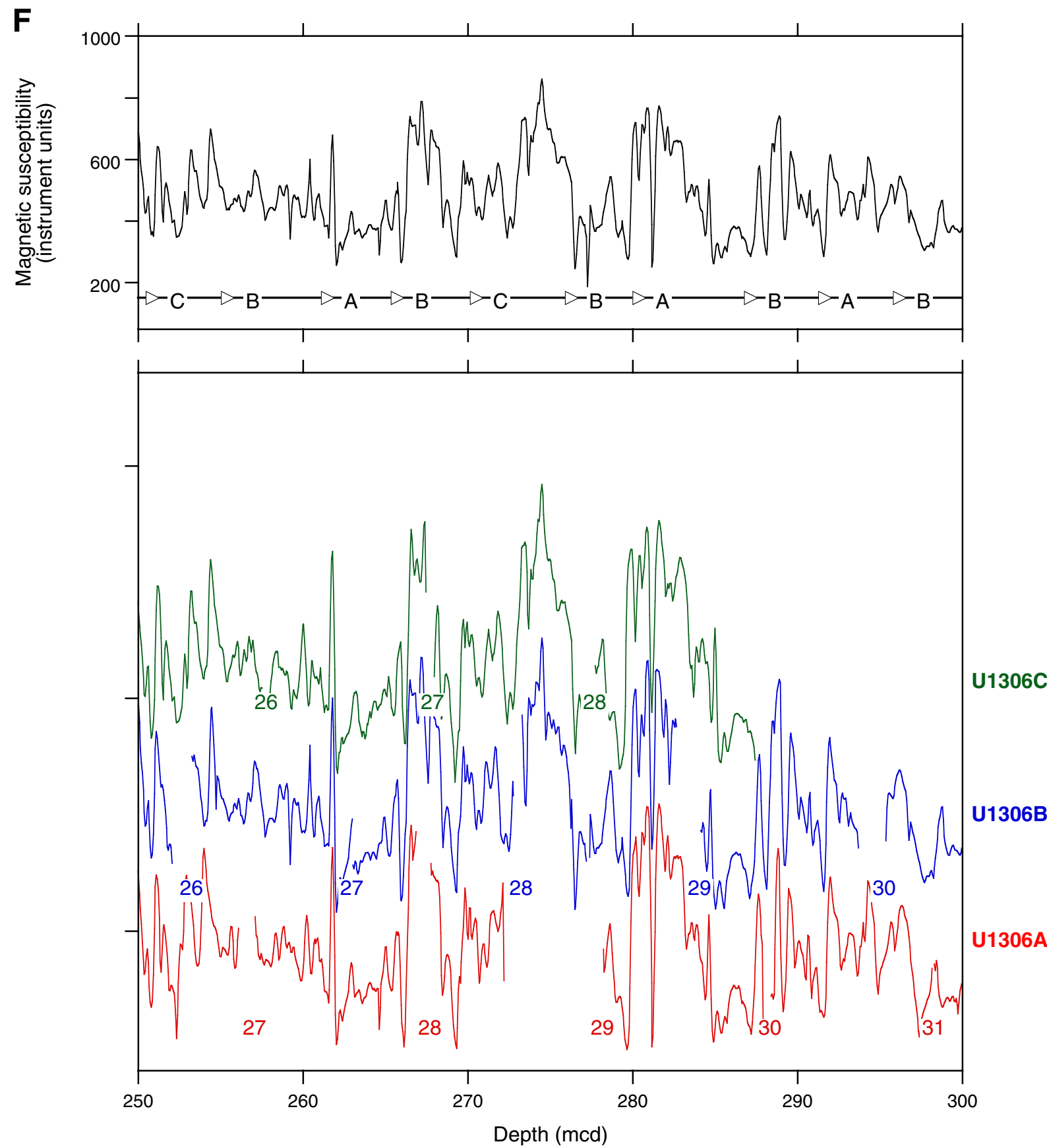
Figure F22 (continued). G. 300-350 mcd.
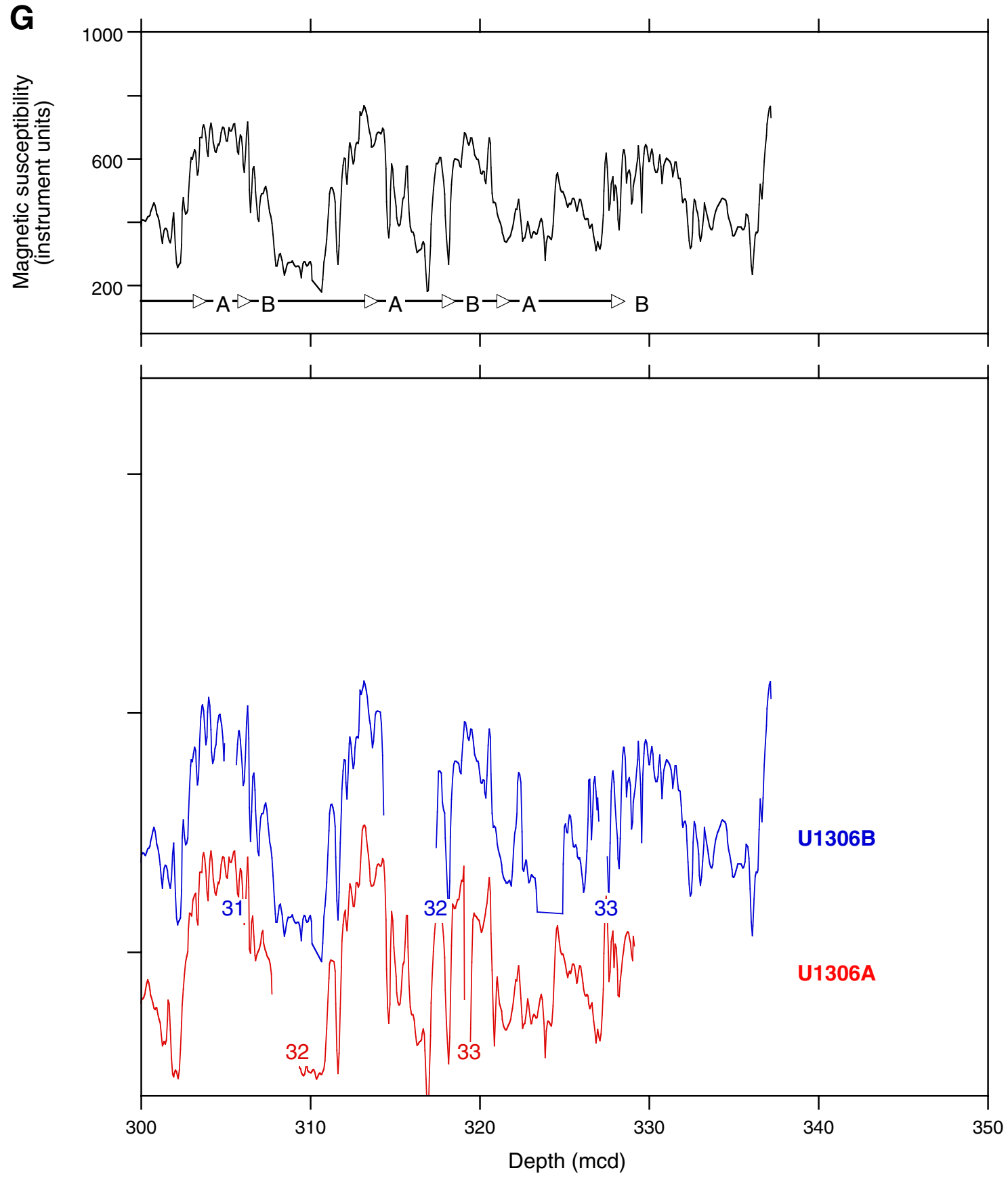
Figure F23. Meters composite depth versus meters below seafloor for tops of cores at Site U1306. The growth factor $(\mathrm{GF}=1.08)$ is the slope of the regression line. On average, the mcd of the spliced section is $8 \%$ greater than meters below seafloor.

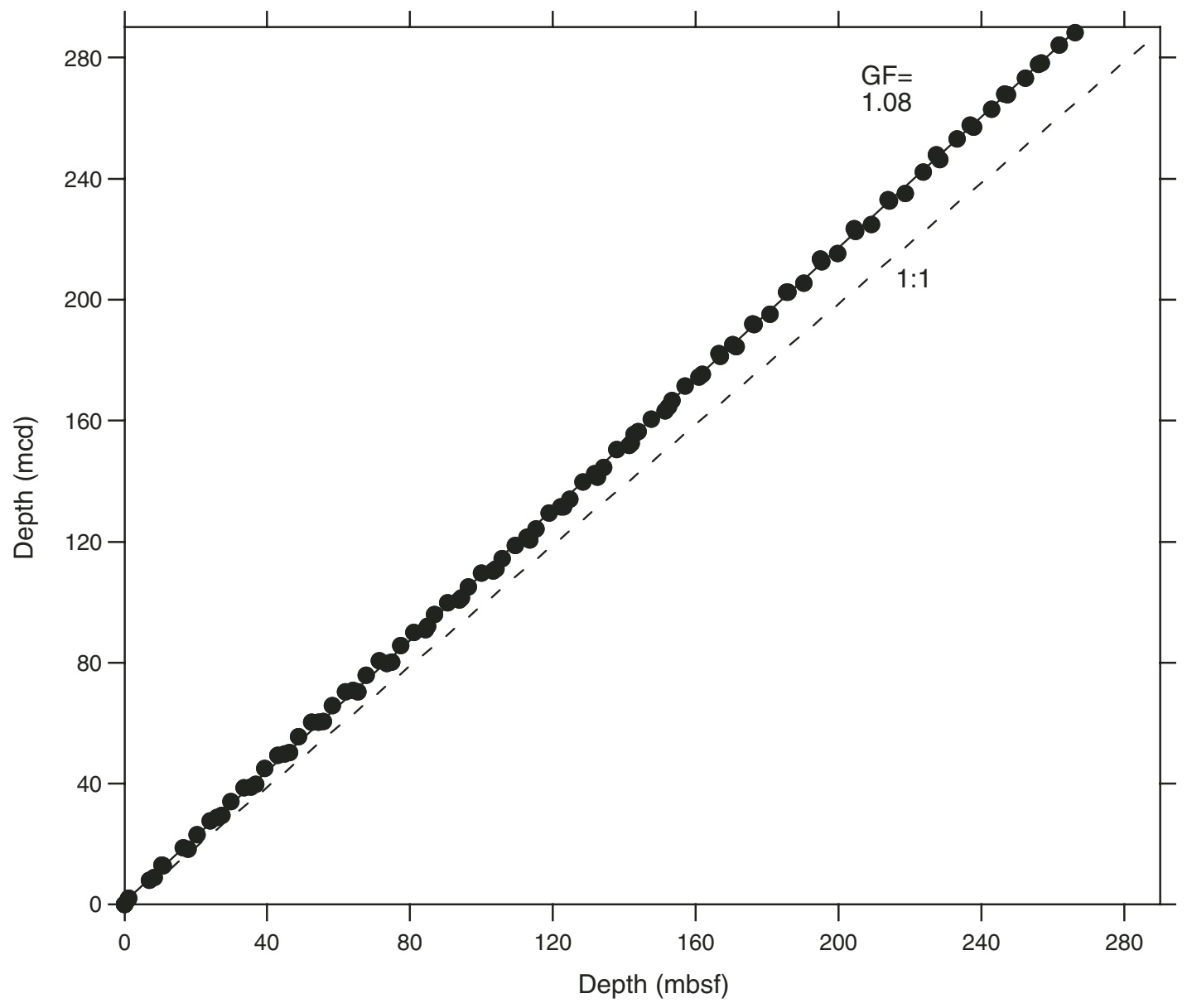


Figure F24. A. Age versus depth for biostratigraphic and paleomagnetic datums for Site U1306. A mean sedimentation rate of $15.6 \mathrm{~cm} / \mathrm{k}$.y. was calculated by linear regression. B. Same datums shown in A with the interval sedimentation rates derived from the paleomagnetic datums only.
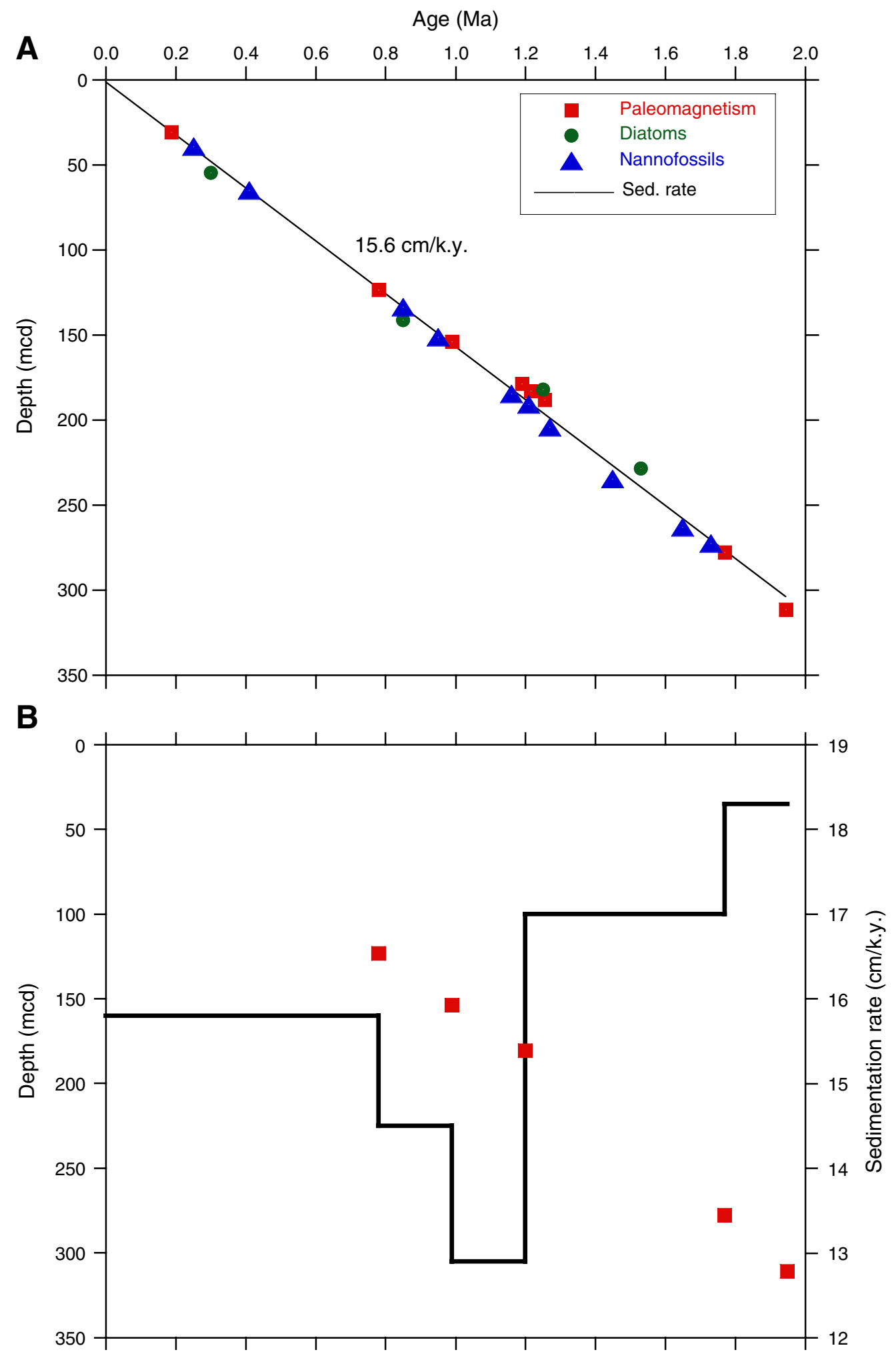
Figure F25. Headspace methane and ethane concentrations for Hole U1306A.

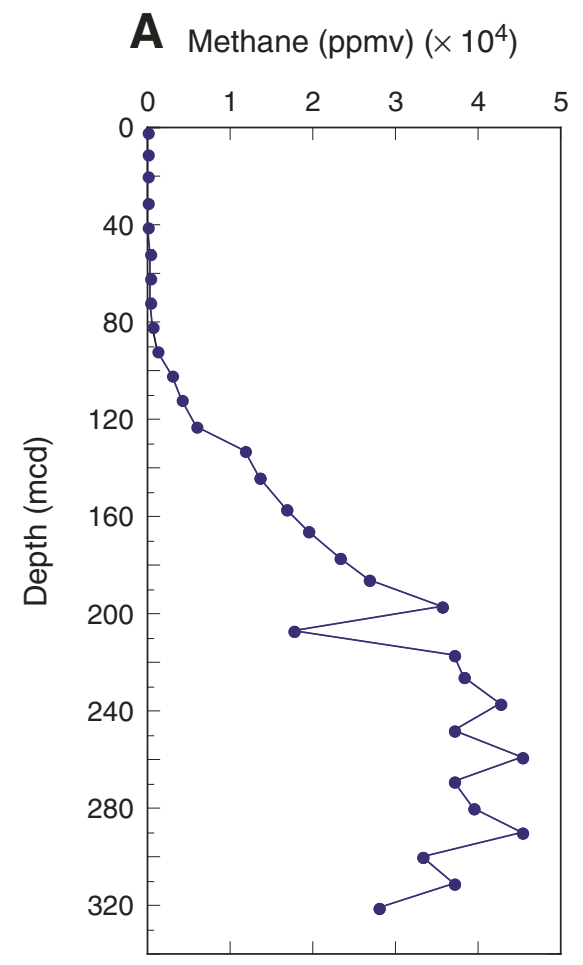

B Ethane (ppmv)

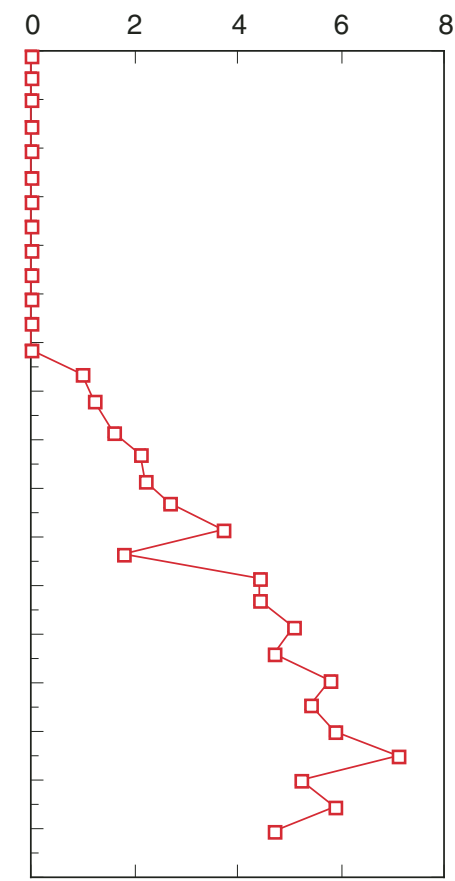


Figure F26. Site U1306 carbonate contents and elemental compositions. A. Calcium carbonate. B. Total organic carbon (TOC). C. Elemental nitrogen. D. Organic C/N ratio.

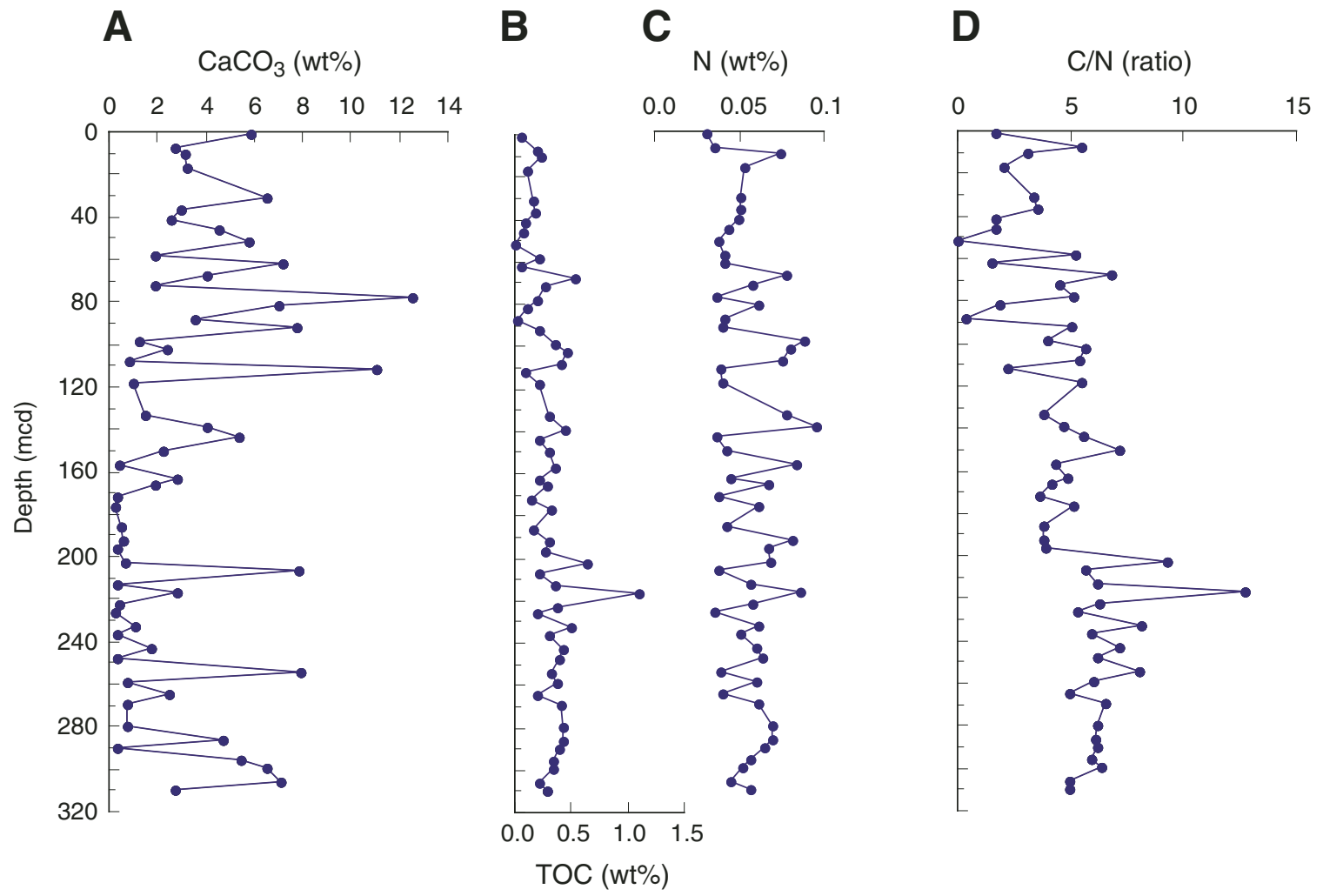


Figure F27. Profiles of chemical constituents in interstitial waters from Hole U1306A. A. Chloride. B. Sodium. C. pH. D. Boron. E. Alkalinity. F. Sulfate. G. Ammonium. H. Dissolved silica. (Continued on next page.)

A

B
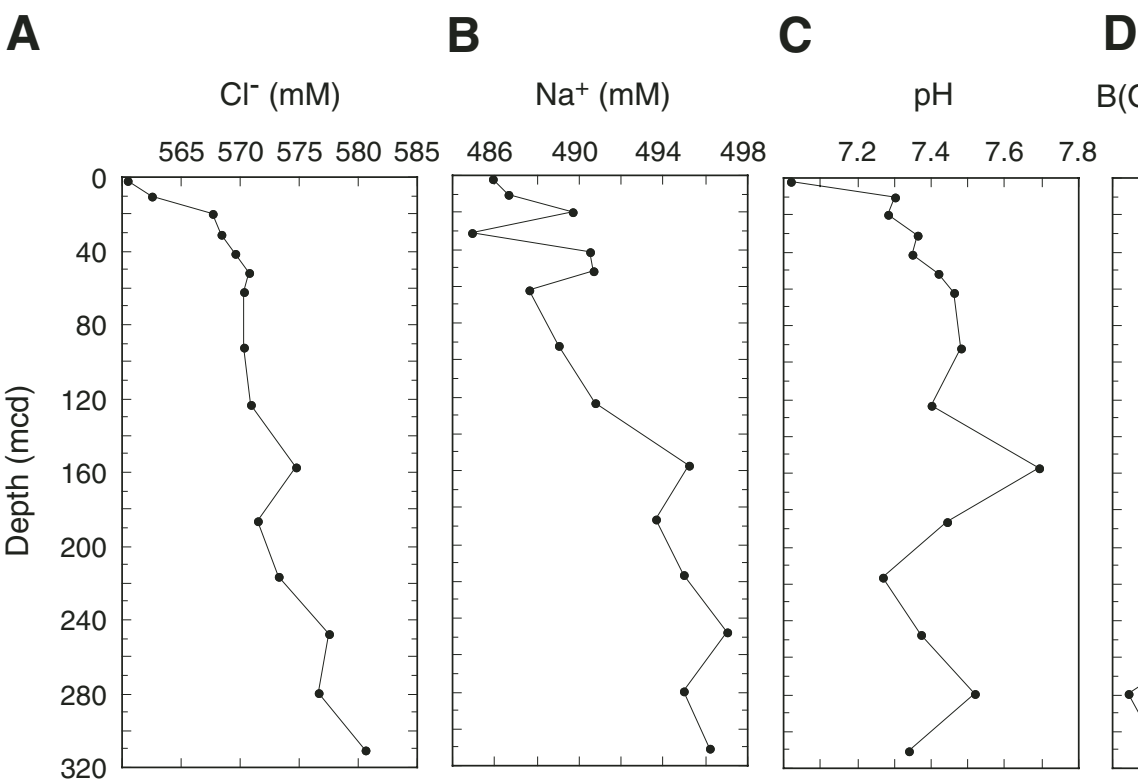

$\mathrm{Na}^{+}(\mathrm{mM})$

$\mathrm{pH}$

$\mathrm{B}(\mathrm{OH})_{3}+\mathrm{B}(\mathrm{OH})_{4}^{-}(\mu \mathrm{M})$
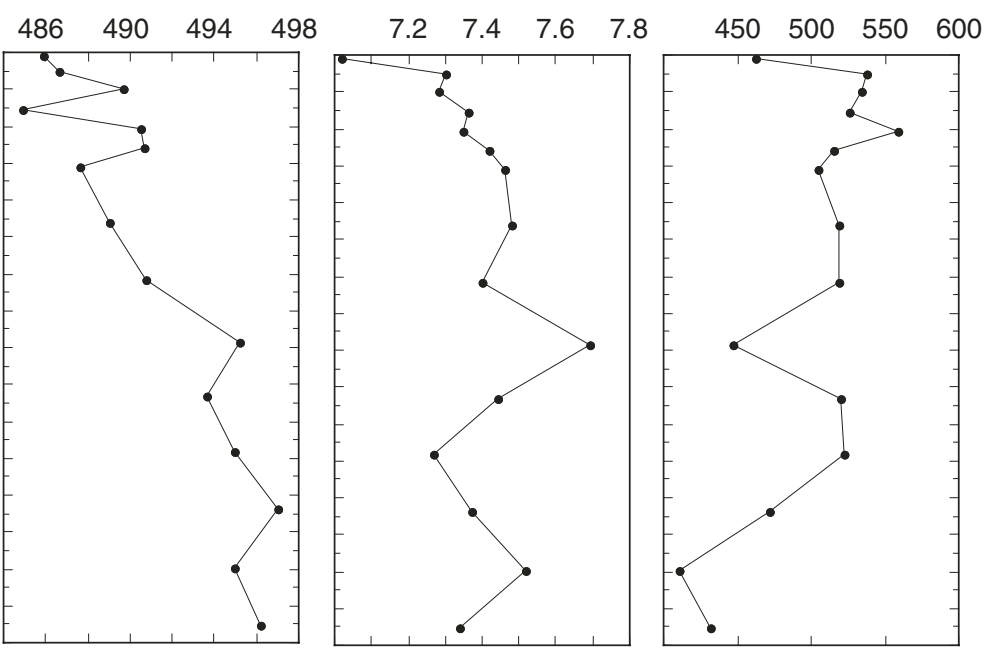

E

$\mathbf{F}$

G

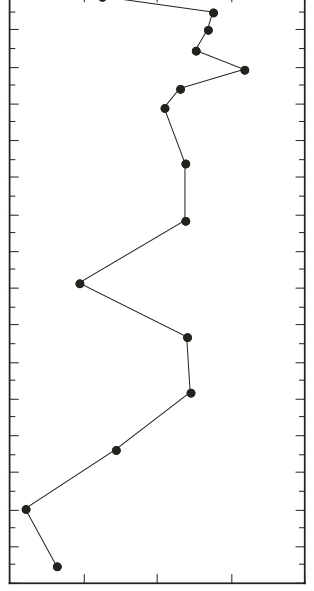

Alkalinity (mM)

$\mathrm{SO}_{4}^{2-}(\mathrm{mM})$

$\mathrm{NH}_{4}{ }^{+}(\mathrm{mM})$

H
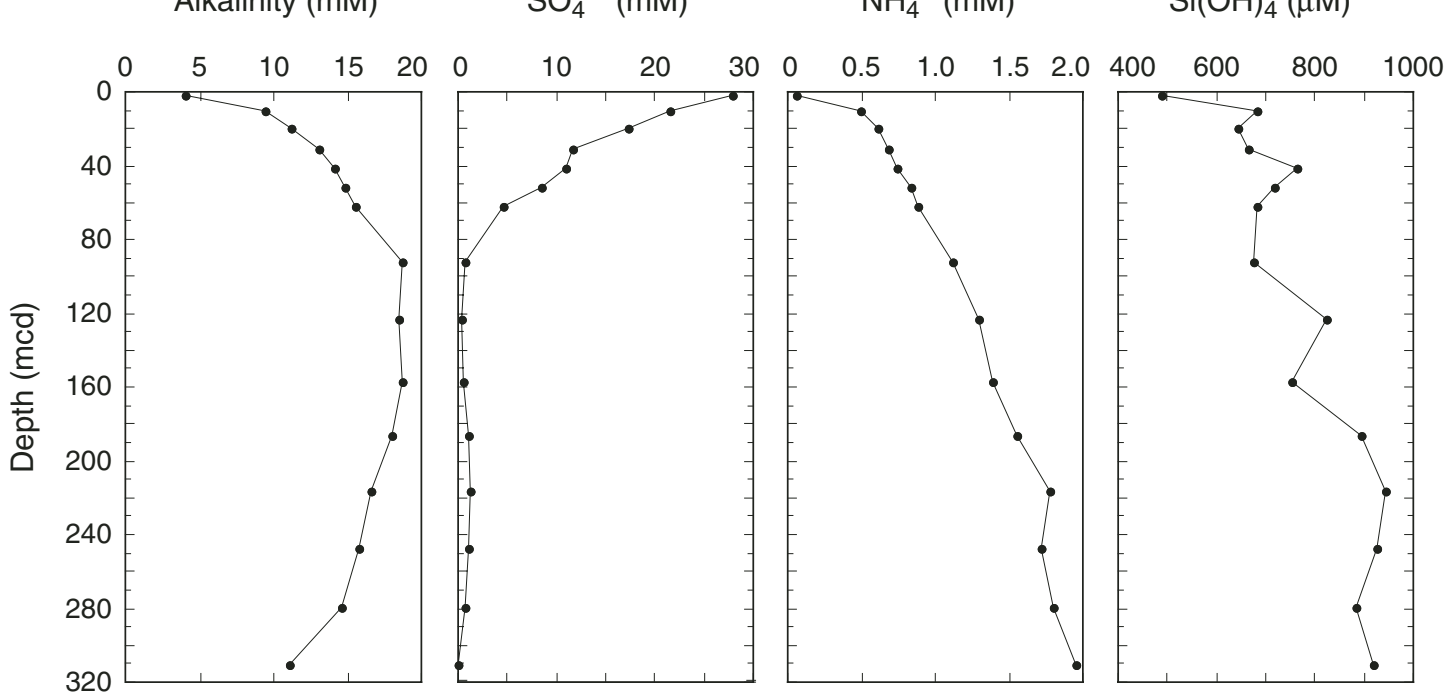
Figure F27 (continued). I. Calcium. J. Strontium and Sr/Ca ratio. K. Lithium. L. Barium and sulfate. M. Magnesium. N. Potassium. O. Manganese. P. Iron and $\mathrm{pH}$.
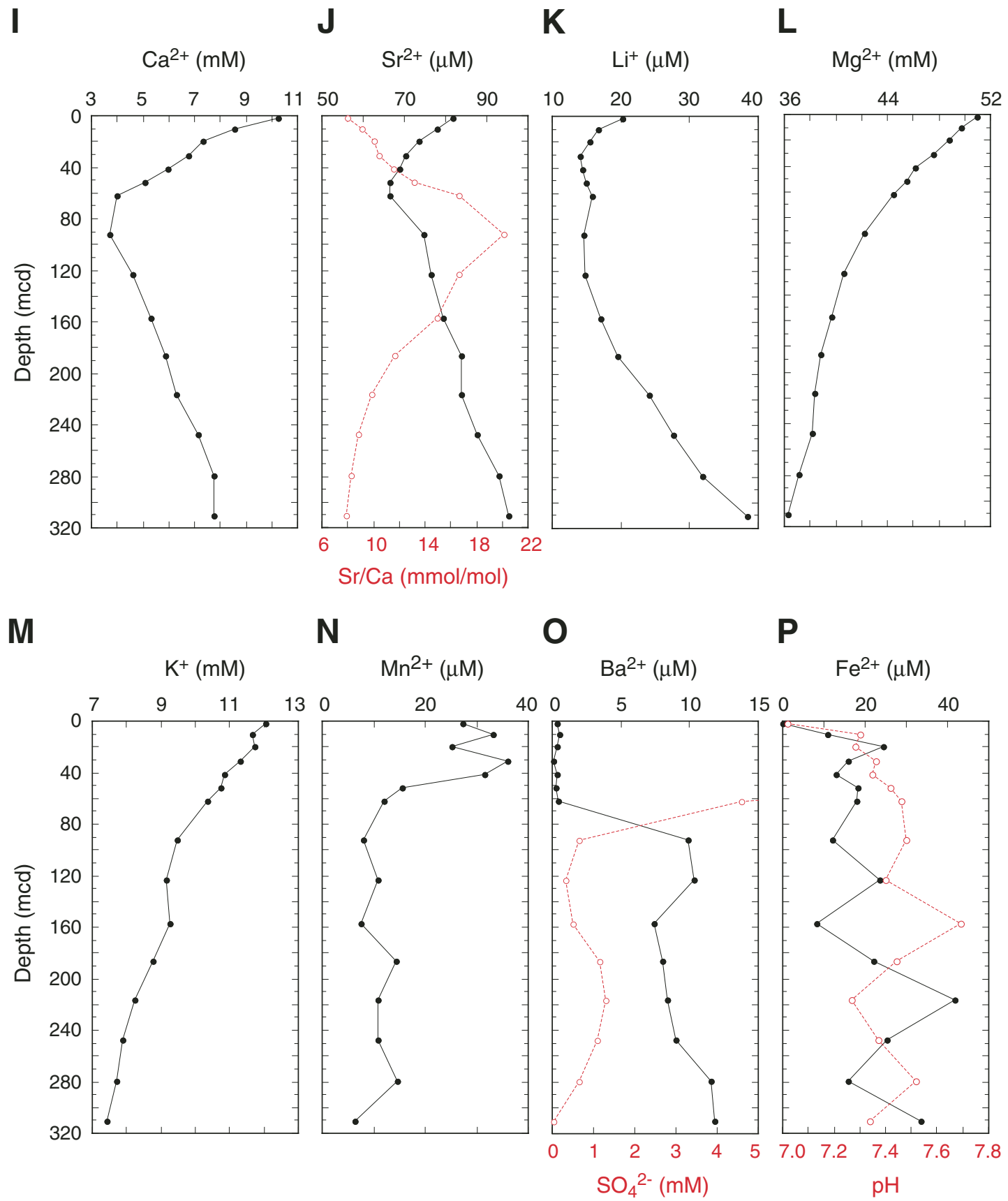
Figure F28. Site U1306 magnetic susceptibility (MS) records. Core recovery columns are represented on the left side. Black = multisensor track (MST) record, red = magnetic susceptibility core logger (MSCL) record.

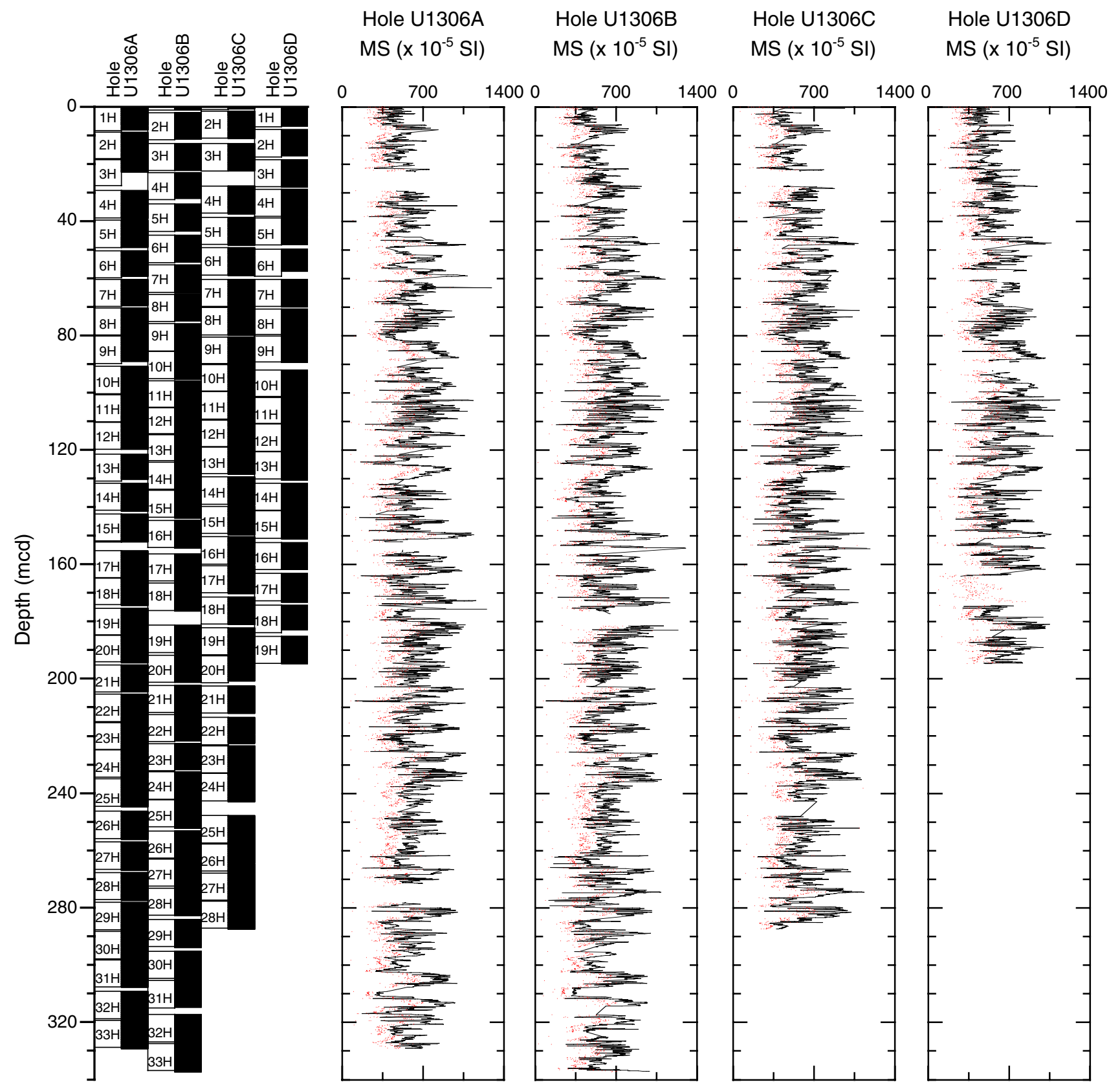


Figure F29. Combined gamma ray attenuation (GRA) density measurements from the multisensor track and bulk density from discrete measurements (red circles), Site U1306.

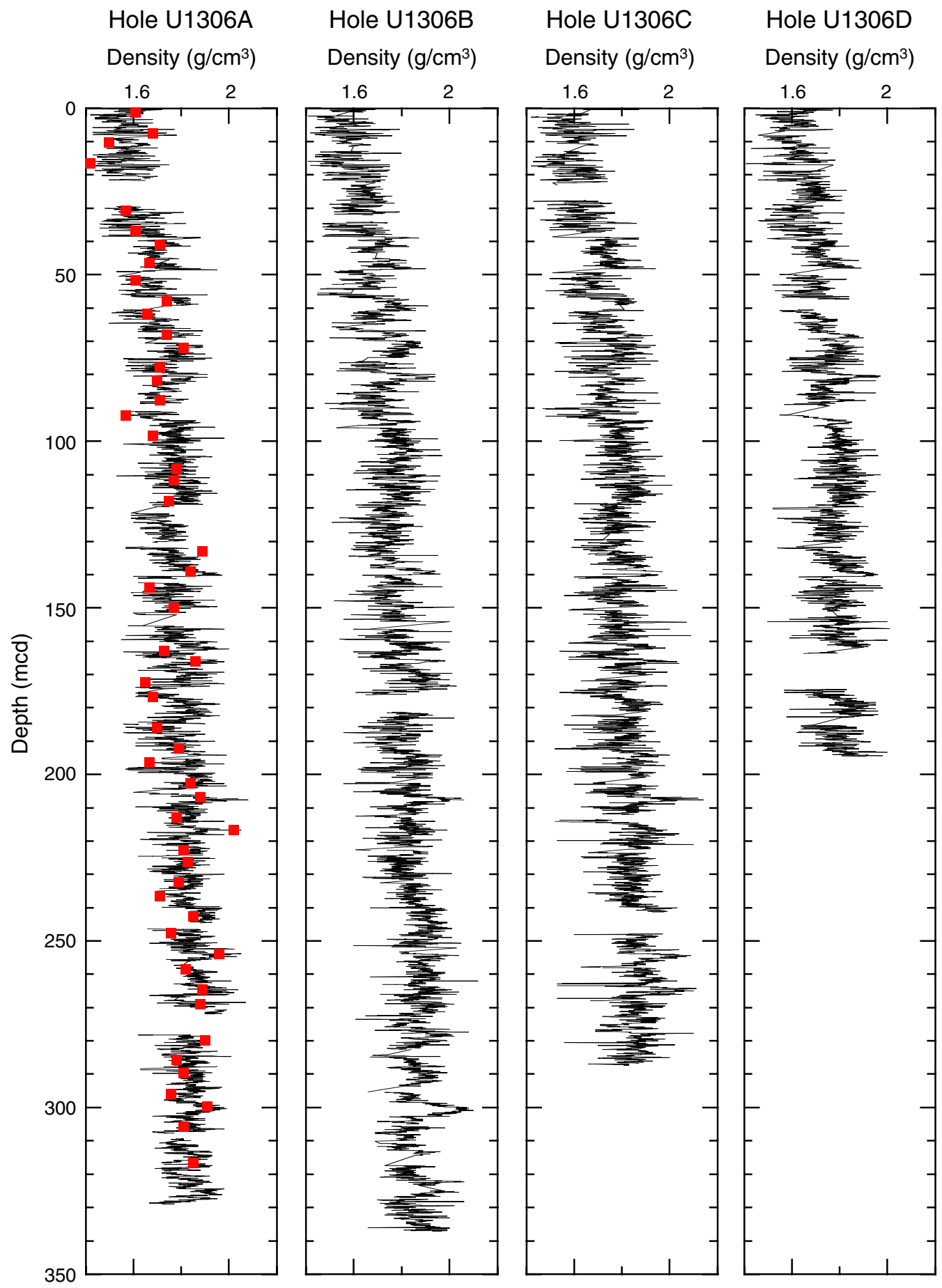


Figure F30. Natural gamma ray (NGR) counts from the multisensor track, Site U1306.

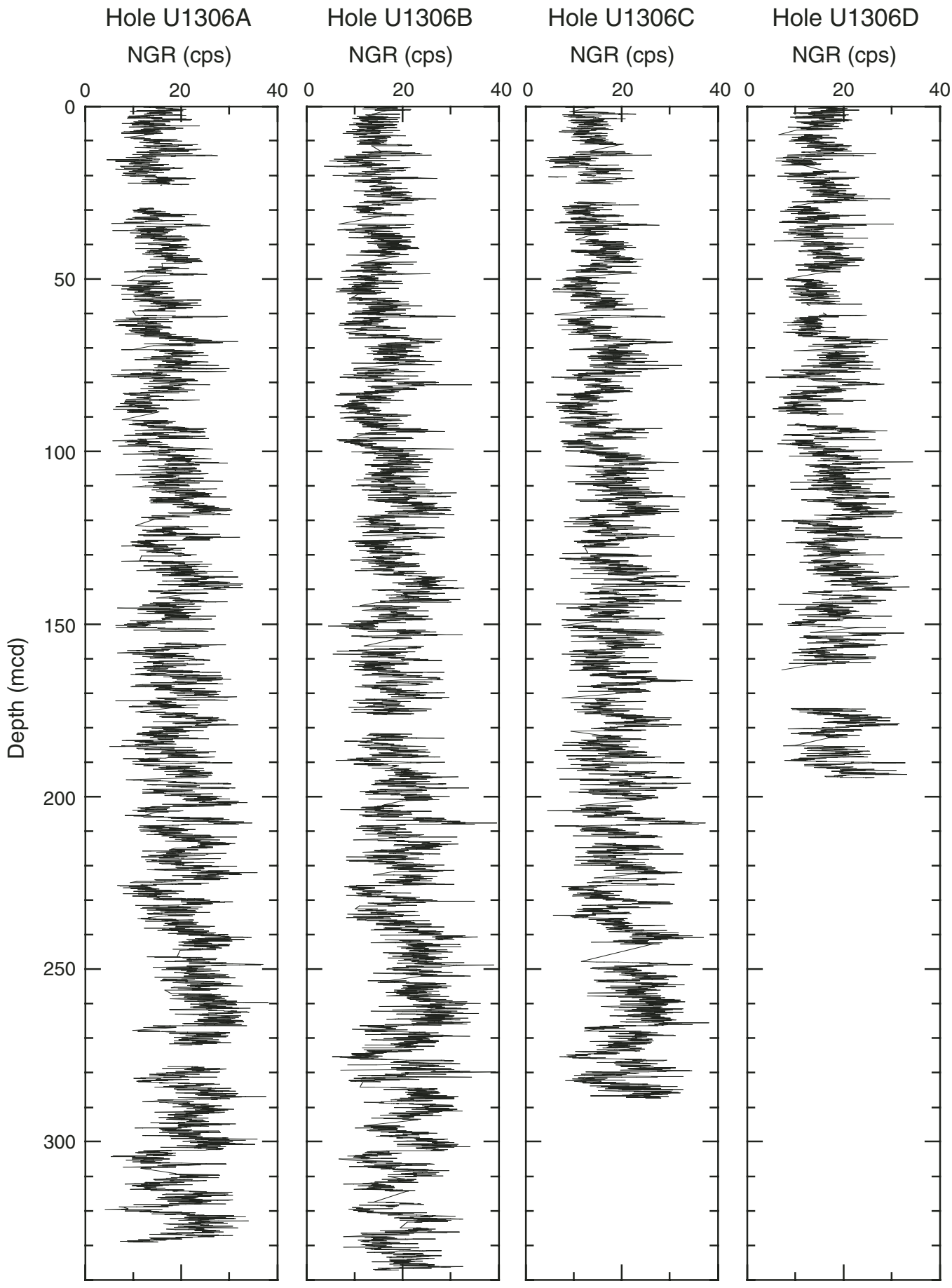


Figure F31. Downcore $P$-wave velocity records, Site U1306.

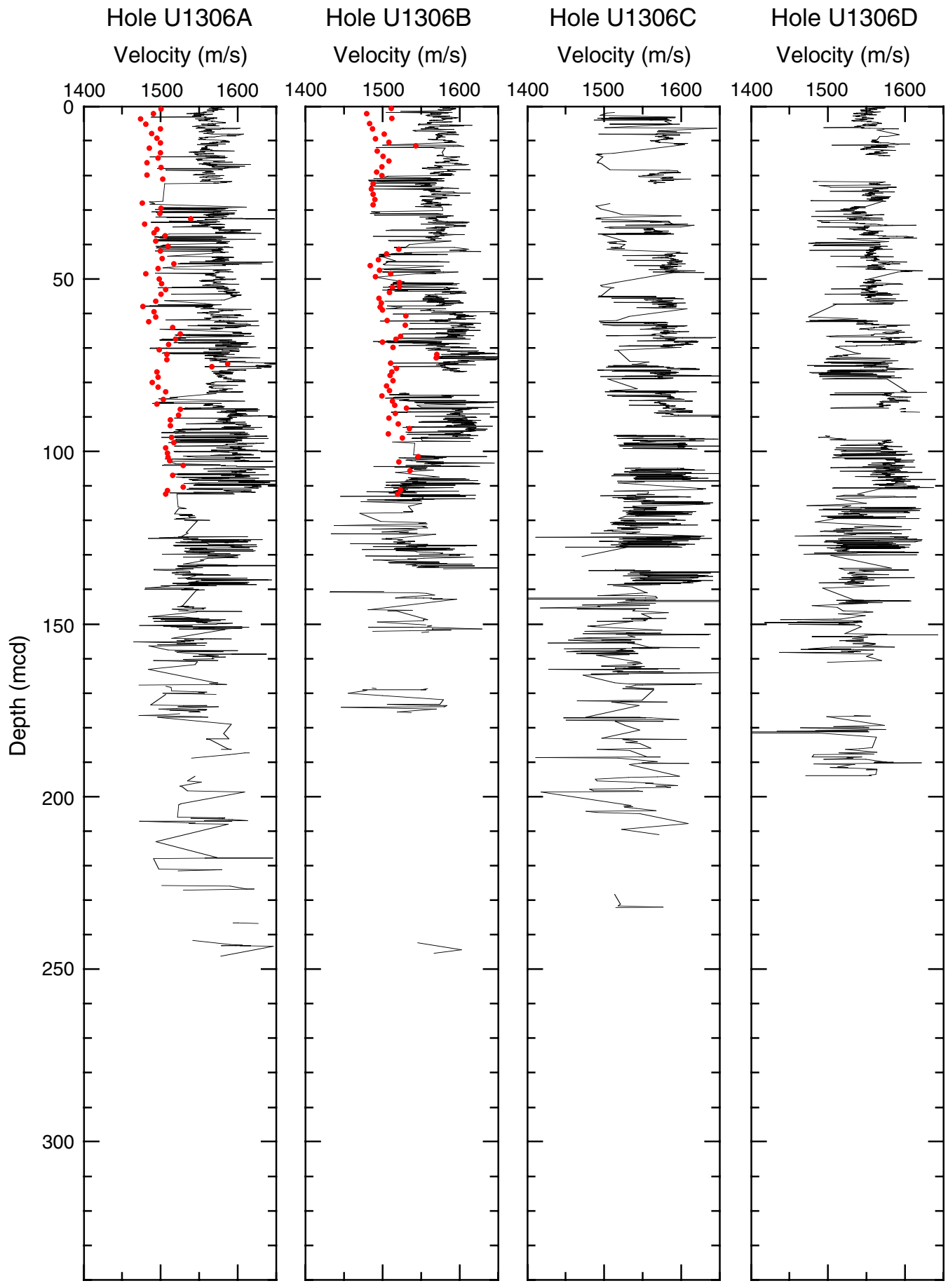


Figure F32. Downcore gamma ray attenuation-derived porosity calculations and discrete porosity measurements (red circles), Site U1306.

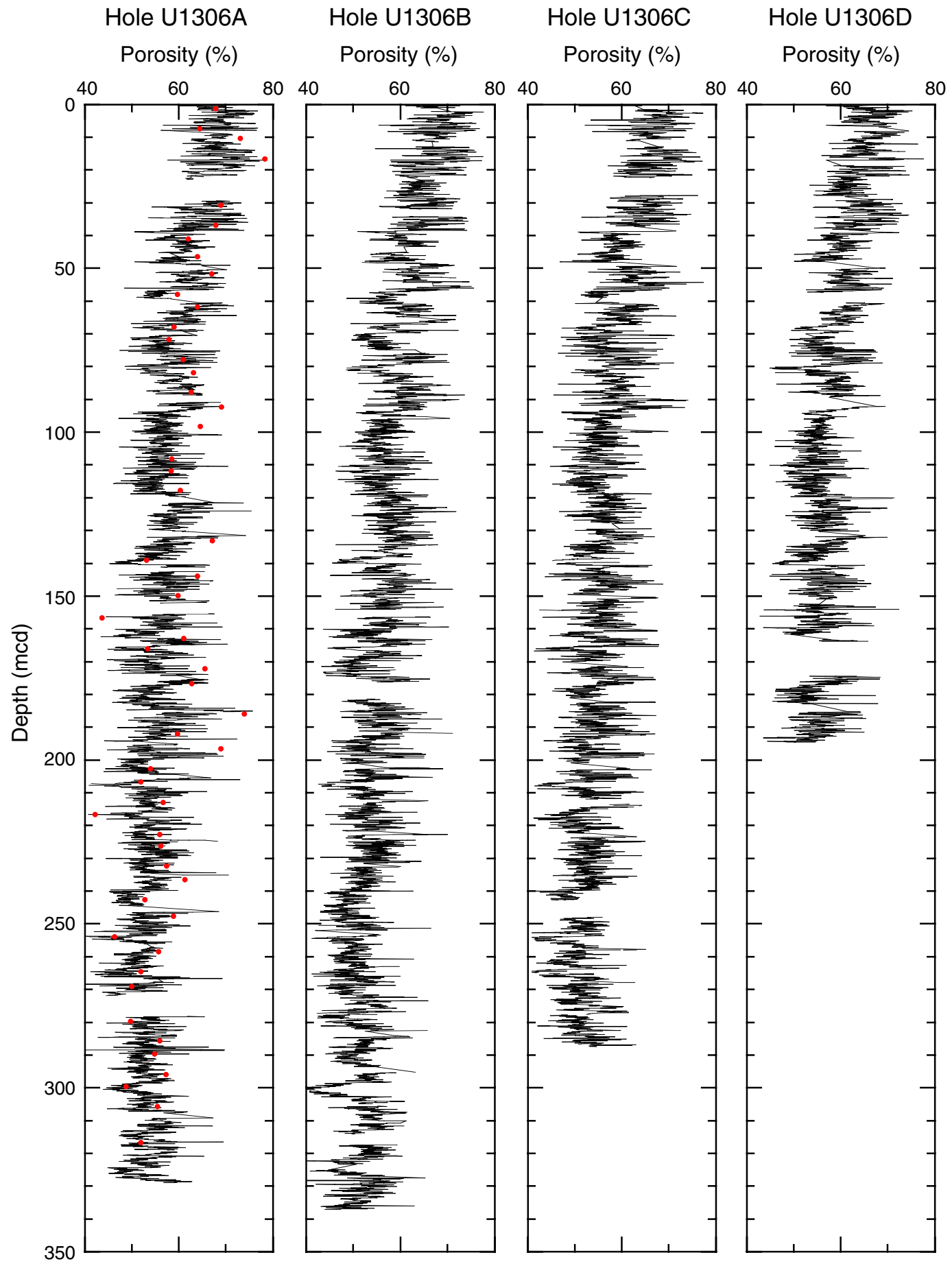


Figure F33. Combined plots of the smoothed spliced records of natural gamma ray (NGR), multisensor track magnetic susceptibility (MS), and gamma ray attenuation (GRA) density, Site U1306.

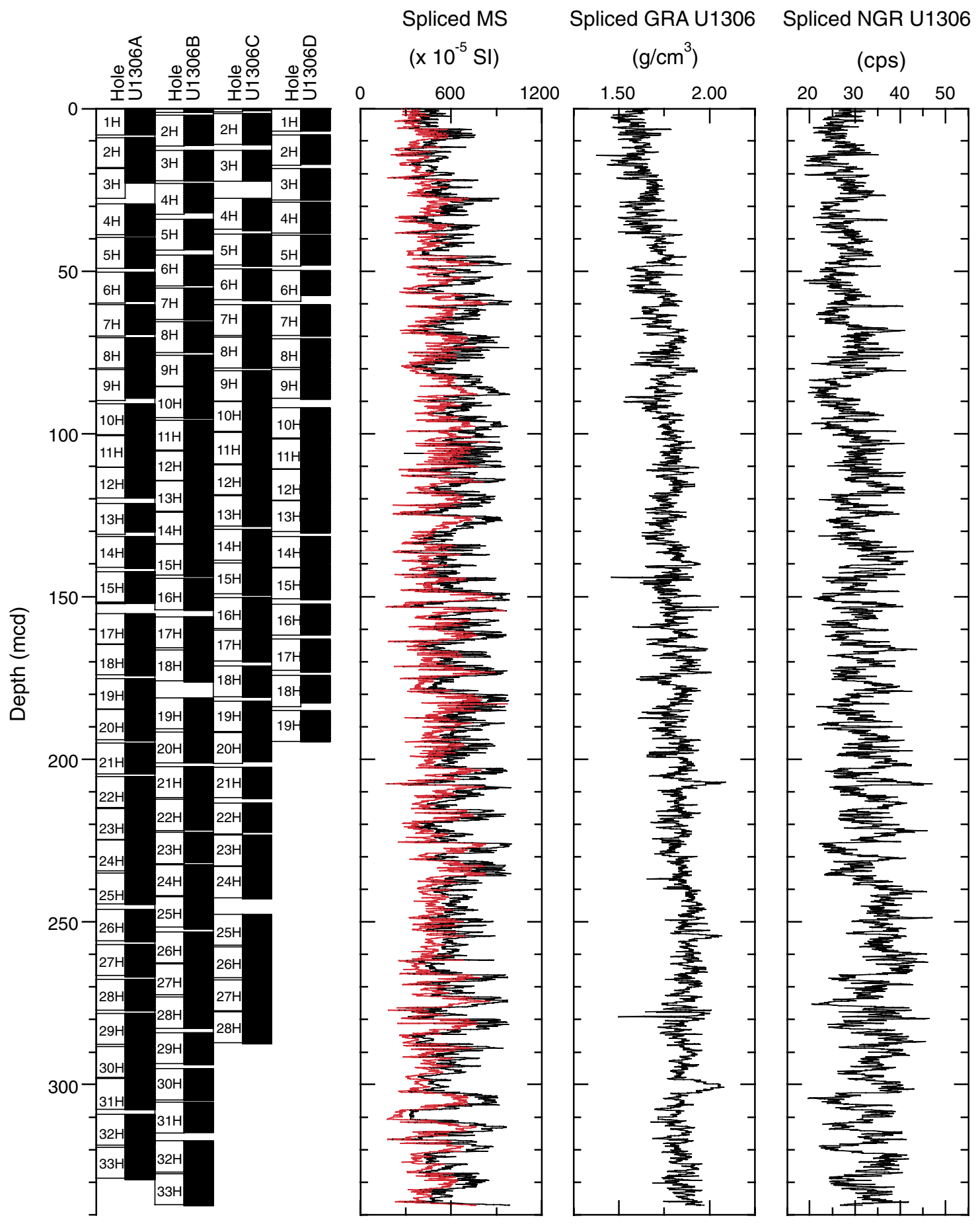


Table T1. Coring summary, Site U1306. (See table note. Continued on next three pages.)

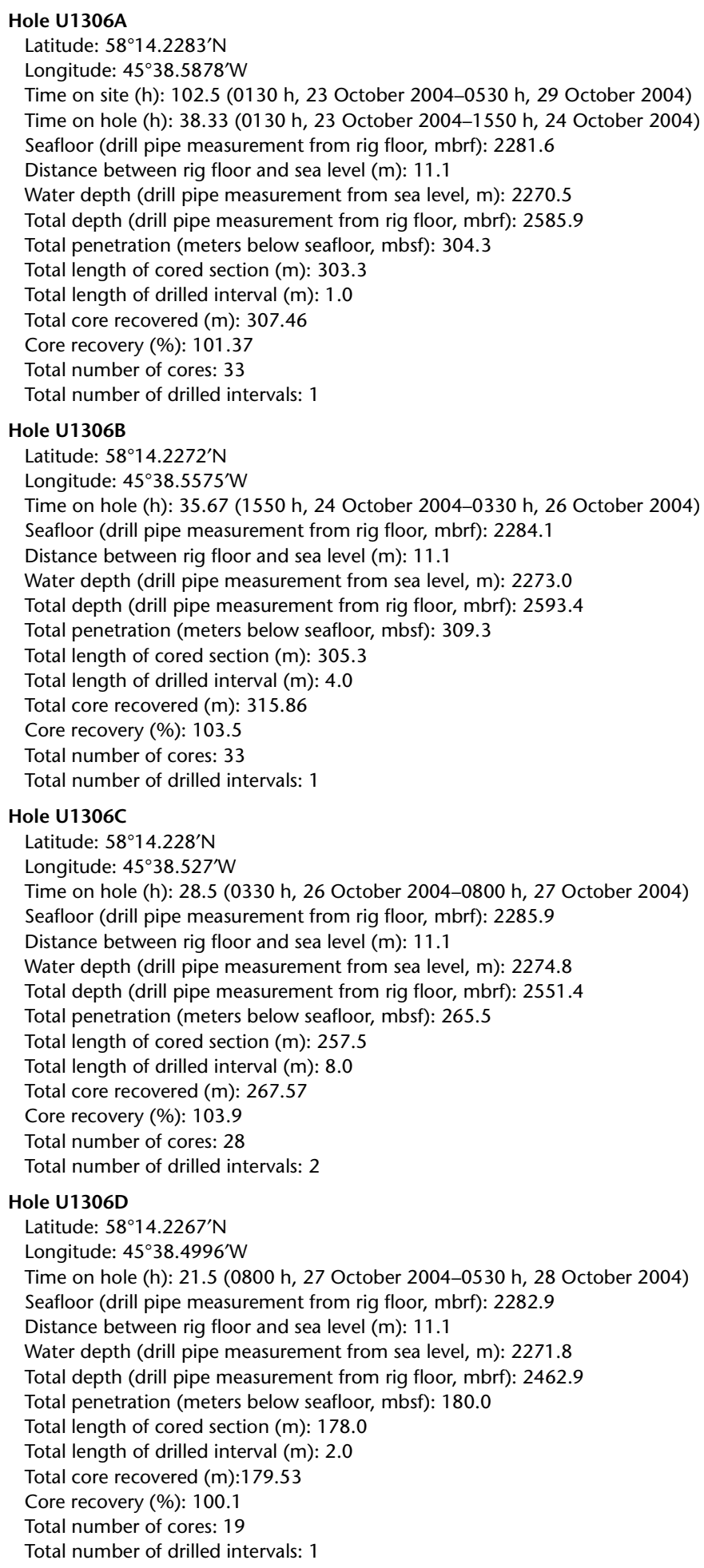


Table T1 (continued).

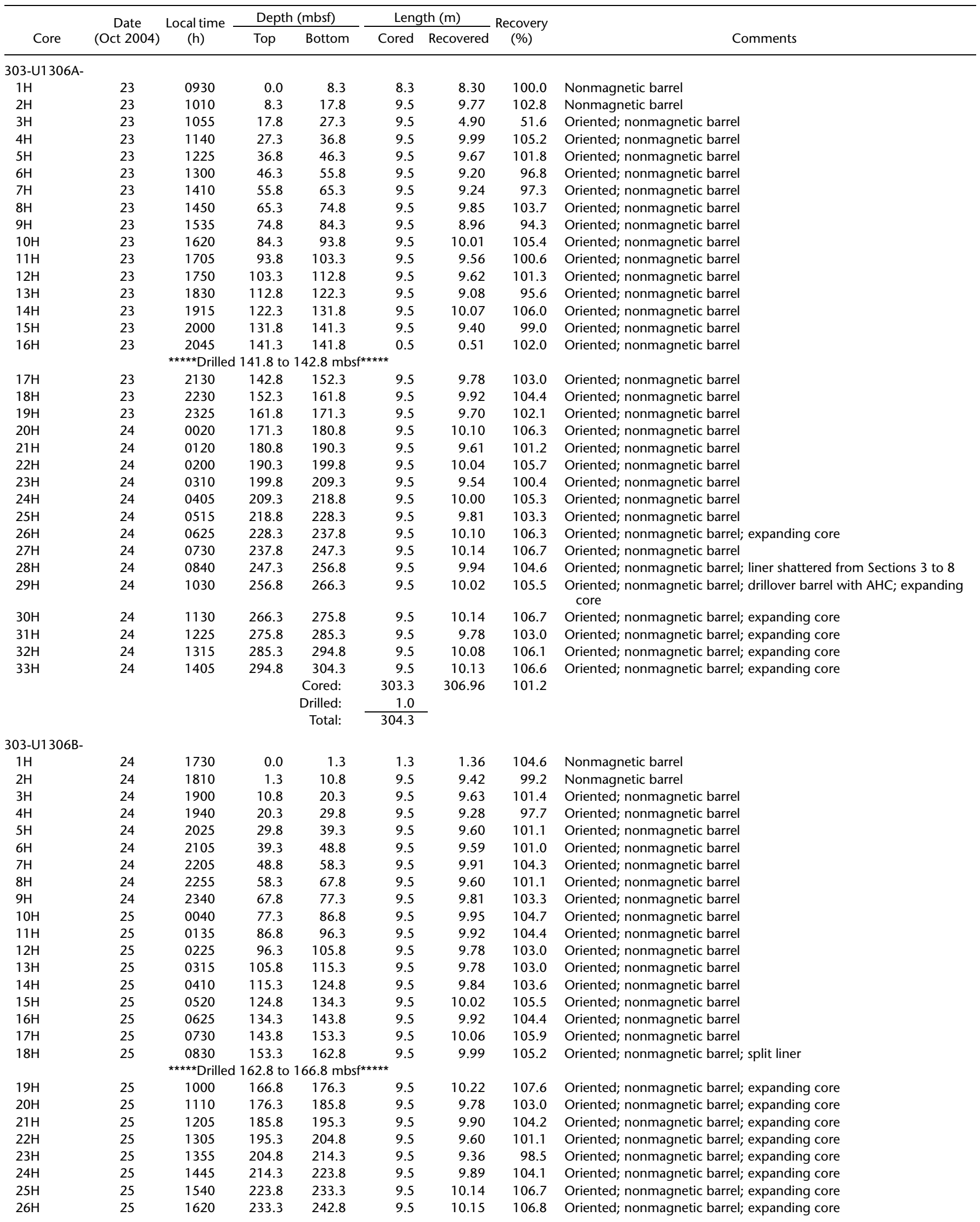


Table T1 (continued).

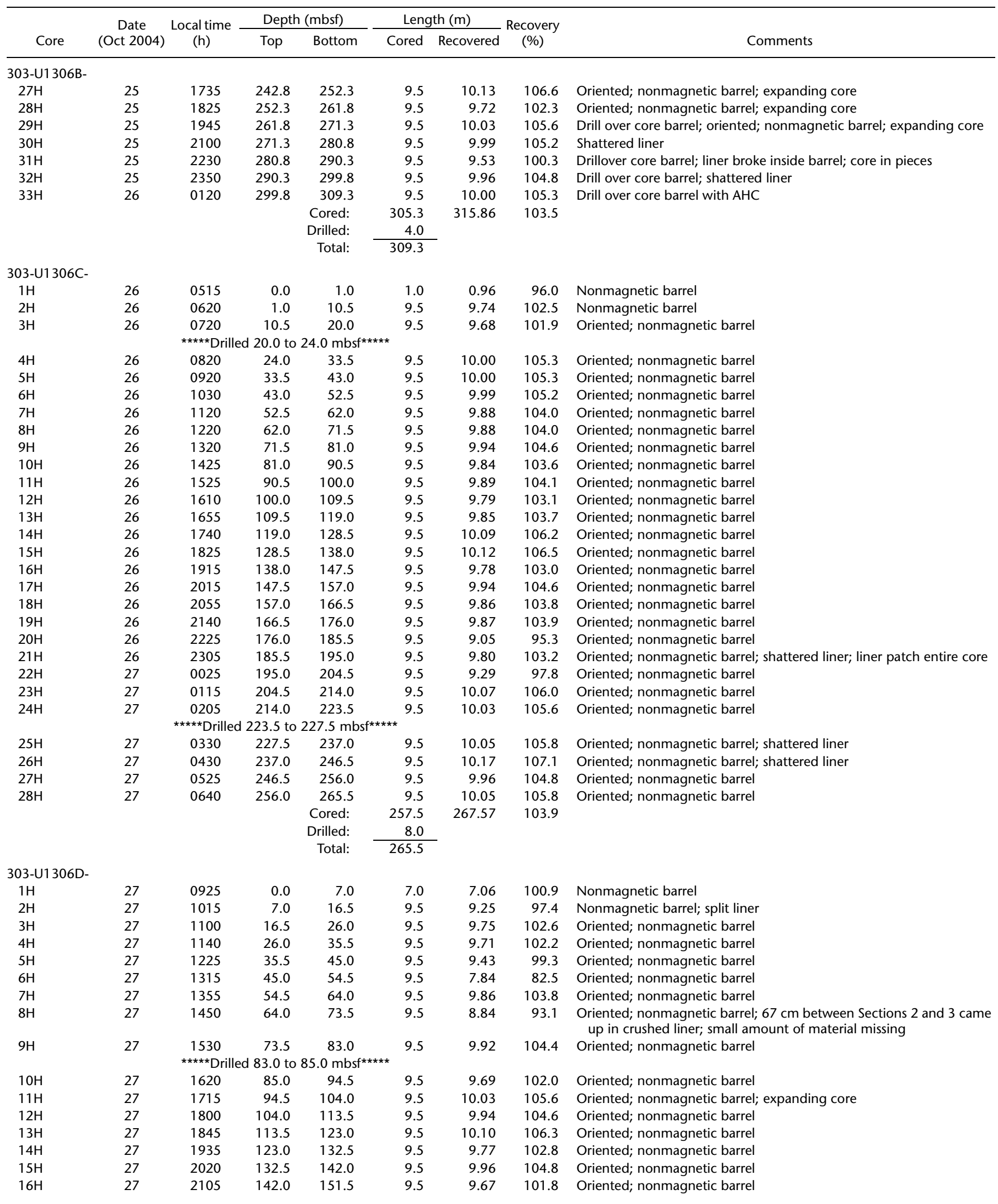


Table T1 (continued).

\begin{tabular}{|c|c|c|c|c|c|c|c|c|}
\hline \multirow[b]{2}{*}{ Core } & \multirow{2}{*}{$\begin{array}{c}\text { Date } \\
\text { (Oct 2004) }\end{array}$} & \multirow{2}{*}{$\begin{array}{l}\text { Local time } \\
\quad(h)\end{array}$} & \multicolumn{2}{|c|}{ Depth (mbsf) } & \multicolumn{2}{|c|}{ Length $(\mathrm{m})$} & \multirow{2}{*}{$\begin{array}{c}\text { Recovery } \\
\text { (\%) }\end{array}$} & \multirow[b]{2}{*}{ Comments } \\
\hline & & & Top & Bottom & Cored & Recovered & & \\
\hline \multicolumn{9}{|c|}{ 303-U1306D- } \\
\hline $17 \mathrm{H}$ & 27 & 2150 & 151.5 & 161.0 & 9.5 & 10.29 & 108.3 & $\begin{array}{l}\text { Oriented; nonmagnetic barrel; liners shattered while roughnecks } \\
\text { extracting core from barrel; entire core was transferred to split liner }\end{array}$ \\
\hline $18 \mathrm{H}$ & 27 & 2240 & 161.0 & 170.5 & 9.5 & 8.66 & 91.2 & Oriented; nonmagnetic barrel \\
\hline \multirow[t]{4}{*}{$19 \mathrm{H}$} & 27 & 2320 & 170.5 & 180.0 & 9.5 & 9.76 & 102.7 & Oriented; nonmagnetic barrel \\
\hline & & & & Cored: & 178.0 & 179.53 & 100.9 & \\
\hline & & & & Drilled: & 2.0 & & & \\
\hline & & & & Total: & 180.0 & & & \\
\hline
\end{tabular}

Note: $\mathrm{AHC}=$ active heave compensator $\mathrm{PHC}=$ passive heave compensator. 


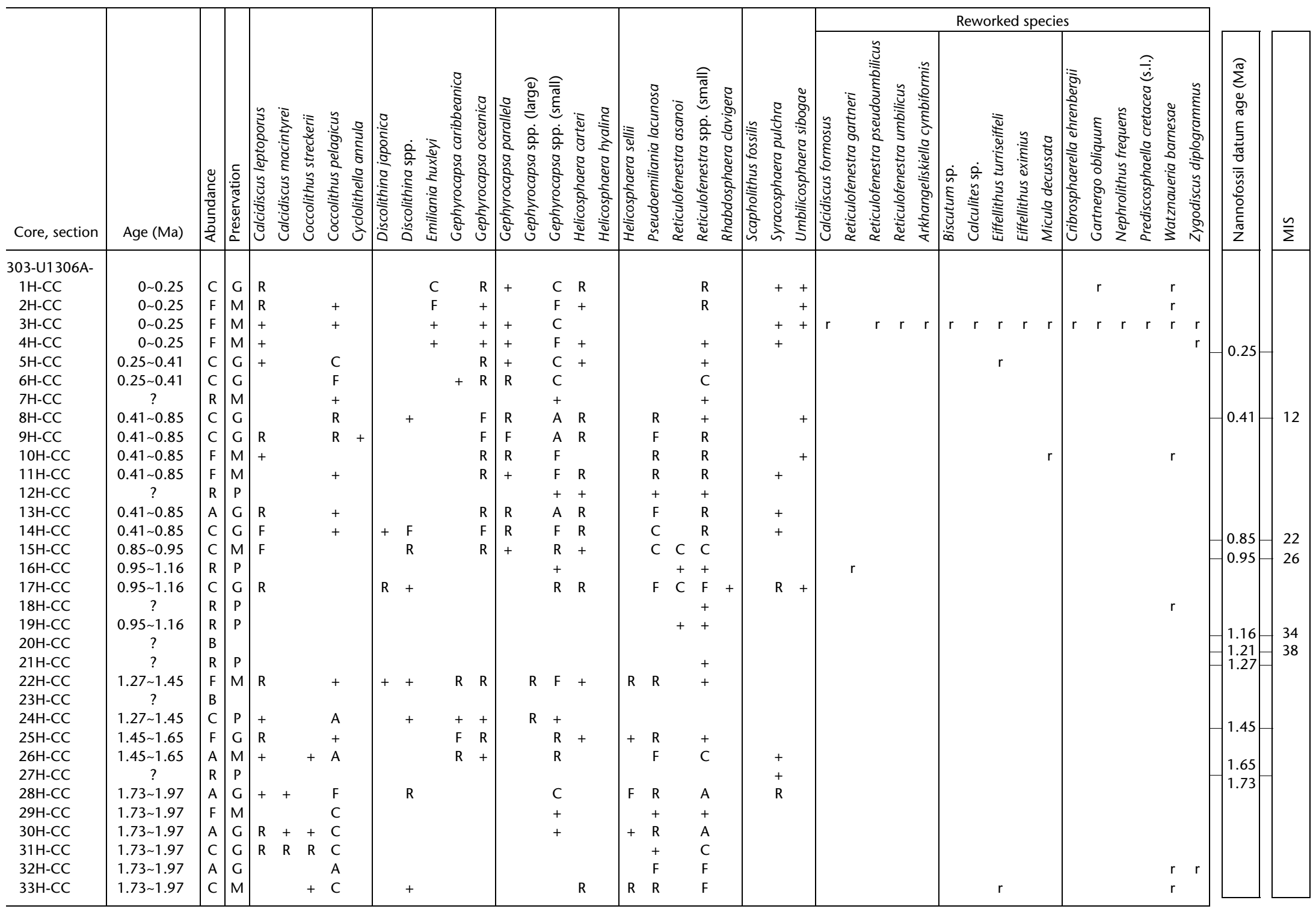

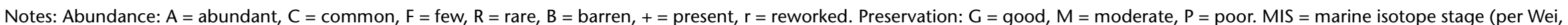
1993; Sato et al., 1999). 


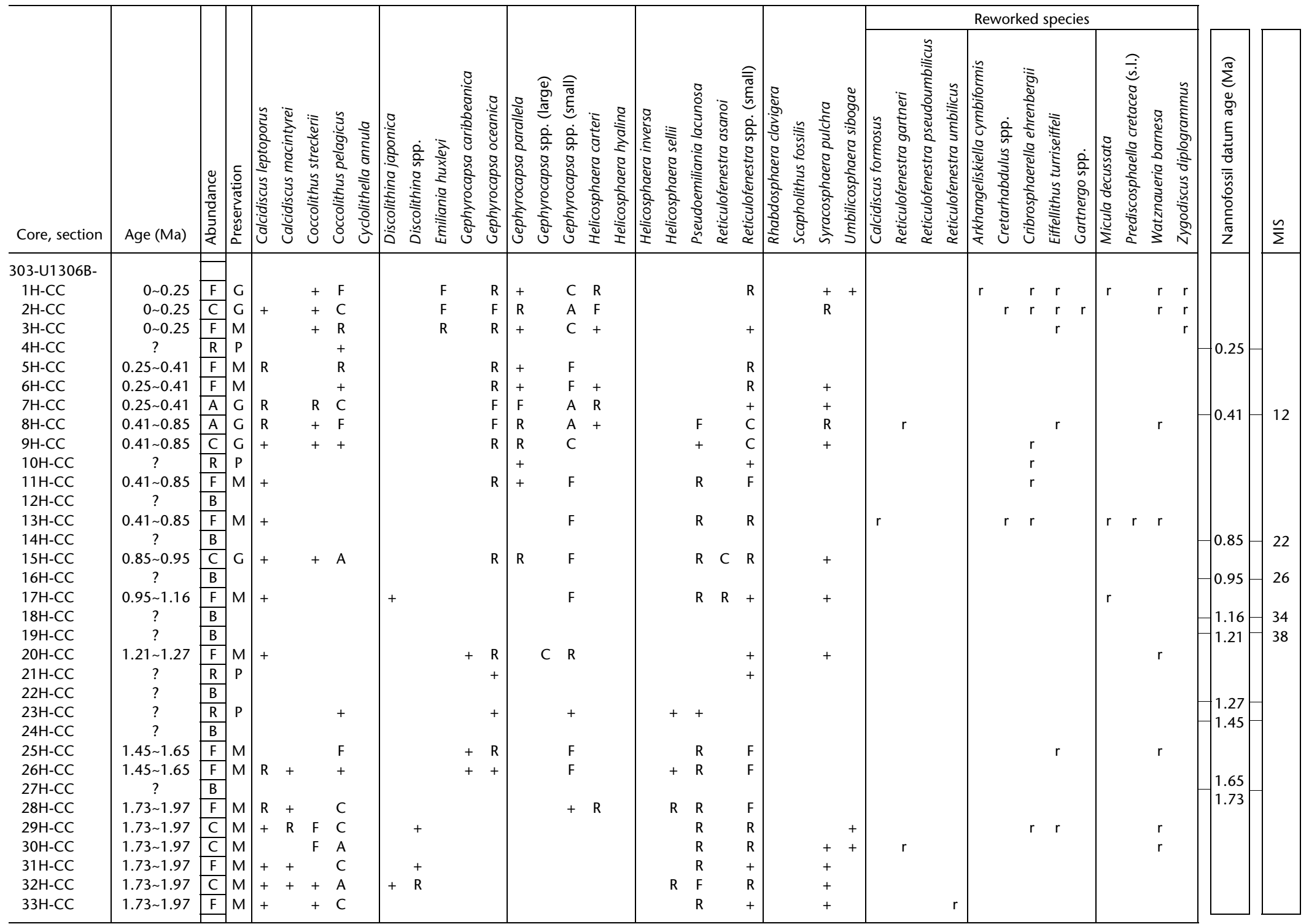

Notes: Abundance: $\mathrm{A}=$ abundant, $\mathrm{C}=$ common, $\mathrm{F}=$ few $\mathrm{R}=$ rare, $\mathrm{B}=$ barren, $+=$ present, $\mathrm{r}=$ reworked. Preservation: $\mathrm{G}=$ good, $\mathrm{M}=$ moderate, $\mathrm{P}=$ poor. $\mathrm{MIS}=$ marine isotope stage (per Wei, 1993; Sato et al., 1999). 


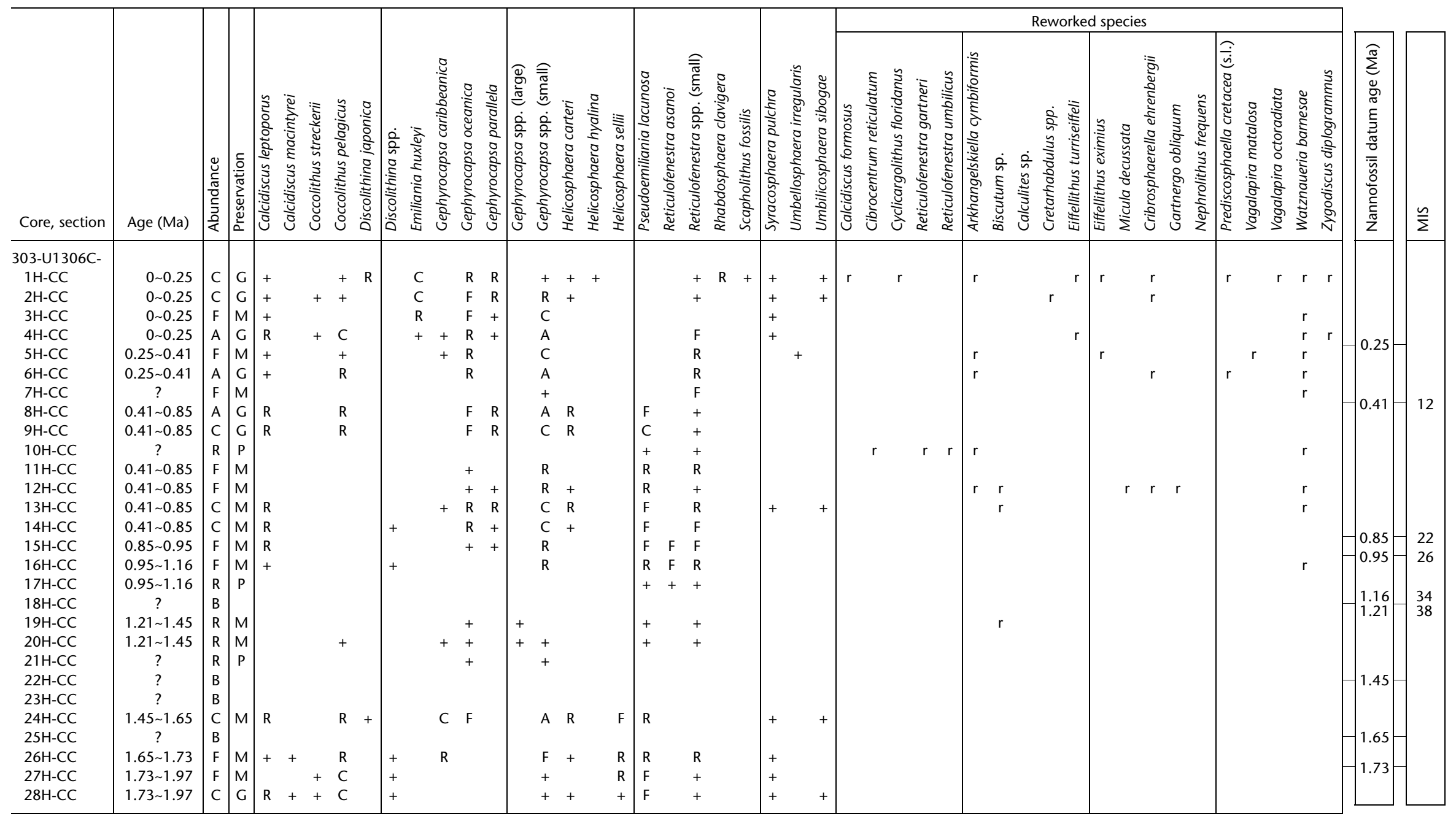

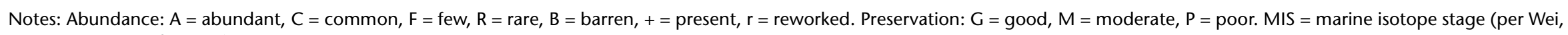
1993; Sato et al., 1999). 
Table T5. Distribution of calcareous nannofossils, Hole U1306D.

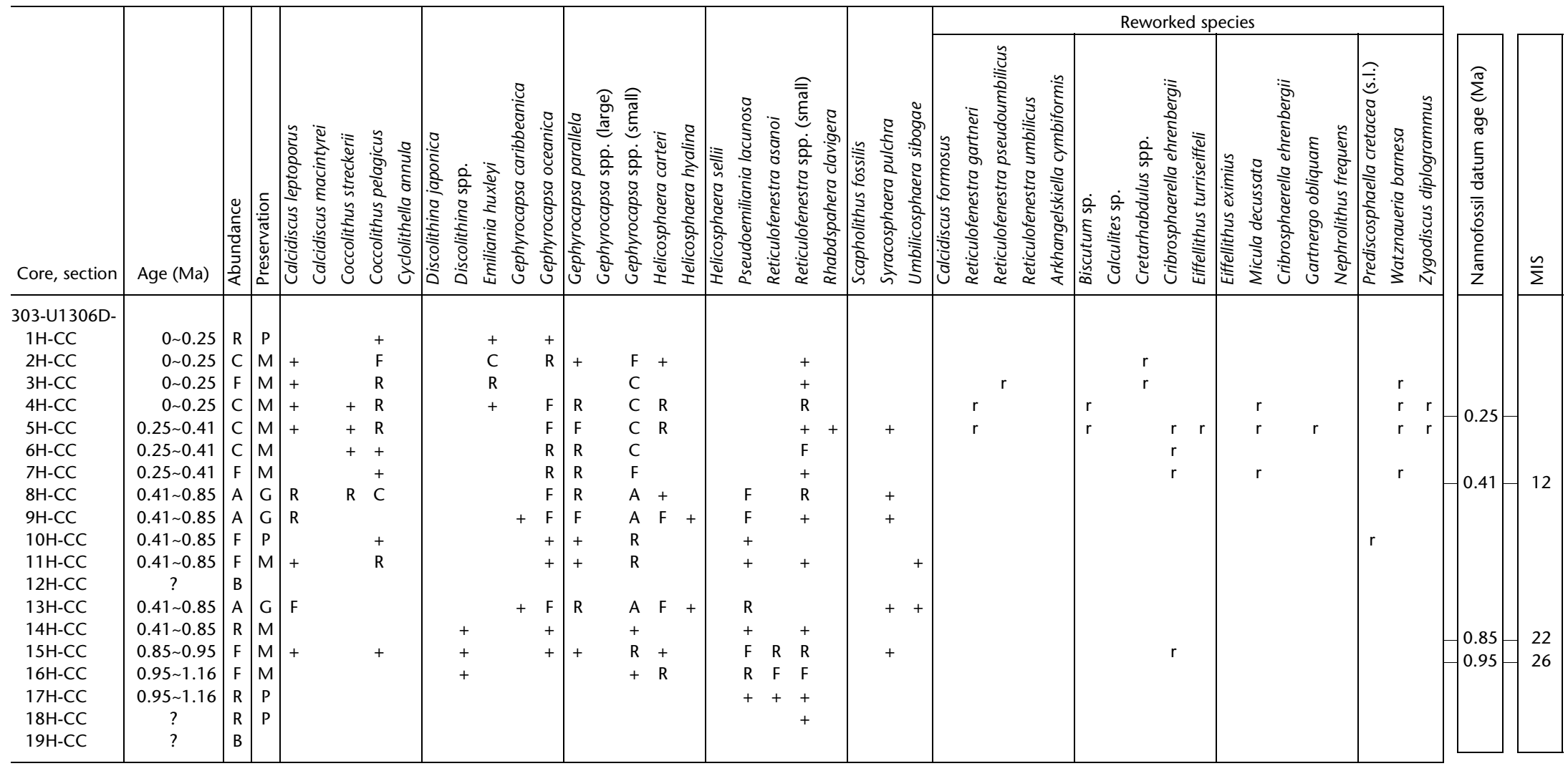

Notes: Abundance: $\mathrm{A}=$ abundant, $\mathrm{C}=$ common, $\mathrm{F}=$ few, $\mathrm{R}=$ rare, $\mathrm{B}=$ barren, $+=$ present, $\mathrm{r}=$ reworked. Preservation: $\mathrm{G}=$ good, $\mathrm{M}=$ moderate, $\mathrm{P}=$ poor. $\mathrm{MIS}=$ marine isotope stage (per Wei, 1993; Sato et al., 1999). 
Table T6. Distribution of planktonic foraminifers, Hole U1306A.

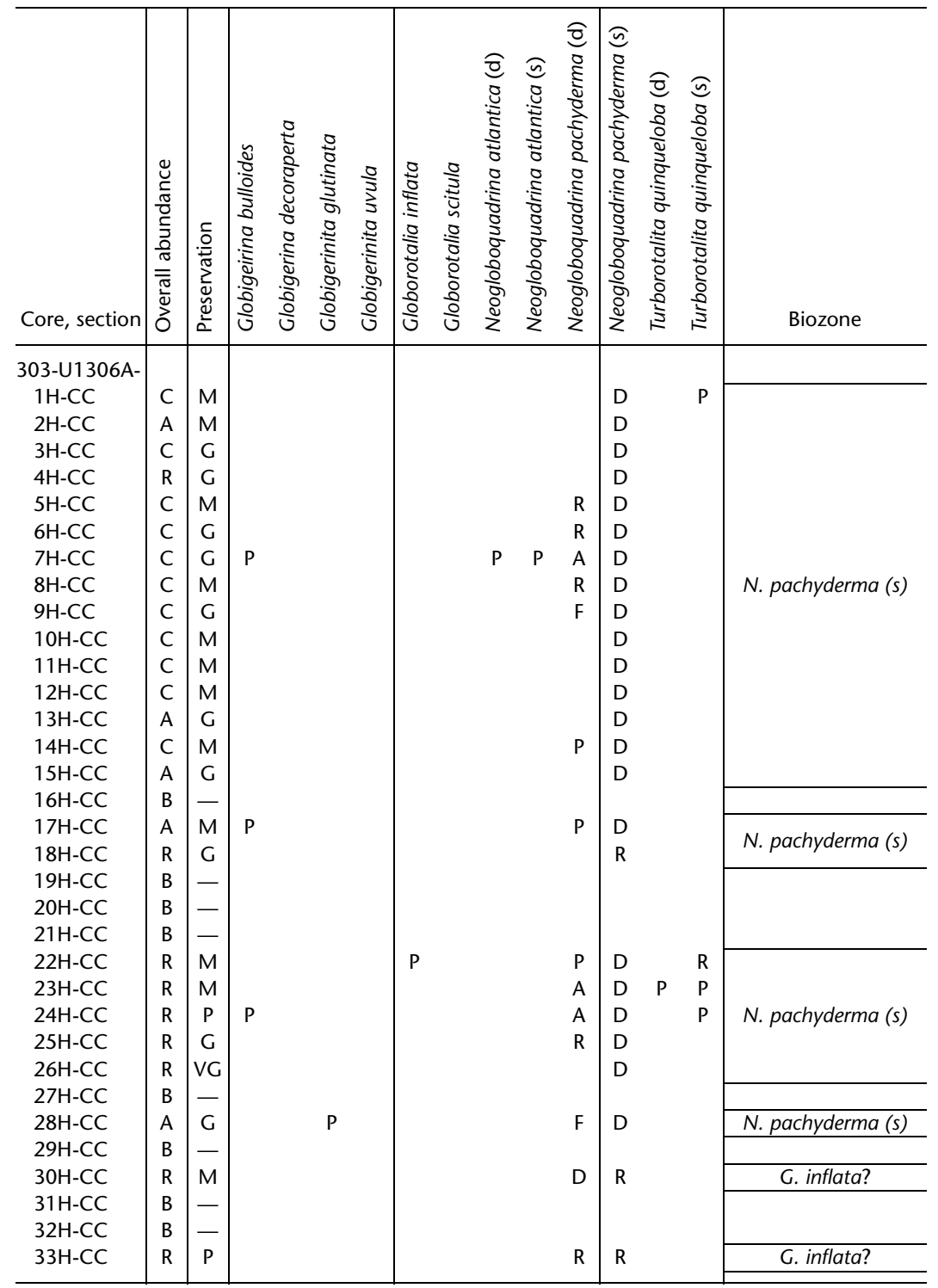

Notes: Globorotalia inflata was not observed in the sedimentary sequence at Site U1306, and the G. inflata and Globigerina bulloides Zones (Weaver and Clement, 1987) could not hence be verified by their zonal markers directly. Abundance: $D=$ dominant, $A=$ abundant, $C=$ common, $F=$ few, $R=$ rare, $P=$ present, $B=$ barren. Preservation: $V G=$ very good, $G=$ good, $M=$ moderate, $P=$ poor (see "Foraminifers" in the "Site U1302-U1308 methods" chapter). $d=$ dextral, $s=$ sinistral. 
Table T7. Distribution of planktonic foraminifers, Hole U1306B.

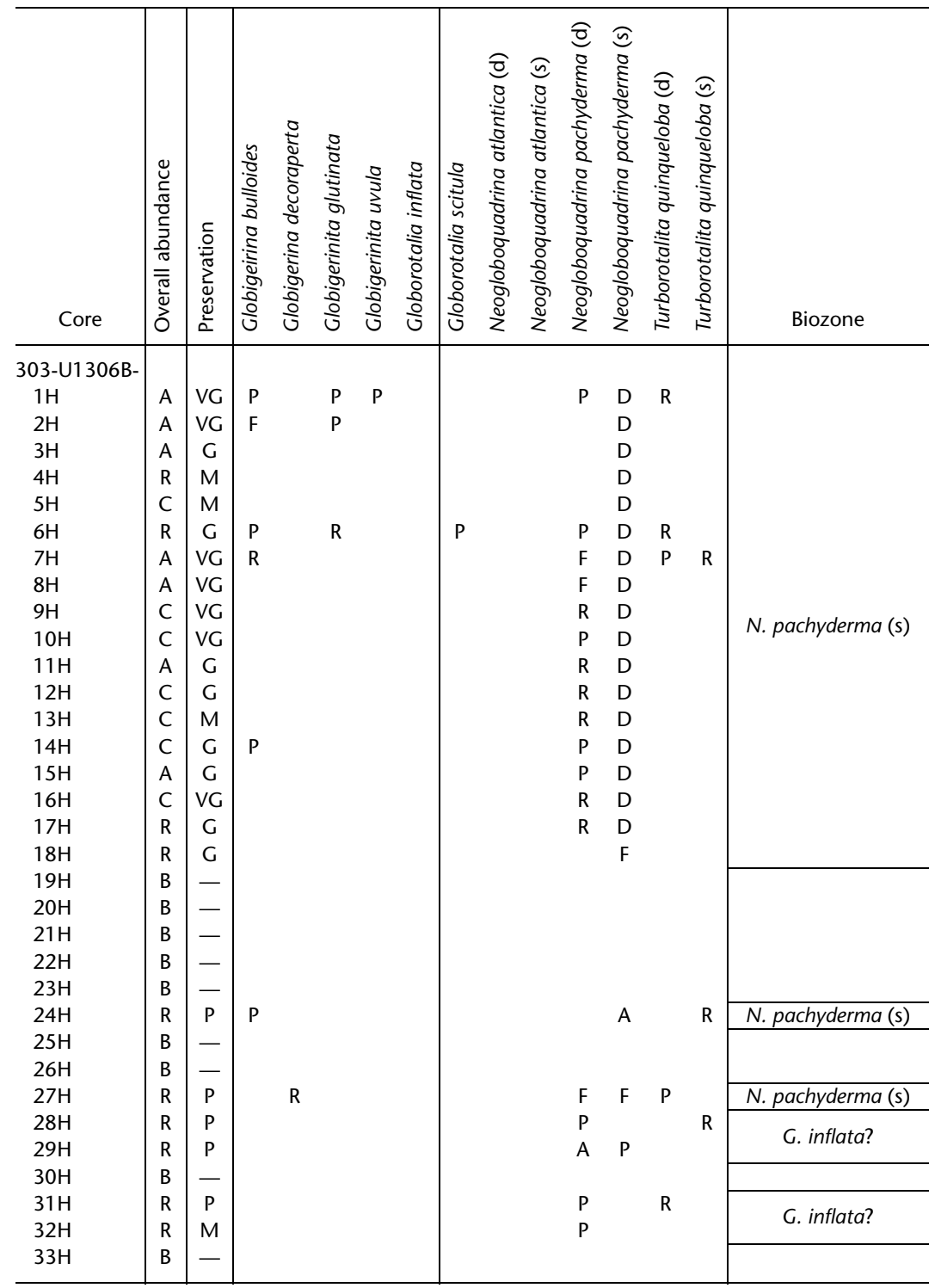

Notes: Abundance: $D=$ dominant, $A=$ abundant, $C=$ common, $F=$ few, $R=$ rare, $P=$ present, $B=$ barren. Preservation: VG $=$ very good, $G=$ good, $M=$ moderate, $P=$ poor (see "Foraminifers" in the "Site U1302-U1308 methods" chapter). $d=$ dextral, $s=$ sinistral. 
Table T8. Distribution of planktonic foraminifers, Hole U1306C.

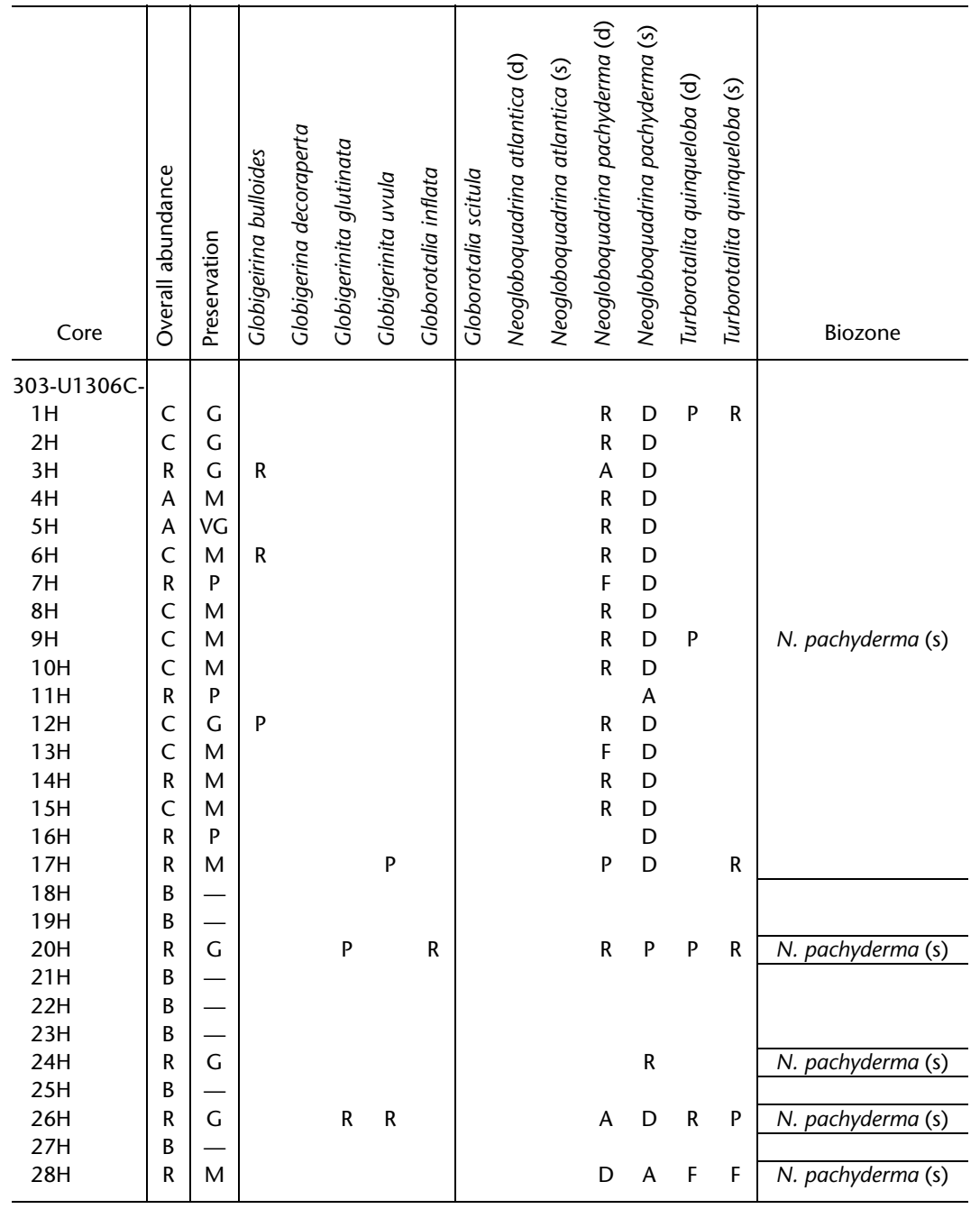

Notes: Abundance: $\mathrm{D}=$ dominat, $\mathrm{A}=$ abundant $\mathrm{C}=$ common, $\mathrm{F}=$ few $\mathrm{R}=$ rare, $\mathrm{P}=$ present, $\mathrm{B}=$ barren. Preservation: $\mathrm{VG}=$ very good, $\mathrm{G}=$ good, $\mathrm{M}=$ moderate, $\mathrm{P}=$ poor (see "Foraminifers" in the "Site U1302-U1308 methods" chapter). $\mathrm{d}=$ dextral, $\mathrm{s}=$ sinistral. 
Table T9. Distribution of planktonic foraminifers, Hole U1306D.

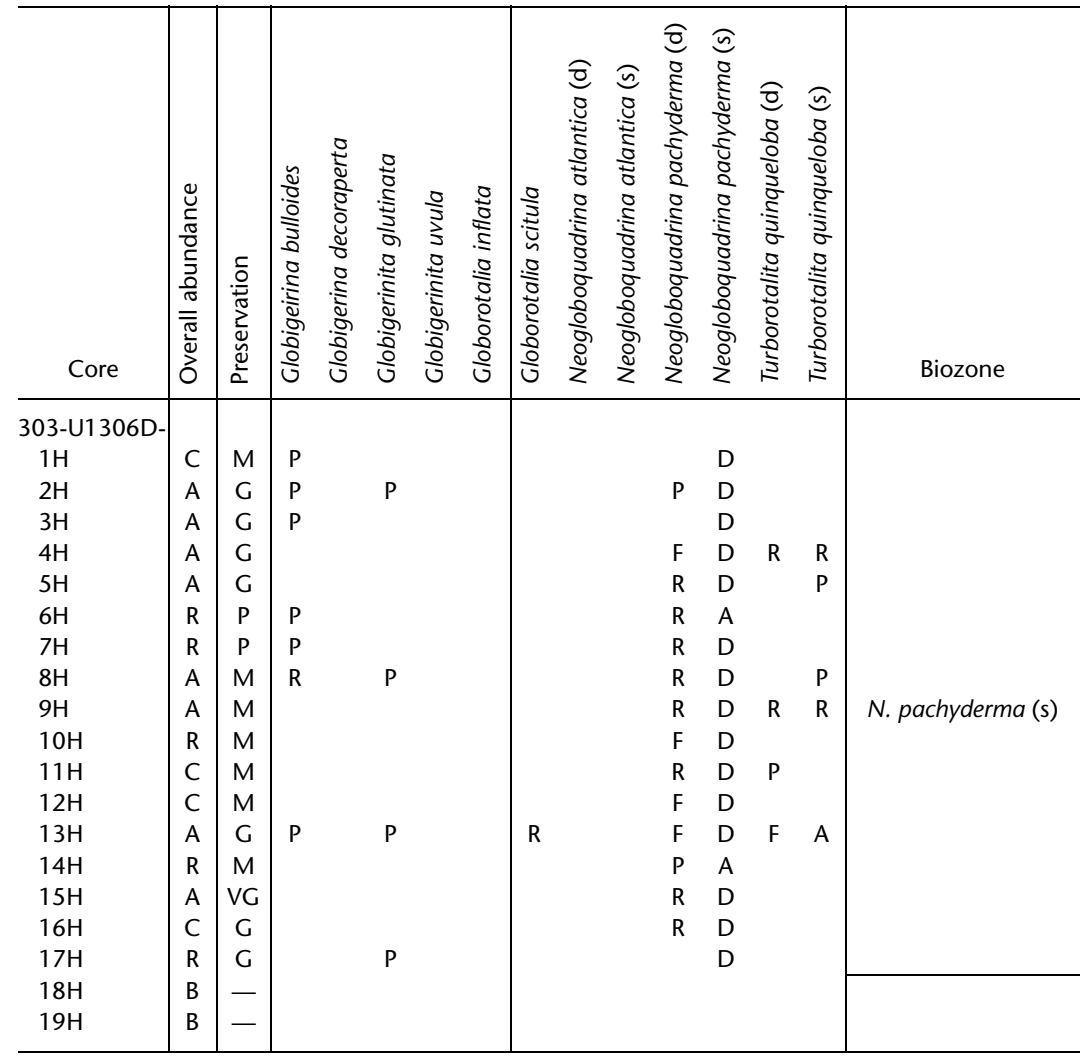

Notes: Abundance: $\mathrm{D}=$ dominat, $\mathrm{A}=$ abundant $\mathrm{C}=$ common, $\mathrm{F}=$ few $\mathrm{R}=$ rare, $\mathrm{P}=$ present, $\mathrm{B}=$ barren. Preservation: $\mathrm{VG}=$ very good, $\mathrm{G}=$ good, $\mathrm{M}=$ moderate, $\mathrm{P}=$ poor (see "Foraminifers" in the "Site U1302-U1308 methods" chapter). $d=$ dextral, $s=$ sinistral. 
Table T10. Distribution of benthic foraminifers, Holes U1306A, U1306B, U1306C, and U1306D. (See table notes. Continued on next page.)

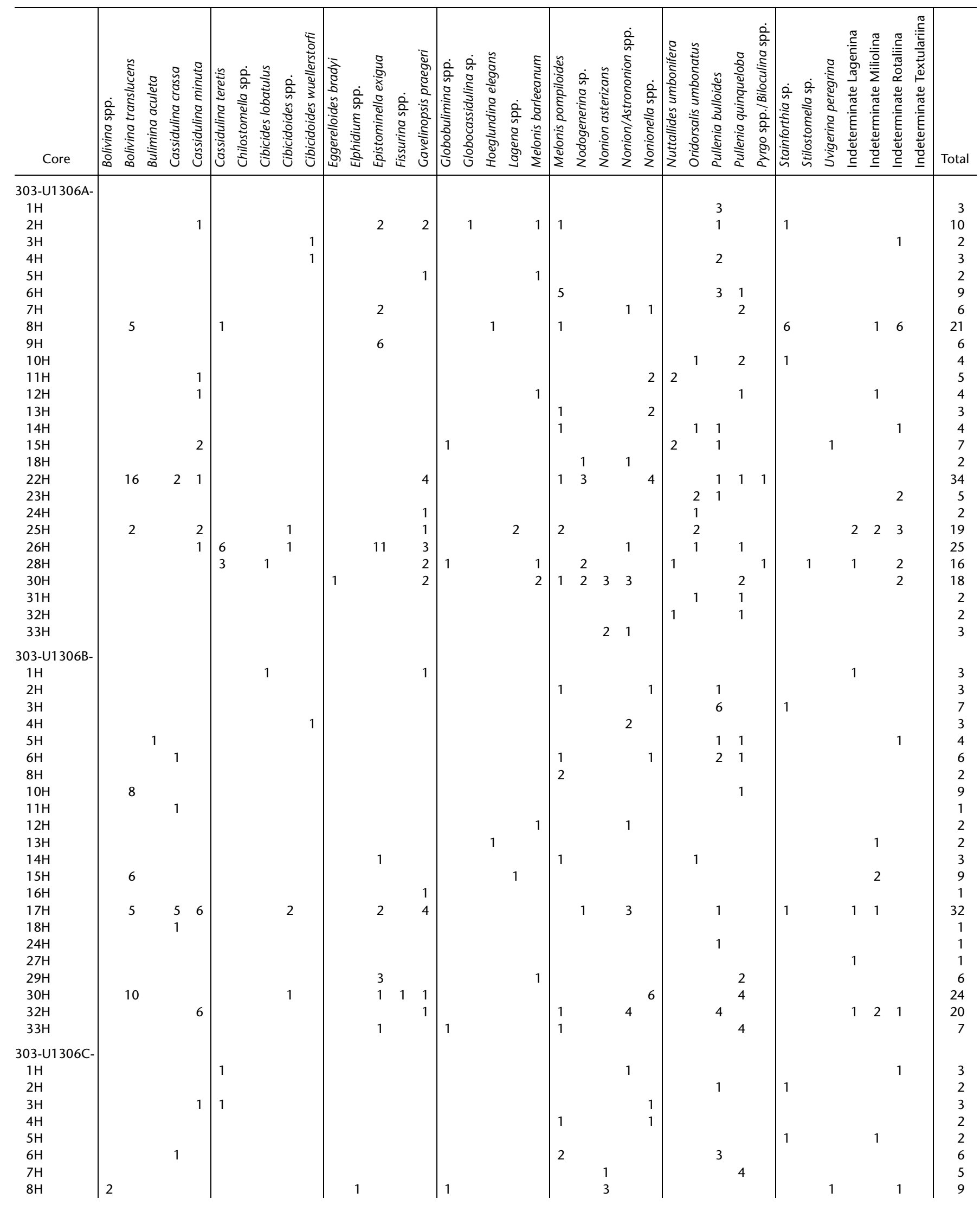


Table T10 (continued).

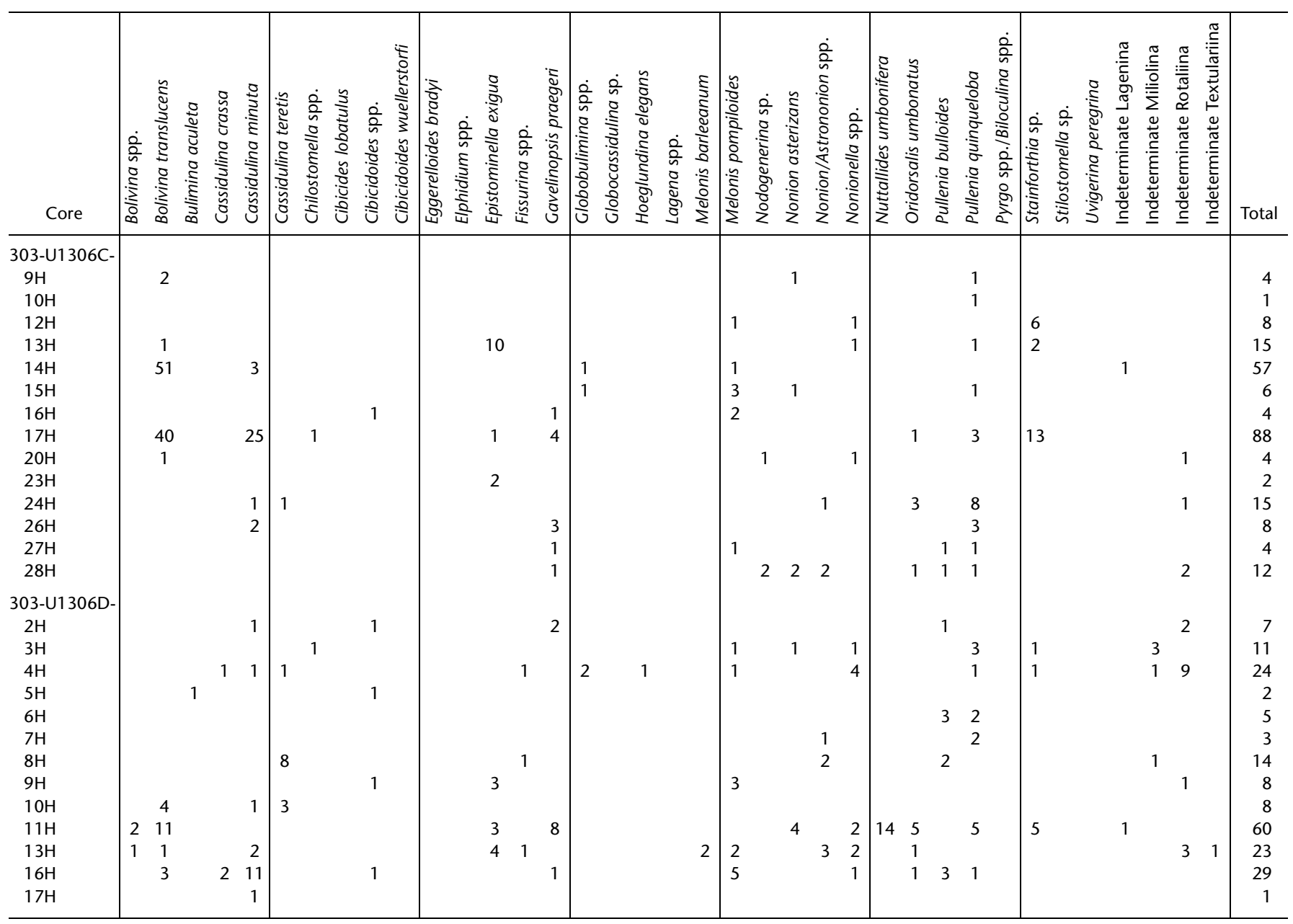

Notes: Numbers are absolute counts, which are not calibrated. Barren samples are not listed. 
Table T11. Distribution of diatoms and silicoflagellates, Hole U1306A. (See table notes. Continued on next five pages.)

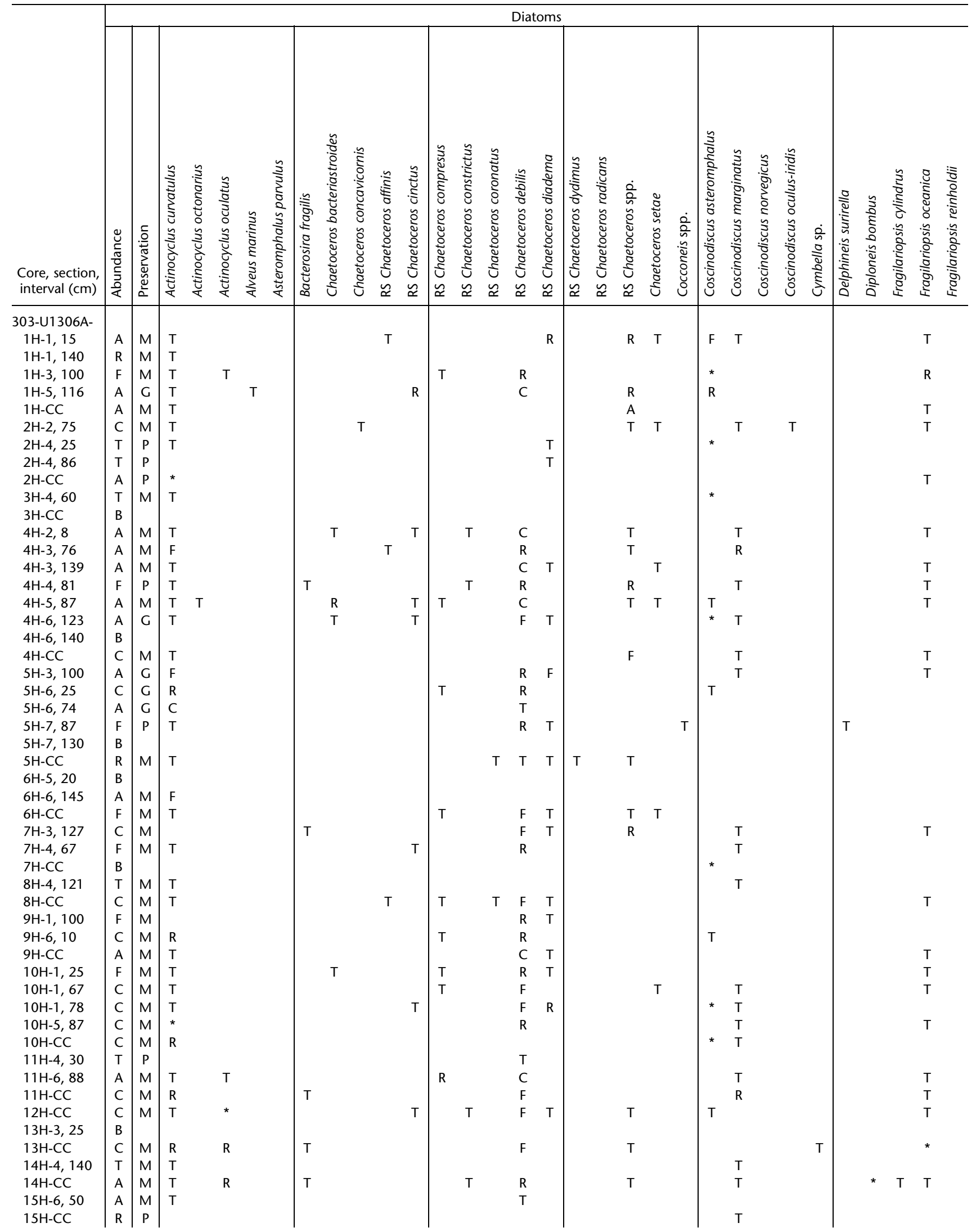


Table T11 (continued).

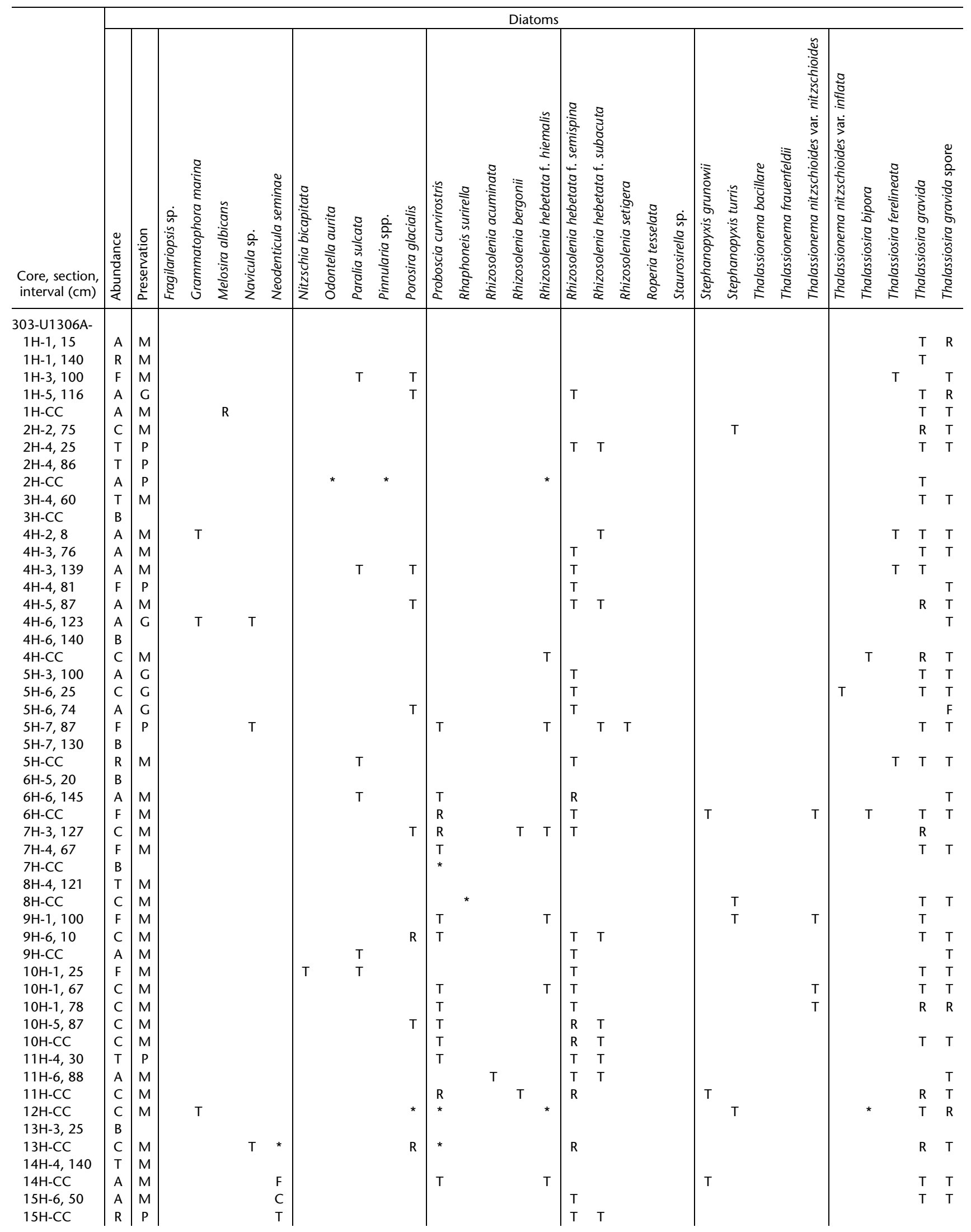


Table T11 (continued).

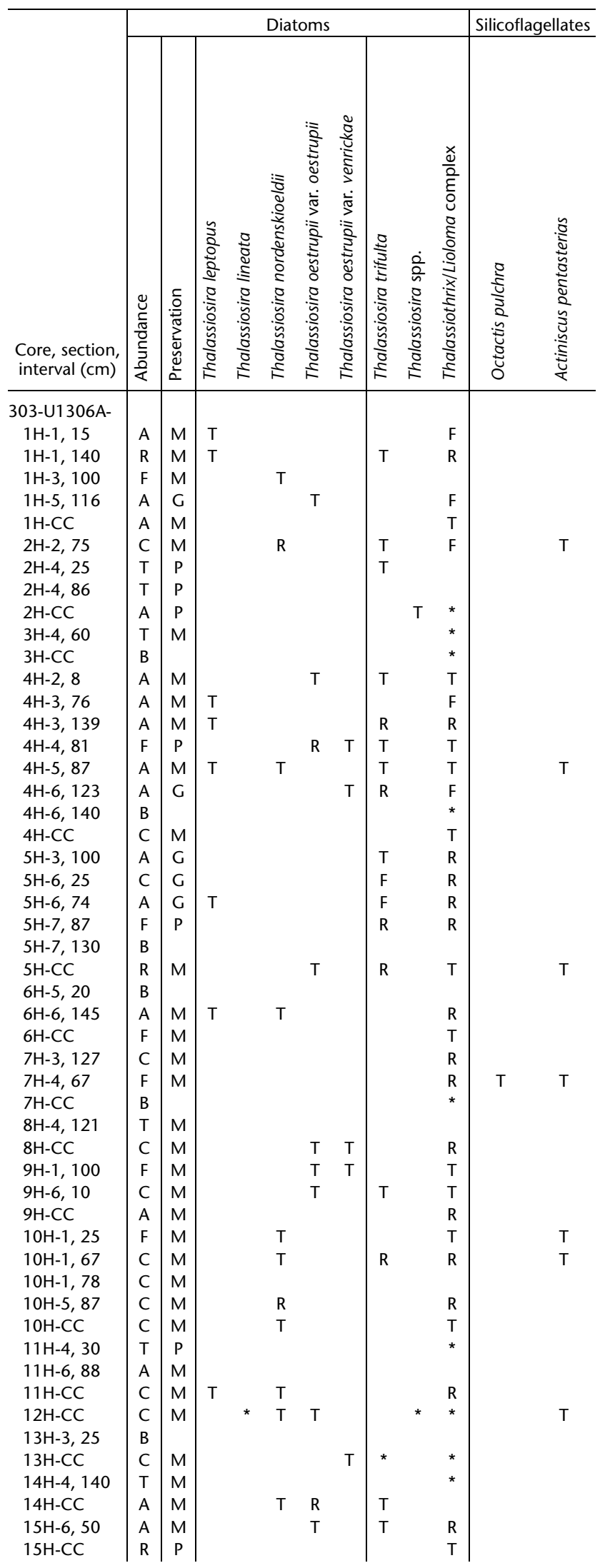


Table T11 (continued).

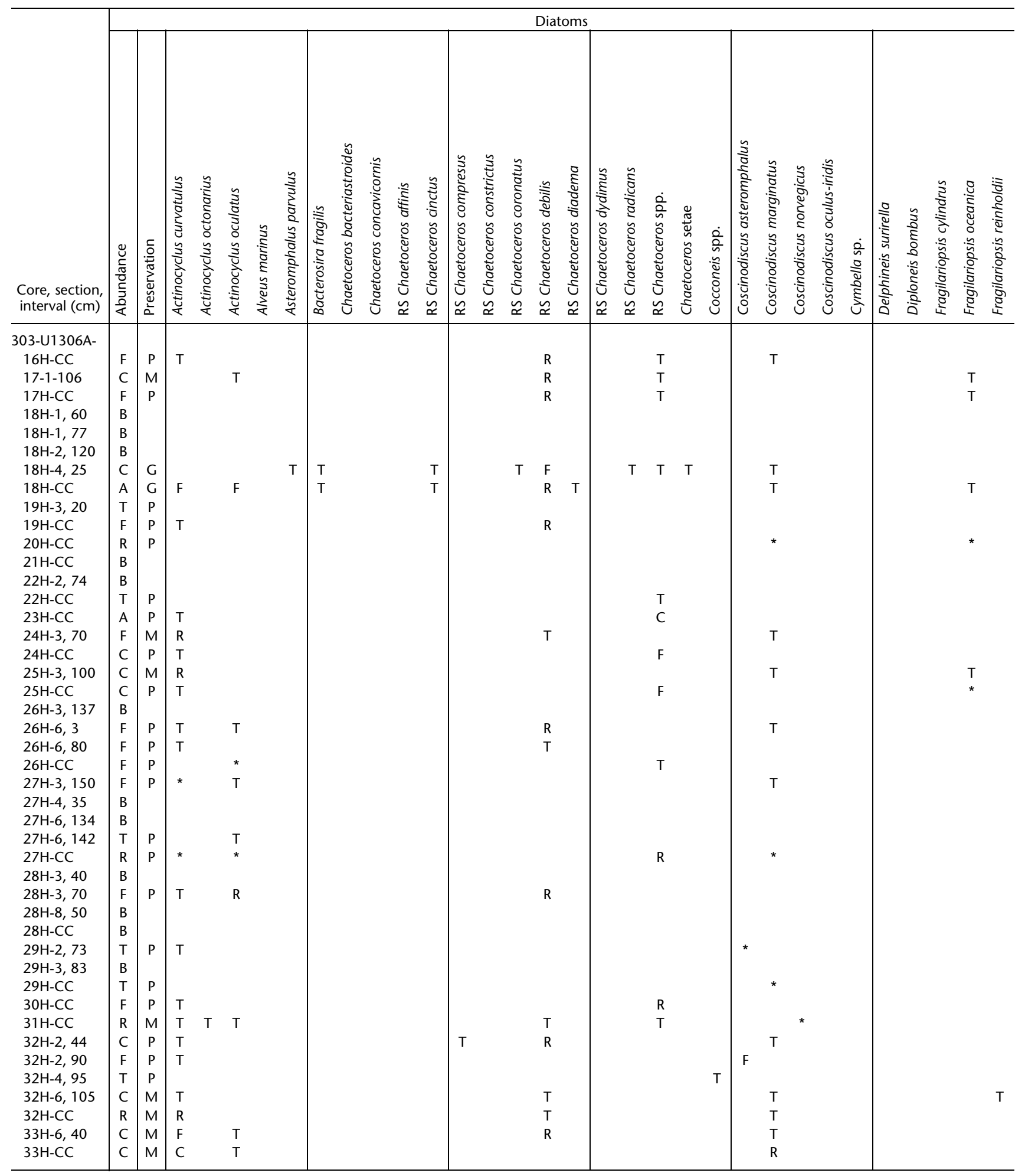

Notes: Abundance: $\mathrm{A}=$ abundant, $\mathrm{C}=$ common, $\mathrm{F}=$ few $\mathrm{R}=$ rare $\mathrm{T}=$ trace, $\mathrm{B}=$ barren. Preservation: $\mathrm{G}=$ good, $\mathrm{M}=\mathrm{moderate}, \mathrm{P}=$ poor. $\mathrm{RS}=$ resting spore. ${ }^{*}=$ fragment present. 
Table T11 (continued).

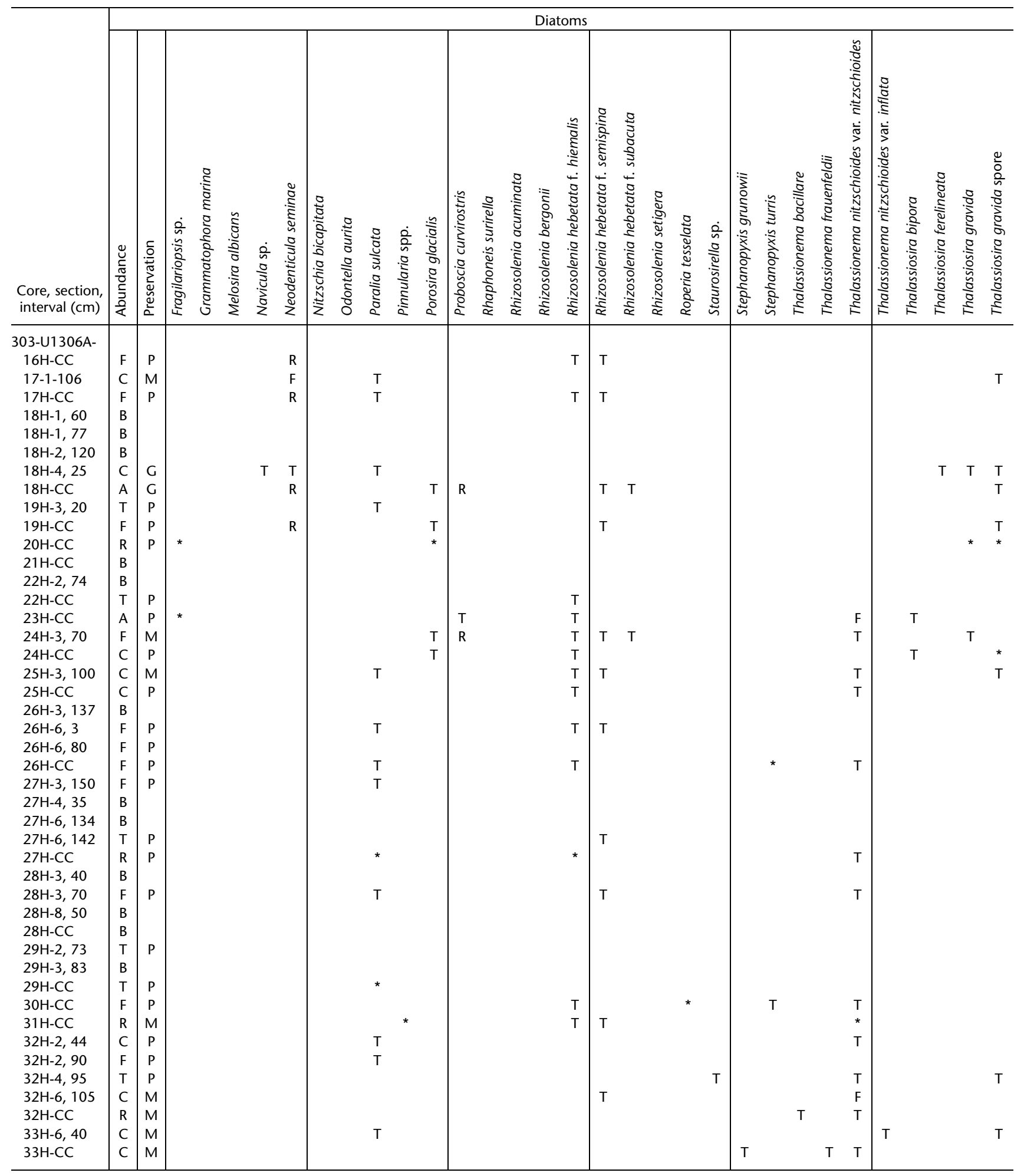


Table T11 (continued).

\begin{tabular}{|c|c|c|c|c|c|c|c|c|c|c|c|}
\hline \multirow[b]{2}{*}{$\begin{array}{l}\text { Core, section, } \\
\text { interval }(\mathrm{cm})\end{array}$} & \multicolumn{9}{|c|}{ Diatoms } & \multicolumn{2}{|c|}{ Silicoflagellates } \\
\hline & 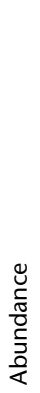 & 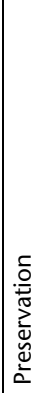 & 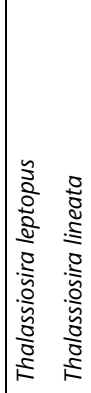 & 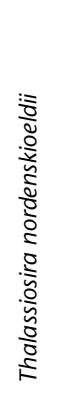 & 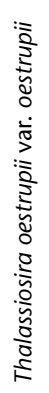 & 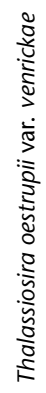 & 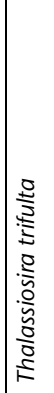 & 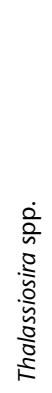 & 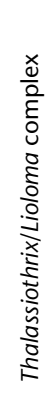 & 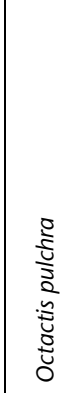 & 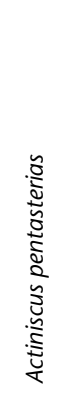 \\
\hline 303-U1306A- & & & & & & & & & & & \\
\hline $16 \mathrm{H}-\mathrm{CC}$ & $\mathrm{F}$ & $P$ & & & $\mathrm{~T}$ & & & & $\mathrm{~T}$ & & \\
\hline 17-1-106 & C & M & & $\mathrm{T}$ & & & & & & & \\
\hline $17 \mathrm{H}-\mathrm{CC}$ & $\mathrm{F}$ & $P$ & & & $\mathrm{~T}$ & & $\mathrm{~T}$ & & $\mathrm{~T}$ & & \\
\hline $18 \mathrm{H}-1,60$ & B & & & & & & & & & & \\
\hline $18 \mathrm{H}-1,77$ & B & & & & & & & & & & \\
\hline $18 \mathrm{H}-2,120$ & B & & & & & & & & & & \\
\hline $18 \mathrm{H}-4,25$ & C & G & & $\mathrm{T}$ & & & & & T & & \\
\hline $18 \mathrm{H}-\mathrm{CC}$ & A & G & & $\mathrm{T}$ & & & & & $\mathrm{R}$ & & $\mathrm{T}$ \\
\hline $19 \mathrm{H}-3,20$ & $\mathrm{~T}$ & $P$ & & & & & & & * & & \\
\hline $19 \mathrm{H}-\mathrm{CC}$ & $\mathrm{F}$ & $P$ & & & $\mathrm{~T}$ & $\mathrm{~T}$ & & & T & & \\
\hline $20 \mathrm{H}-\mathrm{CC}$ & $\mathrm{R}$ & $\mathrm{P}$ & & & & & & & & & \\
\hline $21 \mathrm{H}-\mathrm{CC}$ & B & & & & & & & & & & \\
\hline $22 \mathrm{H}-2,74$ & B & & & & & & & & & & \\
\hline $22 \mathrm{H}-\mathrm{CC}$ & $\mathrm{T}$ & $\mathrm{P}$ & & & * & & & & * & & \\
\hline $23 \mathrm{H}-\mathrm{CC}$ & A & $P$ & & & & & & & $\mathrm{~T}$ & & \\
\hline $24 \mathrm{H}-3,70$ & $\mathrm{~F}$ & M & & $\mathrm{T}$ & $\mathrm{T}$ & & & & $\mathrm{T}$ & & \\
\hline $24 \mathrm{H}-\mathrm{CC}$ & C & $P$ & & & T & & & & T & & \\
\hline $25 \mathrm{H}-3,100$ & C & M & & & $\mathrm{F}$ & $\mathrm{T}$ & & & $\mathrm{T}$ & & \\
\hline $25 \mathrm{H}-\mathrm{CC}$ & C & $P$ & & & $\mathrm{~T}$ & & & * & & & \\
\hline $26 \mathrm{H}-3,137$ & B & & & & & & & & & & \\
\hline $26 \mathrm{H}-6,3$ & $\mathrm{~F}$ & $\mathrm{P}$ & & & $\mathrm{T}$ & $\mathrm{T}$ & & & $\mathrm{R}$ & & \\
\hline $26 \mathrm{H}-6,80$ & $\mathrm{~F}$ & $P$ & & $\mathrm{~T}$ & $\mathrm{~T}$ & & & & $\mathrm{R}$ & & \\
\hline $26 \mathrm{H}-\mathrm{CC}$ & $\mathrm{F}$ & $P$ & & & & & & & $T$ & & \\
\hline $27 \mathrm{H}-3,150$ & $\mathrm{~F}$ & $P$ & & & & $\mathrm{~T}$ & & & $\mathrm{~F}$ & & \\
\hline $27 \mathrm{H}-4,35$ & B & & & & & & & & & & \\
\hline $27 \mathrm{H}-6,134$ & B & & & & & & & & & & \\
\hline $27 \mathrm{H}-6,142$ & $\mathrm{~T}$ & $\mathrm{P}$ & & & & & & & & & \\
\hline $27 \mathrm{H}-\mathrm{CC}$ & $\mathrm{R}$ & $P$ & & & & & & & * & & \\
\hline $28 \mathrm{H}-3,40$ & B & & & & & & & & & & \\
\hline $28 \mathrm{H}-3,70$ & $\mathrm{~F}$ & $\mathrm{P}$ & & & & & & & $\mathrm{T}$ & & \\
\hline $28 \mathrm{H}-8,50$ & B & & & & & & & & & & \\
\hline $28 \mathrm{H}-\mathrm{CC}$ & B & & & & & & & & & & \\
\hline $29 \mathrm{H}-2,73$ & $\mathrm{~T}$ & $P$ & & & & & & & & & \\
\hline $29 \mathrm{H}-3,83$ & B & & & & & & & & & & \\
\hline $29 \mathrm{H}-\mathrm{CC}$ & $\mathrm{T}$ & $\mathrm{P}$ & & & & & & & & & \\
\hline $30 \mathrm{H}-\mathrm{CC}$ & $\mathrm{F}$ & $P$ & & & $\mathrm{~T}$ & & & & * & & \\
\hline $31 \mathrm{H}-\mathrm{CC}$ & $\mathrm{R}$ & M & & & & & & & & & \\
\hline $32 \mathrm{H}-2,44$ & C & $\mathrm{P}$ & & & $\mathrm{T}$ & & & & & & \\
\hline $32 \mathrm{H}-2,90$ & $\mathrm{~F}$ & $\mathrm{P}$ & & & & & & & & & \\
\hline $32 \mathrm{H}-4,95$ & $\mathrm{~T}$ & $P$ & & & & & & & & & \\
\hline $32 \mathrm{H}-6,105$ & C & M & & & $\mathrm{T}$ & & & & & & \\
\hline $32 \mathrm{H}-\mathrm{CC}$ & $\mathrm{R}$ & M & & & $\mathrm{T}$ & & & & T & & \\
\hline $33 \mathrm{H}-6,40$ & C & M & & & $\mathrm{T}$ & & & & $\mathrm{T}$ & & \\
\hline $33 \mathrm{H}-\mathrm{CC}$ & C & M & & & $\mathrm{T}$ & & & & & & \\
\hline
\end{tabular}


Table T12. Distribution of diatoms and silicoflagellates, Hole U1306B. (See table notes. Continued on next five pages.)

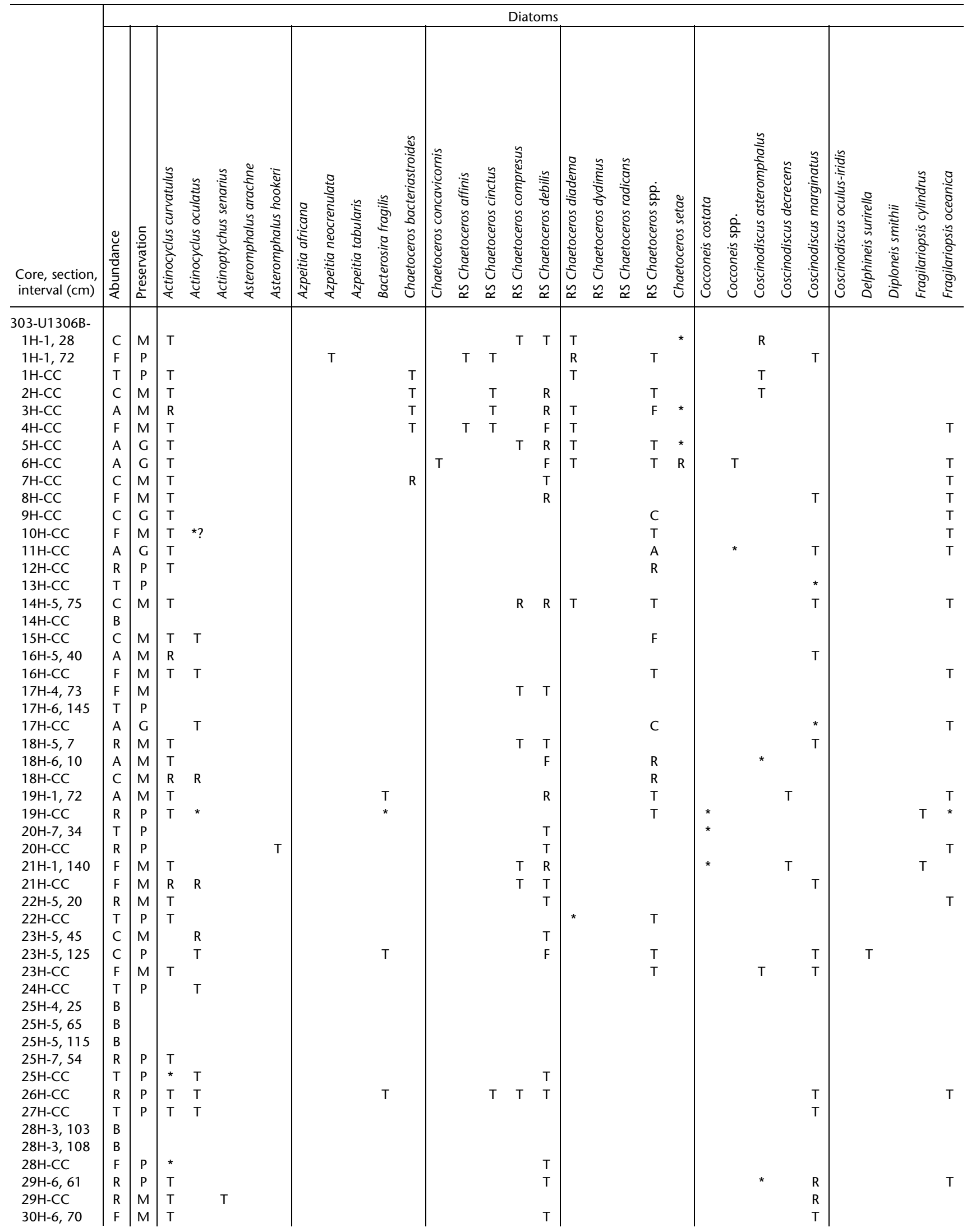


Table T12 (continued).

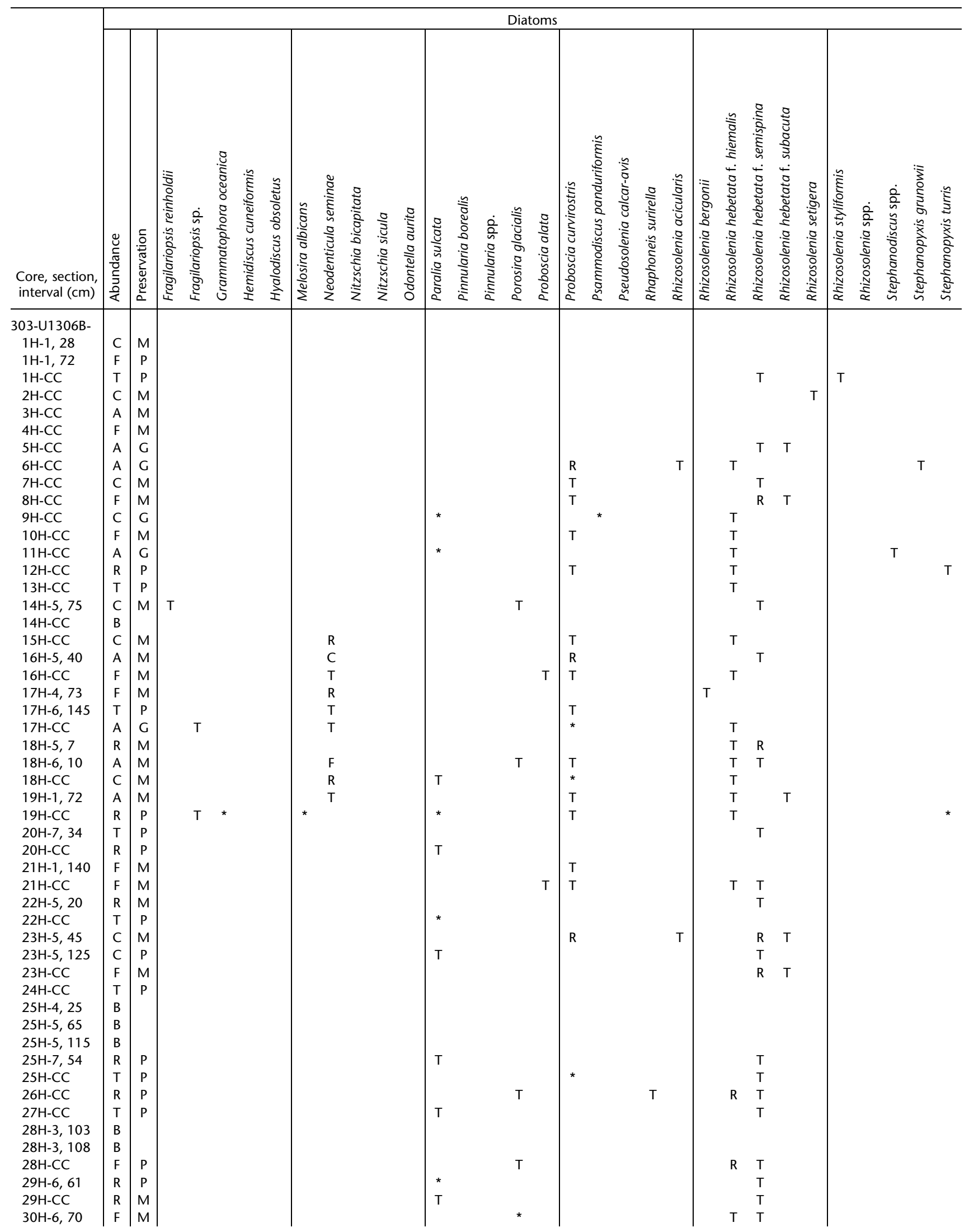


Table T12 (continued).

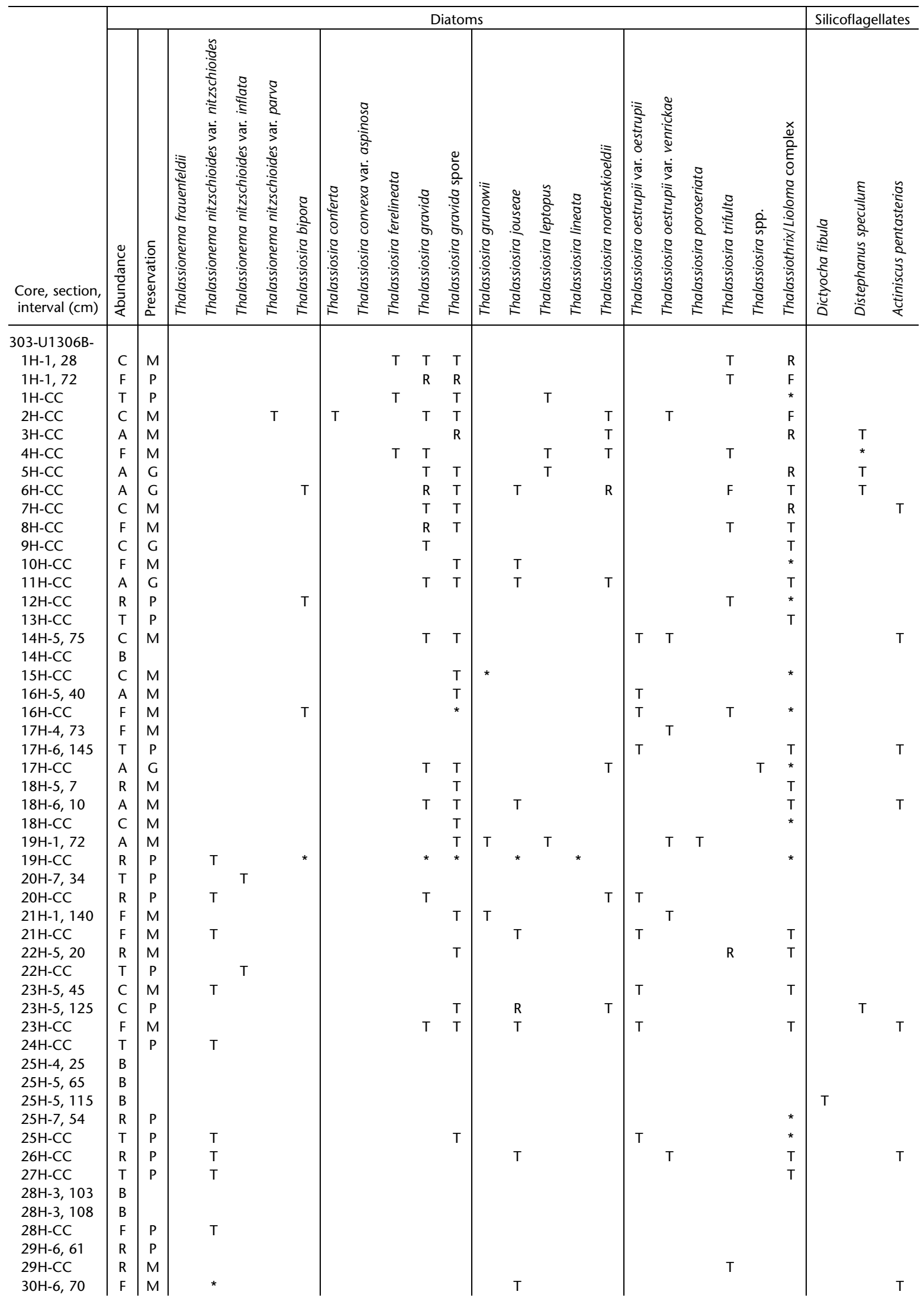


Table T12 (continued).

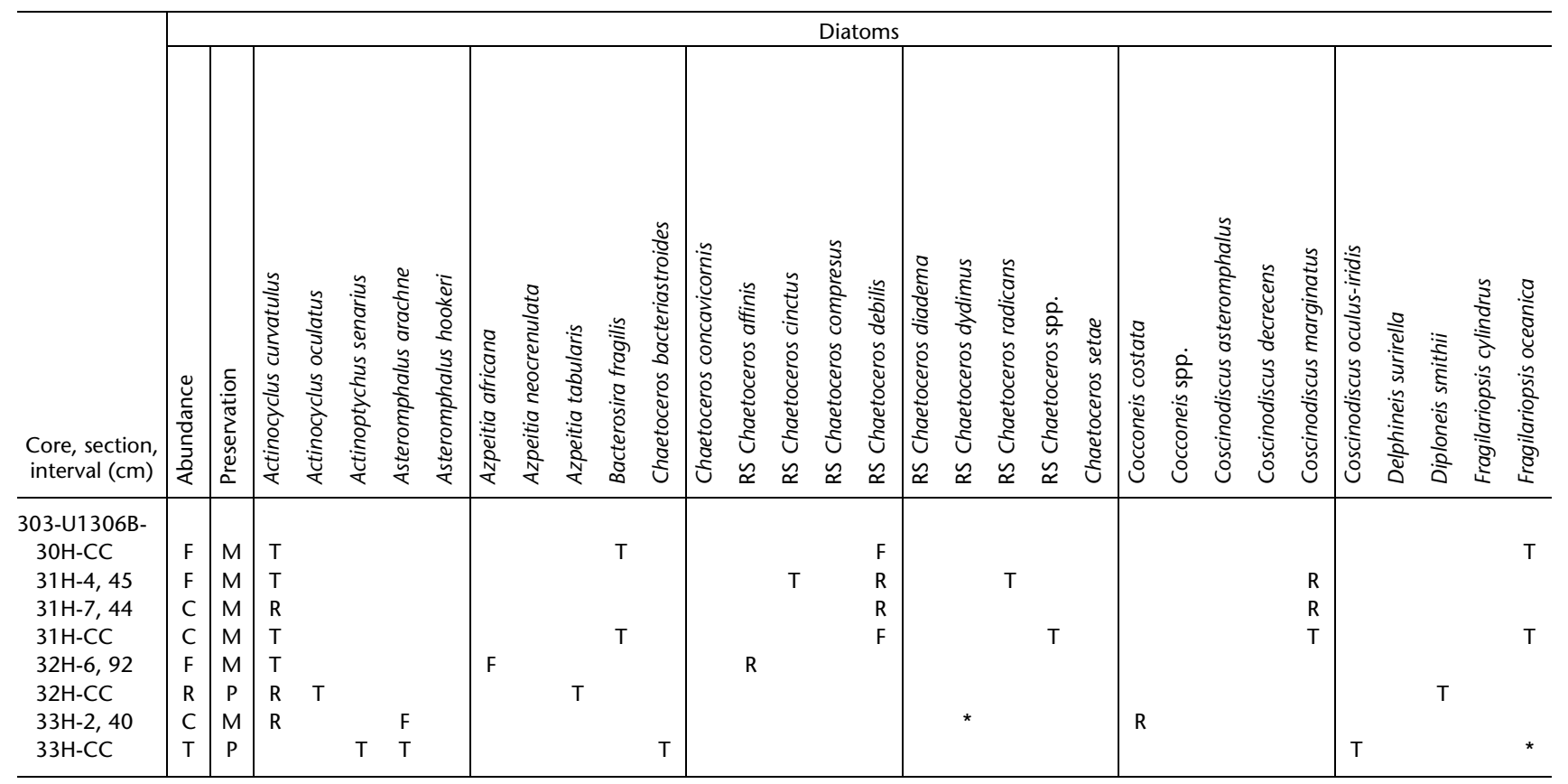

Notes: Abundance: $A=$ abundant, $C=$ common, $F=$ few, $R=$ rare, $T=$ trace, $B=$ barren. Preservation: $G=$ good, $M=$ moderate, $P=$ poor. $R S=$ resting spore. * $=$ fragment present.

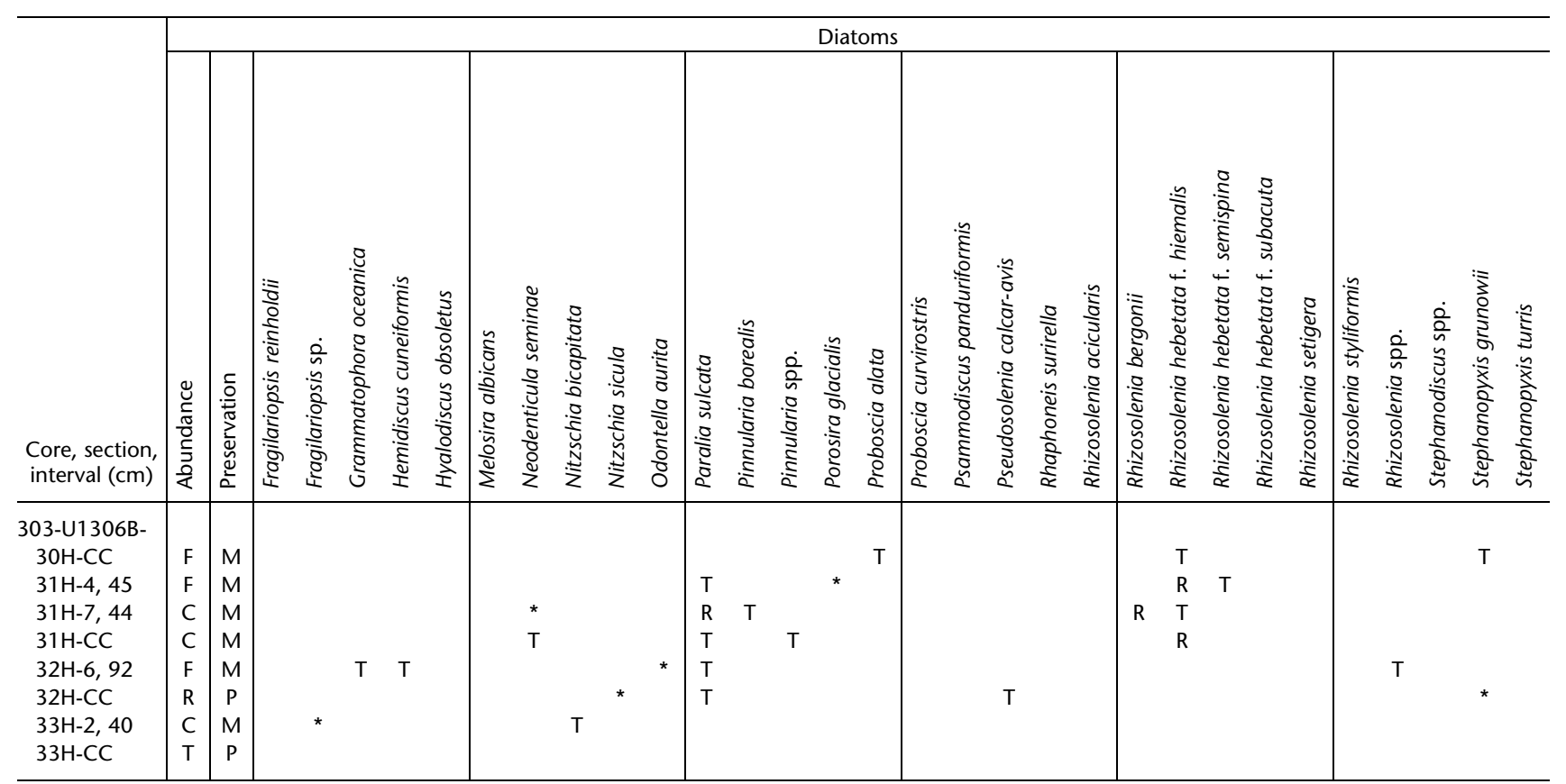


Table T12 (continued).

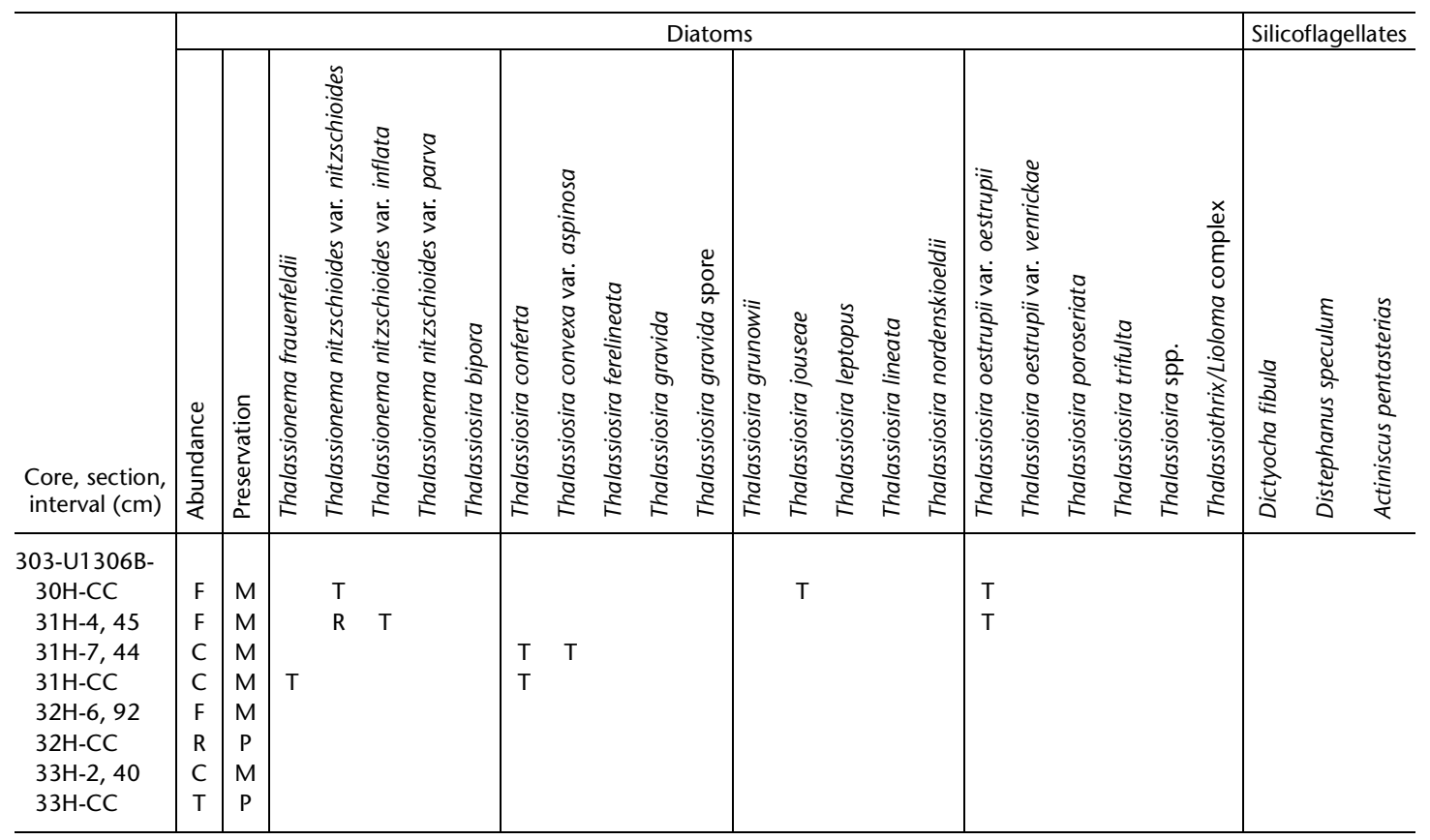


Table T13. Distribution of diatoms and silicoflagellates, Hole U1306C. (Continued on next page).

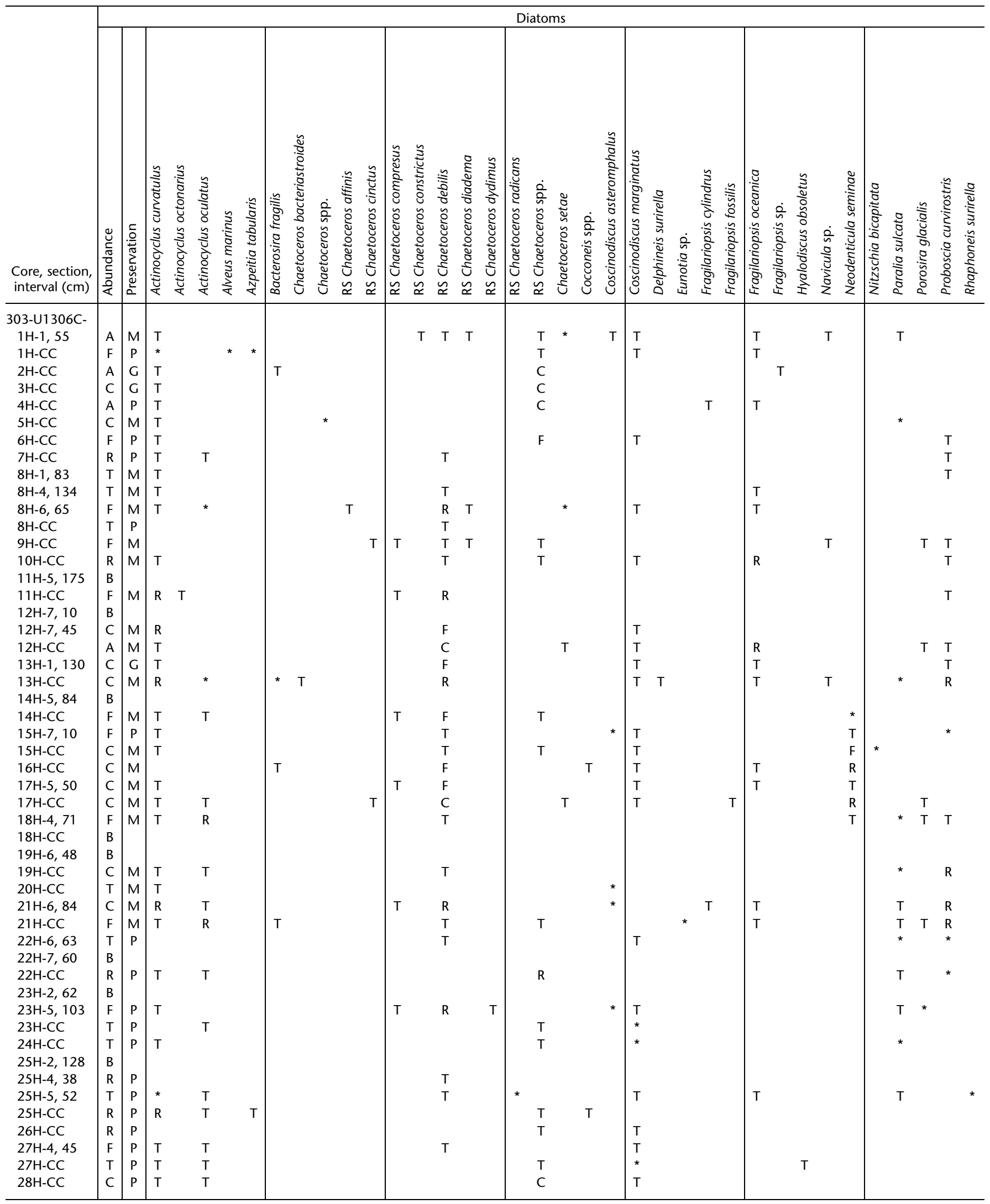

Notes: Abundance: $\mathrm{A}=$ abundant, $\mathrm{C}=$ common, $\mathrm{F}=$ few, $\mathrm{R}=$ rare, $\mathrm{T}=$ trace, $\mathrm{B}=$ barren. Preservation: $\mathrm{G}=\mathrm{good}, \mathrm{M}=\mathrm{moderate}, \mathrm{P}=$ poor. $\mathrm{RS}=$ resting spore. ${ }^{*}=$ fragment present. 
Table T13 (continued).

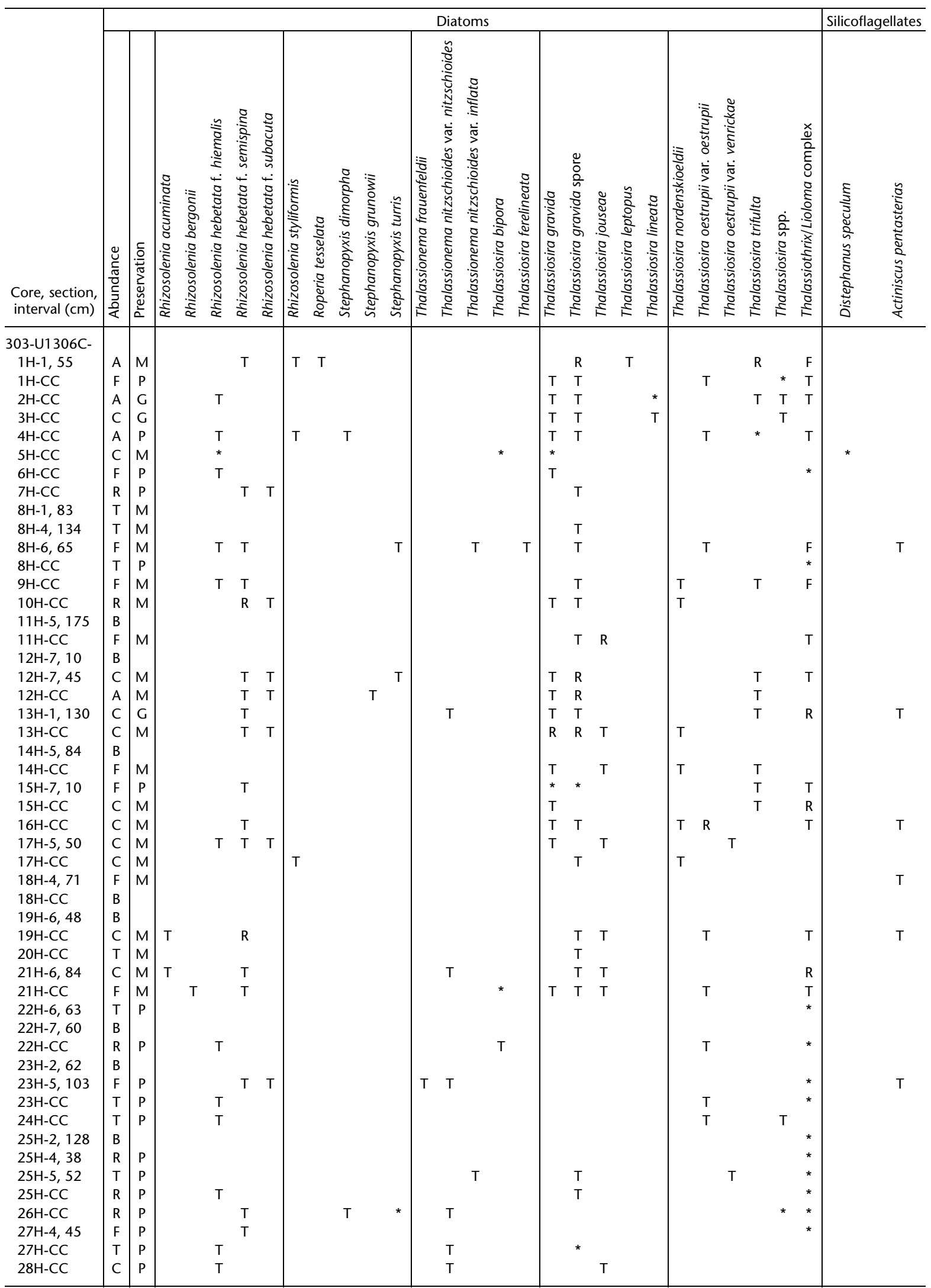


Table T14. Distribution of diatoms and silicoflagellates, Hole U1306D. (Continued on next page).

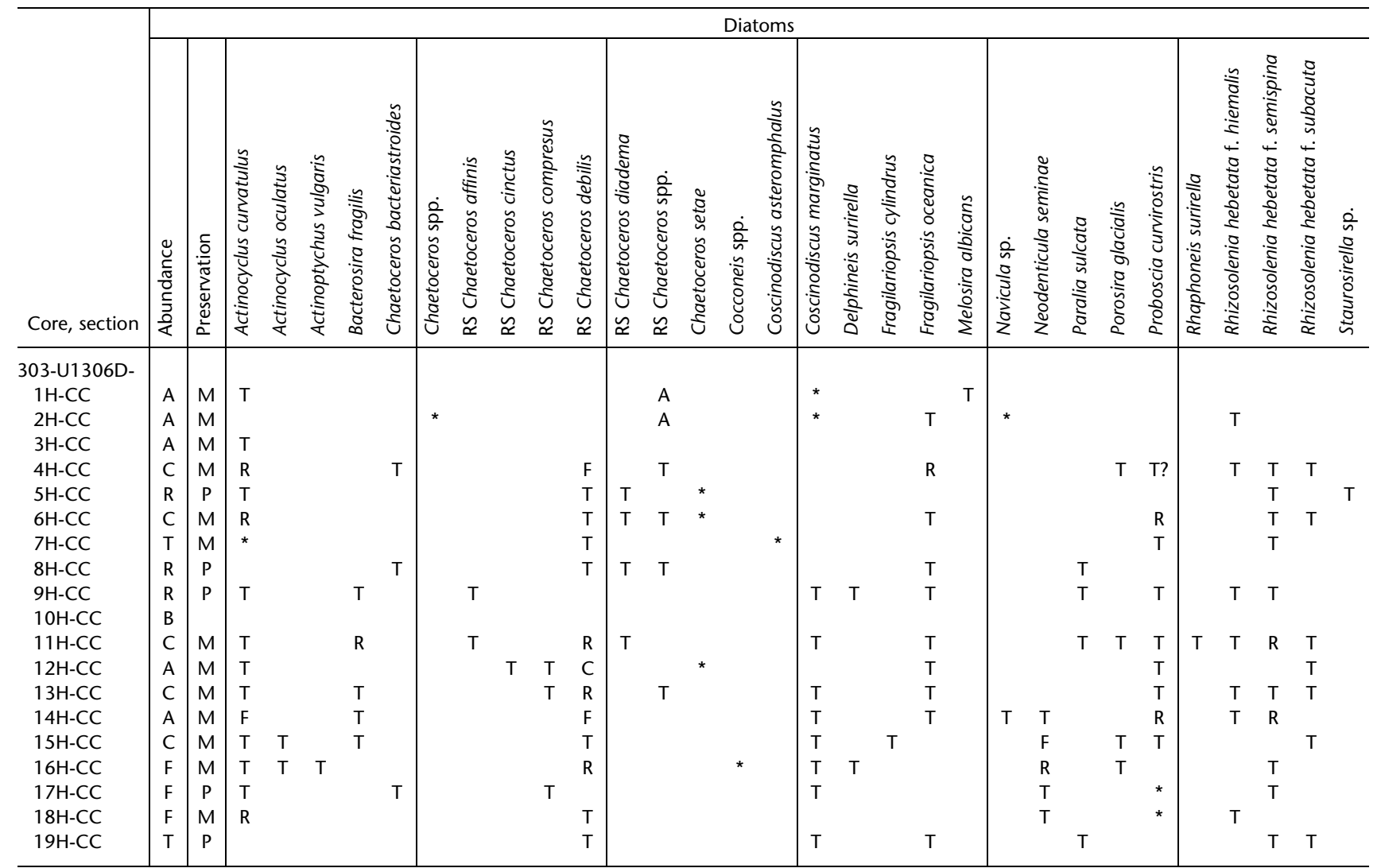

Notes: Abundance: $A=$ abundant, $C=$ common, $F=$ few, $R=$ rare, $T=$ trace, $B=$ barren. Preservation: $G=$ good, $M=$ moderate, $P=$ poor. $R S=$ resting spore. ${ }^{*}=$ fragment present. 
Table T14 (continued).

\begin{tabular}{|c|c|c|c|c|c|c|c|c|c|c|c|c|c|c|c|c|c|c|c|c|}
\hline \multirow[b]{2}{*}{$\begin{array}{l}\text { Core, section, } \\
\text { interval }(\mathrm{cm})\end{array}$} & \multicolumn{17}{|c|}{ Diatoms } & \multicolumn{3}{|c|}{ Silicoflagellates } \\
\hline & 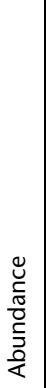 & 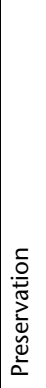 & 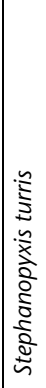 & 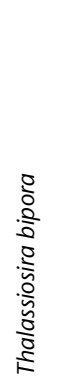 & 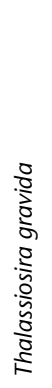 & 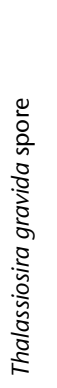 & 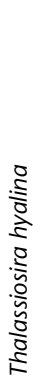 & 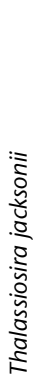 & 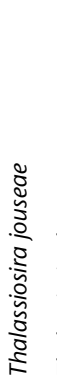 & 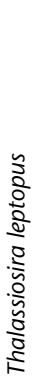 & 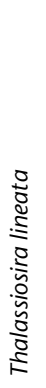 & 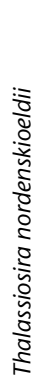 & 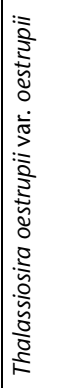 & 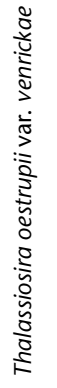 & 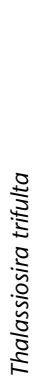 & 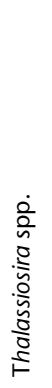 & 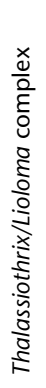 & 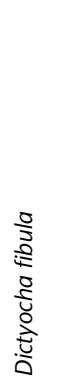 & 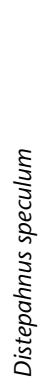 & 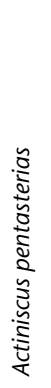 \\
\hline 303-U1306D- & & & & & & & & & & & & & & & & & & & & \\
\hline $1 \mathrm{H}-\mathrm{CC}$ & A & $M$ & & T & T & $\mathrm{T}$ & & & & & & & & & T & T & * & & & \\
\hline $2 \mathrm{H}-\mathrm{CC}$ & A & $M$ & & T & T & $\mathrm{T}$ & * & & & & $\mathrm{T}$ & * & & & & T & * & & & \\
\hline $3 \mathrm{H}-\mathrm{CC}$ & A & $M$ & & & T & $\mathrm{T}$ & & & & T & & & & & & T & T & * & & \\
\hline $4 \mathrm{H}-\mathrm{CC}$ & C & $M$ & & & T & $\mathrm{T}$ & & & & & & $\mathrm{T}$ & & & $\mathrm{T}$ & & $\mathrm{T}$ & & $\mathrm{T}$ & \\
\hline $5 \mathrm{H}-\mathrm{CC}$ & $\mathrm{R}$ & $P$ & & & $\mathrm{~T}$ & $\mathrm{~T}$ & & & & & & & & & & & & & & \\
\hline $6 \mathrm{H}-\mathrm{CC}$ & C & M & & & T & T & & & & & & & & & & & T & & & \\
\hline 7H-CC & T & $M$ & & & & & & & & & & & & & $\mathrm{~T}$ & & & & & \\
\hline $8 \mathrm{H}-\mathrm{CC}$ & $\mathrm{R}$ & $\mathrm{P}$ & & & & T & & & & & & & & & & & T & & & $\mathrm{T}$ \\
\hline $9 \mathrm{H}-\mathrm{CC}$ & $\mathrm{R}$ & $\mathrm{P}$ & & & & T & & & & & & T & T & & & & T & & & T \\
\hline $10 \mathrm{H}-\mathrm{CC}$ & B & & & & & & & & & & & & & & & & & & & \\
\hline $11 \mathrm{H}-\mathrm{CC}$ & C & M & & & $\mathrm{T}$ & T & & T & & & & & T & & $\mathrm{R}$ & & $\mathrm{R}$ & & & $\mathrm{T}$ \\
\hline $12 \mathrm{H}-\mathrm{CC}$ & A & $M$ & $\mathrm{~T}$ & & T & $\mathrm{R}$ & & & & & & $\mathrm{T}$ & & & & & T & & & \\
\hline $13 \mathrm{H}-\mathrm{CC}$ & C & $M$ & & & $\mathrm{~T}$ & $\mathrm{~T}$ & & & & & & $\mathrm{~T}$ & T & & & & & * & T & \\
\hline $14 \mathrm{H}-\mathrm{CC}$ & A & M & & & & $\mathrm{T}$ & & & $\mathrm{T}$ & & & & & & & & & & $\mathrm{T}$ & \\
\hline $15 \mathrm{H}-\mathrm{CC}$ & C & M & & & & T & & & T & & & & T & & & & T & & & \\
\hline $16 \mathrm{H}-\mathrm{CC}$ & $\mathrm{F}$ & $M$ & & & & $\mathrm{~T}$ & & & T & & & & & & & & T & & & \\
\hline $17 \mathrm{H}-\mathrm{CC}$ & $\mathrm{F}$ & $P$ & & & $\mathrm{~T}$ & $\mathrm{~T}$ & & & T & & & & T & $\mathrm{T}$ & & & T & & & \\
\hline $18 \mathrm{H}-\mathrm{CC}$ & $\mathrm{F}$ & M & & & & & & & & & & & & & & & & & & \\
\hline $19 \mathrm{H}-\mathrm{CC}$ & T & $P$ & & & $\mathrm{~T}$ & & & & & & & & & & & & T & & & T \\
\hline
\end{tabular}


Table T15. Distribution of radiolarians, Holes U1306A, U1306B, U1306C, and U1306D. (See table notes. Continued on next page).

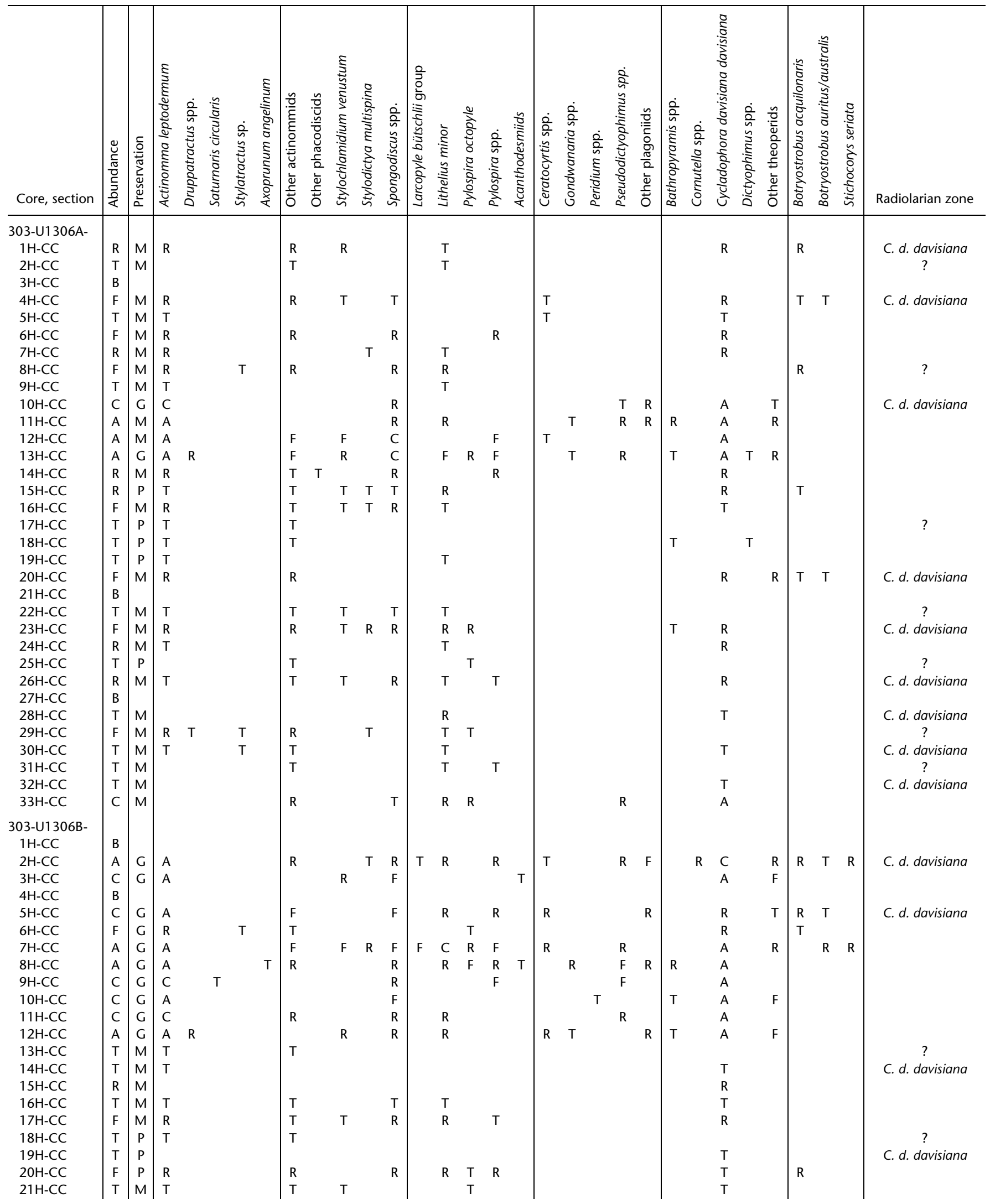


Table T15 (continued).

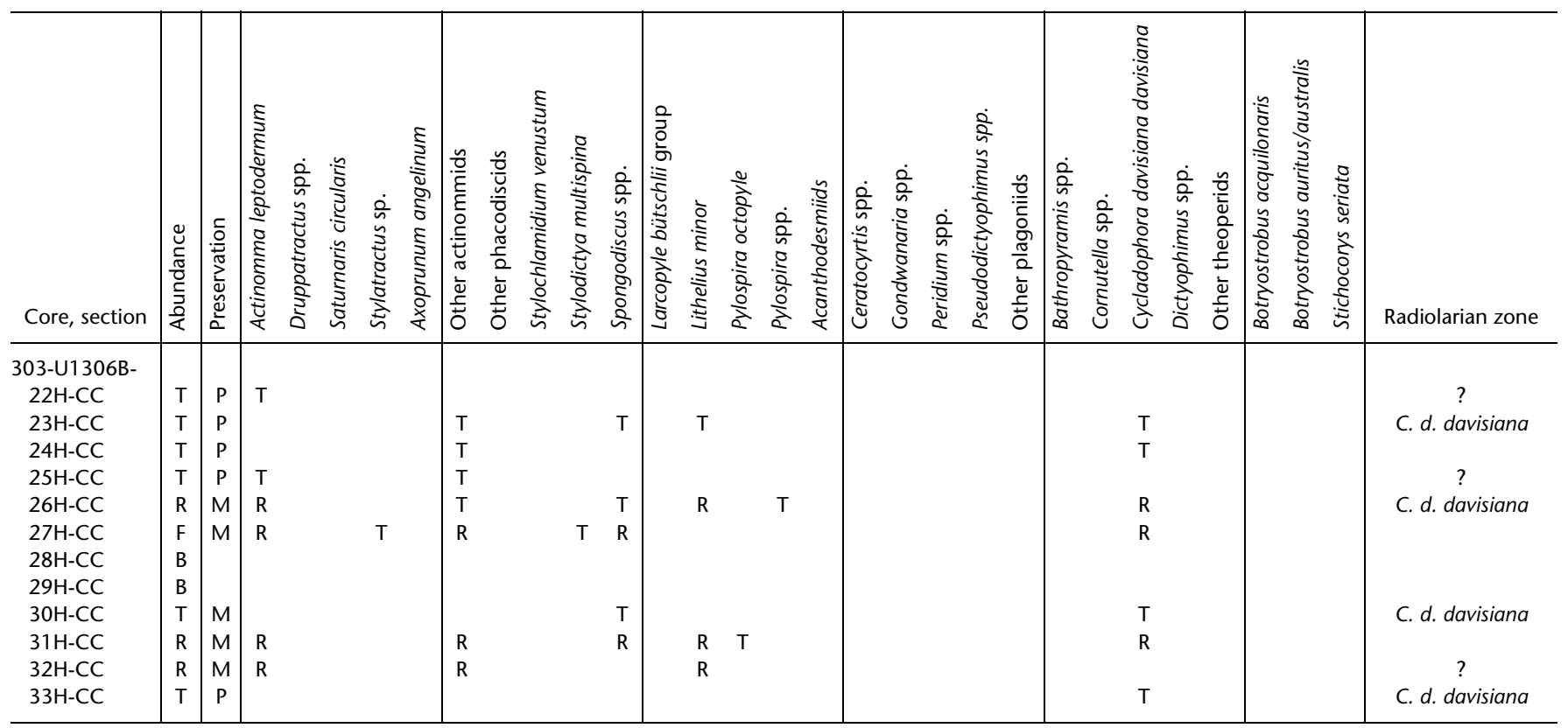

Notes: Abundance: $\mathrm{A}=$ abundant, $\mathrm{C}=$ common, $\mathrm{F}=$ few, $\mathrm{R}=$ rare, $\mathrm{T}=$ trace, $\mathrm{B}=$ barren (only in total abundance). Preservation: $\mathrm{G}=\mathrm{good}, \mathrm{M}=$ moderate, $\mathrm{P}=$ poor. $\mathrm{C}$. $d$. davisiana $=$ Cycladophora davisiana davisiana. 
Table T16. Distribution of palynomorphs, Hole U1306A.

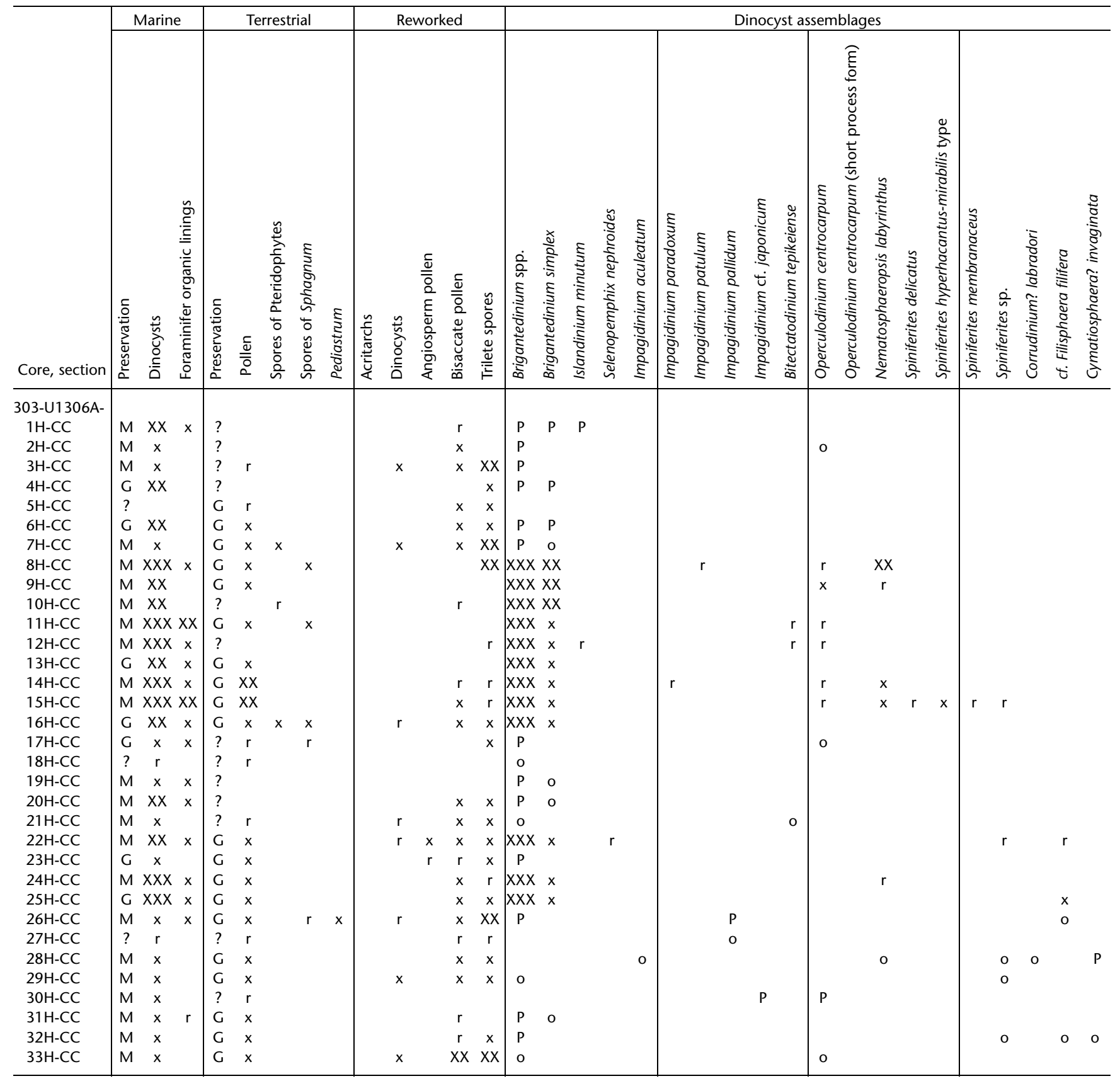

Notes: Absolute abundances: $X X X=$ abundant, $X X=$ common, $X=$ few, $r=$ rare. Relative abundance of dinocyst taxa: $X X X=$ dominant, $X X=$ common, $x=$ few, $r=$ rare, $P=$ presence, $o=$ single occurrence. Preservation: $G=$ good, $M=$ moderate. 
Table T17. Distribution of palynomorphs, Hole U1306D.

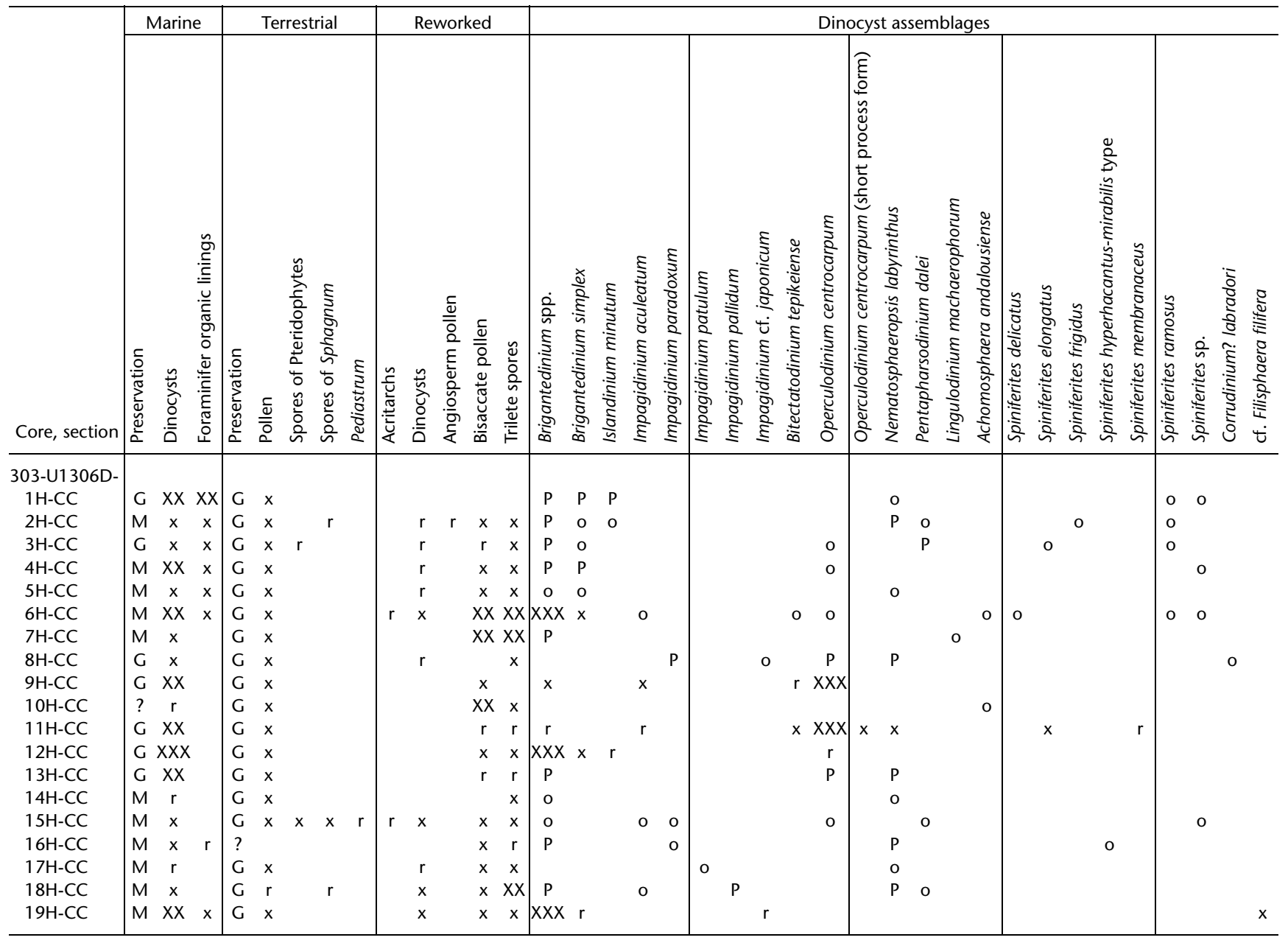

Notes: Absolute abundances: $X X X=$ abundant, $X X=$ common, $X=$ few,$r=$ rare. Relative abundance of dinocyst taxa: $X X X=d o m i n a n t, X X=$ common, $X=$ few, $r=$ rare, $P=$ presence, $O=$ single occurrence. Preservation: $G=$ good, $M=$ moderate. 
Table T18. Polarity zonation, Holes U1306A, U1306B, U1306C, and U1306D.

\begin{tabular}{|c|c|c|c|c|c|c|c|c|c|c|c|c|c|c|}
\hline \multirow[b]{2}{*}{ Polarity chron interpretation } & \multirow[b]{2}{*}{$\begin{array}{l}\text { Age } \\
(\mathrm{Ma})\end{array}$} & \multirow[b]{2}{*}{ Interval } & \multicolumn{3}{|c|}{ Hole U1306A } & \multicolumn{3}{|c|}{ Hole U1306B } & \multicolumn{3}{|c|}{ Hole U1306C } & \multicolumn{3}{|c|}{ Hole U1306D } \\
\hline & & & $\begin{array}{l}\text { Core, section, } \\
\text { interval }(\mathrm{cm})\end{array}$ & $\begin{array}{l}\text { Depth } \\
\text { (mbsf) }\end{array}$ & $\begin{array}{l}\text { Depth } \\
\text { (mcd) }\end{array}$ & $\begin{array}{l}\text { Core, section, } \\
\text { interval }(\mathrm{cm})\end{array}$ & $\begin{array}{l}\text { Depth } \\
\text { (mbsf) }\end{array}$ & $\begin{array}{l}\text { Depth } \\
\text { (mcd) }\end{array}$ & $\begin{array}{l}\text { Core, section, } \\
\text { interval }(\mathrm{cm})\end{array}$ & $\begin{array}{l}\text { Depth } \\
\text { (mbsf) }\end{array}$ & $\begin{array}{l}\text { Depth } \\
\text { (mcd) }\end{array}$ & $\begin{array}{l}\text { Core, section, } \\
\text { interval }(\mathrm{cm})\end{array}$ & $\begin{array}{l}\text { Depth } \\
\text { (mbsf) }\end{array}$ & $\begin{array}{l}\text { Depth } \\
\text { (mcd) }\end{array}$ \\
\hline C1n (b) Matuyama/Brunhes & 0.78 & $\begin{array}{l}\text { Upper } \\
\text { Lower }\end{array}$ & 303-U1306A- & & & $\begin{array}{c}303-U 1306 \mathrm{~B}- \\
13 \mathrm{H}-6,80 \\
14 \mathrm{H}-1,140\end{array}$ & $\begin{array}{l}114.12 \\
116.7\end{array}$ & $\begin{array}{l}122.65 \\
125.65\end{array}$ & $\begin{array}{c}303-U 1306 \mathrm{C}- \\
13 \mathrm{H}-3,70 \\
13 \mathrm{H}-4,120\end{array}$ & $\begin{array}{l}113.2 \\
115.2\end{array}$ & $\begin{array}{l}122.54 \\
124.54\end{array}$ & $\begin{array}{c}303-\mathrm{U} 1306 \mathrm{D}- \\
13 \mathrm{H}-2,135 \\
13 \mathrm{H}-3,45\end{array}$ & $\begin{array}{l}116.35 \\
116.95\end{array}$ & $\begin{array}{l}123.48 \\
124.08\end{array}$ \\
\hline C1r.1n (t) Jaramillo & 0.99 & $\begin{array}{l}\text { Upper } \\
\text { Lower }\end{array}$ & & & & $\begin{array}{l}16 \mathrm{H}-6,115 \\
17 \mathrm{H}-1,70\end{array}$ & $\begin{array}{l}142.96 \\
144.50\end{array}$ & $\begin{array}{l}153.25 \\
156.99\end{array}$ & $\begin{array}{l}16 \mathrm{H}-3,25 \\
16 \mathrm{H}-3,105\end{array}$ & $\begin{array}{l}141.25 \\
142.05\end{array}$ & $\begin{array}{l}153.64 \\
154.44\end{array}$ & & & \\
\hline C1r.1n (b) Jaramillo* & 1.07 & $\begin{array}{l}\text { Upper } \\
\text { Lower }\end{array}$ & $\begin{array}{l}17 \mathrm{H}-6,140 \\
18 \mathrm{H}-2,75\end{array}$ & $\begin{array}{l}151.70 \\
154.55\end{array}$ & $\begin{array}{l}164.23 \\
166.90\end{array}$ & $\begin{array}{l}17 \mathrm{H}-6,60 \\
18 \mathrm{H}-1,70\end{array}$ & $\begin{array}{l}151.91 \\
154.00\end{array}$ & $\begin{array}{l}164.60 \\
167.26\end{array}$ & $\begin{array}{l}17 \mathrm{H}-4,35 \\
17 \mathrm{H}-4,85\end{array}$ & $\begin{array}{l}152.35 \\
152.85\end{array}$ & $\begin{array}{l}165.28 \\
165.78\end{array}$ & $\begin{array}{l}17 \mathrm{H}-2,100 \\
17 \mathrm{H}-3,20\end{array}$ & $\begin{array}{l}153.59 \\
154.29\end{array}$ & $\begin{array}{l}165.28 \\
165.98\end{array}$ \\
\hline (t) Cobb Mountain & 1.19 & $\begin{array}{l}\text { Upper } \\
\text { Lower }\end{array}$ & $\begin{array}{l}19 \mathrm{H}-3,30 \\
19 \mathrm{H}-3,65\end{array}$ & $\begin{array}{l}165.07 \\
165.42\end{array}$ & $\begin{array}{l}178.62 \\
178.97\end{array}$ & & & & $\begin{array}{l}18 \mathrm{H}-5,35 \\
18 \mathrm{H}-6,35\end{array}$ & $\begin{array}{l}163.35 \\
164.85\end{array}$ & $\begin{array}{l}177.78 \\
179.28\end{array}$ & $\begin{array}{l}18 \mathrm{H}-3,100 \\
18 \mathrm{H}-4,20\end{array}$ & $\begin{array}{l}165.00 \\
179.08\end{array}$ & $\begin{array}{l}178.33 \\
179.03\end{array}$ \\
\hline (b) Cobb Mountain & 1.215 & $\begin{array}{l}\text { Upper } \\
\text { Lower }\end{array}$ & $\begin{array}{l}19 \mathrm{H}-6,5 \\
19 \mathrm{H}-6,75\end{array}$ & $\begin{array}{l}169.32 \\
170.02\end{array}$ & $\begin{array}{l}182.87 \\
183.57\end{array}$ & $\begin{array}{l}19 \mathrm{H}-1,130 \\
19 \mathrm{H}-2,120\end{array}$ & $\begin{array}{l}168.1 \\
169.5\end{array}$ & $\begin{array}{l}182.57 \\
183.97\end{array}$ & $\begin{array}{l}19 \mathrm{H}-1,110 \\
19 \mathrm{H}-2,55\end{array}$ & $\begin{array}{l}167.6 \\
168.55\end{array}$ & $\begin{array}{l}183.25 \\
184.20\end{array}$ & & & \\
\hline$C 2 n(t)$ Olduvai & 1.77 & $\begin{array}{l}\text { Upper } \\
\text { Lower }\end{array}$ & $\begin{array}{l}28 \mathrm{H}-8,45 \\
29 \mathrm{H}-1,70\end{array}$ & $\begin{array}{l}256.74 \\
257.50\end{array}$ & $\begin{array}{l}277.14 \\
278.87\end{array}$ & $\begin{array}{l}28 \mathrm{H}-3,105 \\
28 \mathrm{H}-4,100\end{array}$ & $\begin{array}{l}256.35 \\
257.8\end{array}$ & $\begin{array}{l}277.29 \\
278.74\end{array}$ & $\begin{array}{l}27 \mathrm{H}-2,25 \\
28 \mathrm{H}-1,85\end{array}$ & $\begin{array}{l}248.25 \\
256.85\end{array}$ & $\begin{array}{l}269.62 \\
278.54\end{array}$ & & & \\
\hline C2n (b) Olduvai & 1.95 & $\begin{array}{l}\text { Upper } \\
\text { Lower }\end{array}$ & $\begin{array}{l}32 \mathrm{H}-1,15 \\
32 \mathrm{H}-3,80\end{array}$ & $\begin{array}{l}286.45 \\
289.04\end{array}$ & $\begin{array}{l}310.4 \\
312.99\end{array}$ & $\begin{array}{l}31 \mathrm{H}-4,30 \\
31 \mathrm{H}-6,50\end{array}$ & $\begin{array}{l}285.10 \\
286.52\end{array}$ & $\begin{array}{l}309.76 \\
311.18\end{array}$ & & & & & & \\
\hline
\end{tabular}

Note: $(b)=$ bottom, $(\mathrm{t})=$ top. ${ }^{*}=$ coincides with prominent sand layer. 
Table T19. Age interpretation, Site U1306.

\begin{tabular}{llll}
\hline & \multirow{2}{*}{\begin{tabular}{c} 
Age \\
\cline { 3 - 4 } Polarity chron interpretation
\end{tabular}} & \multicolumn{2}{c}{ Depth } \\
\cline { 3 - 4 } & & (mcd) & $\pm(\mathrm{m})$ \\
\hline C1n (b) Matuyama/Brunhes & 0.78 & 123.5 & 1.5 \\
C1r.1n (t) Jaramillo & 0.99 & 154 & 1 \\
Cobb Mountain & 1.2 & 181 & 4 \\
C2n (t) Olduvai & 1.77 & 278.2 & 1 \\
C2n (b) Olduvai & 1.95 & 311.2 & 0.8 \\
\hline
\end{tabular}


Table T20. Shipboard composite and corrected composite depths, Holes U1306A, U1306B, U1306C, and U1306D.

\begin{tabular}{|c|c|c|c|c|}
\hline \multirow[b]{2}{*}{ Core } & \multirow{2}{*}{$\begin{array}{c}\text { Top depth } \\
\text { (mbsf) }\end{array}$} & \multirow{2}{*}{$\begin{array}{l}\text { Offset } \\
(\mathrm{m})\end{array}$} & \multicolumn{2}{|c|}{ Top depth } \\
\hline & & & (mcd) & (cmcd) \\
\hline \multicolumn{5}{|c|}{ 303-1306A- } \\
\hline $1 \mathrm{H}$ & 0.00 & 0.00 & 0.00 & 0.00 \\
\hline $2 \mathrm{H}$ & 8.30 & 0.72 & 9.02 & 8.35 \\
\hline $3 \mathrm{H}$ & 17.80 & 0.38 & 18.18 & 16.83 \\
\hline $4 \mathrm{H}$ & 27.30 & 2.09 & 29.39 & 27.21 \\
\hline $5 \mathrm{H}$ & 36.80 & 2.93 & 39.73 & 36.79 \\
\hline $6 \mathrm{H}$ & 46.30 & 4.09 & 50.39 & 46.66 \\
\hline $7 \mathrm{H}$ & 55.80 & 4.64 & 60.44 & 55.96 \\
\hline $8 \mathrm{H}$ & 65.30 & 5.10 & 70.40 & 65.19 \\
\hline $9 \mathrm{H}$ & 74.80 & 5.49 & 80.29 & 74.34 \\
\hline $10 \mathrm{H}$ & 84.30 & 6.54 & 90.84 & 84.11 \\
\hline $11 \mathrm{H}$ & 93.80 & 6.93 & 100.73 & 93.27 \\
\hline $12 \mathrm{H}$ & 103.30 & 7.04 & 110.34 & 102.17 \\
\hline $13 \mathrm{H}$ & 112.80 & 8.64 & 121.44 & 112.44 \\
\hline $14 \mathrm{H}$ & 122.30 & 9.29 & 131.59 & 121.84 \\
\hline $15 \mathrm{H}$ & 131.80 & 10.60 & 142.40 & 131.85 \\
\hline $16 \mathrm{H}$ & 141.30 & 10.47 & 151.77 & 140.53 \\
\hline $17 \mathrm{H}$ & 142.80 & 12.53 & 155.33 & 143.82 \\
\hline $18 \mathrm{H}$ & 152.30 & 12.35 & 164.65 & 152.45 \\
\hline $19 \mathrm{H}$ & 161.80 & 13.55 & 175.35 & 162.36 \\
\hline $20 \mathrm{H}$ & 171.30 & 13.25 & 184.55 & 170.88 \\
\hline $21 \mathrm{H}$ & 180.80 & 14.31 & 195.11 & 180.66 \\
\hline $22 \mathrm{H}$ & 190.30 & 15.09 & 205.39 & 190.18 \\
\hline $23 \mathrm{H}$ & 199.80 & 15.47 & 215.27 & 199.32 \\
\hline $24 \mathrm{H}$ & 209.30 & 15.54 & 224.84 & 208.19 \\
\hline $25 \mathrm{H}$ & 218.80 & 16.26 & 235.06 & 217.65 \\
\hline $26 \mathrm{H}$ & 228.30 & 18.01 & 246.31 & 228.06 \\
\hline $27 \mathrm{H}$ & 237.80 & 19.26 & 257.06 & 238.02 \\
\hline $28 \mathrm{H}$ & 247.30 & 20.40 & 267.70 & 247.87 \\
\hline $29 \mathrm{H}$ & 256.80 & 21.37 & 278.17 & 257.56 \\
\hline $30 \mathrm{H}$ & 266.30 & 22.05 & 288.35 & 266.99 \\
\hline $31 \mathrm{H}$ & 275.80 & 22.46 & 298.26 & 276.17 \\
\hline $32 \mathrm{H}$ & 285.30 & 23.95 & 309.25 & 286.34 \\
\hline $33 \mathrm{H}$ & 294.80 & 24.57 & 319.37 & 295.71 \\
\hline \multicolumn{5}{|c|}{ 303-U1306B- } \\
\hline $1 \mathrm{H}$ & 0.00 & 0.00 & 0.00 & 0.00 \\
\hline $2 \mathrm{H}$ & 1.30 & 0.87 & 2.17 & 2.01 \\
\hline $3 \mathrm{H}$ & 10.80 & 2.06 & 12.86 & 11.91 \\
\hline $4 \mathrm{H}$ & 20.30 & 2.74 & 23.04 & 21.33 \\
\hline $5 \mathrm{H}$ & 29.80 & 4.31 & 34.11 & 31.58 \\
\hline $6 \mathrm{H}$ & 39.30 & 5.74 & 45.04 & 41.70 \\
\hline $7 \mathrm{H}$ & 48.80 & 6.56 & 55.36 & 51.26 \\
\hline $8 \mathrm{H}$ & 58.30 & 7.31 & 65.61 & 60.75 \\
\hline $9 \mathrm{H}$ & 67.80 & 8.10 & 75.90 & 70.28 \\
\hline $10 \mathrm{H}$ & 77.30 & 8.25 & 85.55 & 79.21 \\
\hline $11 \mathrm{H}$ & 86.80 & 9.05 & 95.85 & 88.75 \\
\hline $12 \mathrm{H}$ & 96.30 & 8.79 & 105.09 & 97.31 \\
\hline $13 \mathrm{H}$ & 105.80 & 8.53 & 114.33 & 105.86 \\
\hline $14 \mathrm{H}$ & 115.30 & 8.95 & 124.25 & 115.05 \\
\hline $15 \mathrm{H}$ & 124.80 & 9.22 & 134.02 & 124.09 \\
\hline $16 \mathrm{H}$ & 134.30 & 10.29 & 144.59 & 133.88 \\
\hline $17 \mathrm{H}$ & 143.80 & 12.49 & 156.29 & 144.71 \\
\hline $18 \mathrm{H}$ & 153.30 & 13.26 & 166.56 & 154.22 \\
\hline $19 \mathrm{H}$ & 166.80 & 14.47 & 181.27 & 167.84 \\
\hline $20 \mathrm{H}$ & 176.30 & 15.39 & 191.69 & 177.49 \\
\hline $21 \mathrm{H}$ & 185.80 & 16.53 & 202.33 & 187.34 \\
\hline $22 \mathrm{H}$ & 195.30 & 17.16 & 212.46 & 196.72 \\
\hline $23 \mathrm{H}$ & 204.80 & 17.81 & 222.61 & 206.12 \\
\hline $24 \mathrm{H}$ & 214.30 & 18.23 & 232.53 & 215.31 \\
\hline
\end{tabular}

\begin{tabular}{lcccc}
\hline & \multirow{2}{*}{ Core } & $\begin{array}{c}\text { Top depth } \\
(\mathrm{mbsf})\end{array}$ & $\begin{array}{c}\text { Offset } \\
(\mathrm{m})\end{array}$ & \multicolumn{2}{c}{ Top depth } \\
\cline { 4 - 5 } & & & (mcd) & $(\mathrm{cmcd})$ \\
\hline $25 \mathrm{H}$ & 223.80 & 18.45 & 242.25 & 224.31 \\
$26 \mathrm{H}$ & 233.30 & 19.92 & 253.22 & 234.46 \\
$27 \mathrm{H}$ & 242.80 & 20.18 & 262.98 & 243.50 \\
$28 \mathrm{H}$ & 252.30 & 20.94 & 273.24 & 253.00 \\
$29 \mathrm{H}$ & 261.80 & 22.29 & 284.09 & 263.05 \\
$30 \mathrm{H}$ & 271.30 & 23.96 & 295.26 & 273.39 \\
$31 \mathrm{H}$ & 280.80 & 24.66 & 305.46 & 282.83 \\
$32 \mathrm{H}$ & 290.30 & 27.09 & 317.39 & 293.88 \\
$33 \mathrm{H}$ & 299.80 & 27.67 & 327.47 & 303.21
\end{tabular}

303-U1306C-

$\begin{array}{lrrrr}1 \mathrm{H} & 0.00 & 0.00 & 0.00 & 0.00 \\ 2 \mathrm{H} & 1.00 & 0.58 & 1.58 & 1.46 \\ 3 \mathrm{H} & 10.50 & 2.42 & 12.92 & 11.96 \\ 4 \mathrm{H} & 24.00 & 3.71 & 27.71 & 25.66 \\ 5 \mathrm{H} & 33.50 & 5.13 & 38.63 & 35.77 \\ 6 \mathrm{H} & 43.00 & 6.36 & 49.36 & 45.70 \\ 7 \mathrm{H} & 52.50 & 7.86 & 60.36 & 55.89 \\ 8 \mathrm{H} & 62.00 & 8.29 & 70.29 & 65.08 \\ 9 \mathrm{H} & 71.50 & 9.09 & 80.59 & 74.62 \\ 10 \mathrm{H} & 81.00 & 8.89 & 89.89 & 83.23 \\ 11 \mathrm{H} & 90.50 & 9.20 & 99.70 & 92.31 \\ 12 \mathrm{H} & 100.00 & 9.56 & 109.56 & 101.44 \\ 13 \mathrm{H} & 109.50 & 9.34 & 118.84 & 110.04 \\ 14 \mathrm{H} & 119.00 & 10.43 & 129.43 & 119.84 \\ 15 \mathrm{H} & 128.50 & 11.24 & 139.74 & 129.39 \\ 16 \mathrm{H} & 138.00 & 12.39 & 150.39 & 139.25 \\ 17 \mathrm{H} & 147.50 & 12.93 & 160.43 & 148.55 \\ 18 \mathrm{H} & 157.00 & 14.43 & 171.43 & 158.73 \\ 19 \mathrm{H} & 166.50 & 15.65 & 182.15 & 168.66 \\ 20 \mathrm{H} & 176.00 & 15.93 & 191.93 & 177.71 \\ 21 \mathrm{H} & 185.50 & 16.96 & 202.46 & 187.46 \\ 22 \mathrm{H} & 195.00 & 18.51 & 213.51 & 197.69 \\ 23 \mathrm{H} & 204.50 & 18.90 & 223.40 & 206.85 \\ 24 \mathrm{H} & 214.00 & 19.10 & 233.10 & 215.83 \\ 25 \mathrm{H} & 227.50 & 20.31 & 247.81 & 229.45 \\ 26 \mathrm{H} & 237.00 & 20.76 & 257.76 & 238.67 \\ 27 \mathrm{H} & 246.50 & 21.37 & 267.87 & 248.03 \\ 28 \mathrm{H} & 256.00 & 21.69 & 277.69 & 257.12\end{array}$

303-U1306D-

\begin{tabular}{lrrrr}
$1 \mathrm{H}$ & 0.00 & 0.05 & 0.05 & 0.05 \\
$2 \mathrm{H}$ & 7.00 & 1.12 & 8.12 & 7.52 \\
$3 \mathrm{H}$ & 16.50 & 2.11 & 18.61 & 17.23 \\
$4 \mathrm{H}$ & 26.00 & 2.91 & 28.91 & 26.77 \\
$5 \mathrm{H}$ & 35.50 & 3.44 & 38.94 & 36.06 \\
$6 \mathrm{H}$ & 45.00 & 4.86 & 49.86 & 46.17 \\
$7 \mathrm{H}$ & 54.50 & 5.88 & 60.38 & 55.91 \\
$8 \mathrm{H}$ & 64.00 & 6.78 & 70.78 & 65.54 \\
$9 \mathrm{H}$ & 73.50 & 6.19 & 79.69 & 73.79 \\
$10 \mathrm{H}$ & 85.00 & 7.10 & 92.10 & 85.28 \\
$11 \mathrm{H}$ & 94.50 & 6.76 & 101.26 & 93.76 \\
$12 \mathrm{H}$ & 104.00 & 6.93 & 110.93 & 102.71 \\
$13 \mathrm{H}$ & 113.50 & 7.13 & 120.63 & 111.69 \\
$14 \mathrm{H}$ & 123.00 & 8.58 & 131.58 & 121.83 \\
$15 \mathrm{H}$ & 132.50 & 8.81 & 141.31 & 130.84 \\
$16 \mathrm{H}$ & 142.00 & 10.38 & 152.38 & 141.09 \\
$17 \mathrm{H}$ & 151.50 & 13.33 & 164.83 & 152.62 \\
$18 \mathrm{H}$ & 161.00 & 11.69 & 172.69 & 159.90 \\
$19 \mathrm{H}$ & 170.50 & 14.65 & 185.15 & 171.44 \\
\hline
\end{tabular}


Table T21. Splice sections for Site U1306.

\begin{tabular}{|c|c|c|c|c|c|c|}
\hline \multirow{2}{*}{$\begin{array}{l}\text { Hole, core, section, } \\
\text { interval }(\mathrm{cm})\end{array}$} & \multicolumn{2}{|c|}{ Depth } & & \multirow{2}{*}{$\begin{array}{l}\text { Hole, core, section, } \\
\text { interval }(\mathrm{cm})\end{array}$} & \multicolumn{2}{|c|}{ Depth } \\
\hline & (mbsf) & $(\mathrm{mcd})$ & & & (mbsf) & (mcd) \\
\hline 1306B-1H-1, 78.0 & 0.78 & 0.78 & Tie to & 1306A-1H-1, 78.0 & 0.78 & 0.78 \\
\hline $1306 \mathrm{~A}-1 \mathrm{H}-4,137.5$ & 5.88 & 5.88 & Tie to & $1306 \mathrm{C}-2 \mathrm{H}-3,132.1$ & 5.30 & 5.88 \\
\hline $1306 \mathrm{C}-\mathrm{H} 2-6,28.3$ & 8.74 & 9.32 & Tie to & 1306D-2H-1, 120.0 & 8.20 & 9.32 \\
\hline 1306D-2H-6, 18.2 & 13.67 & 14.79 & Tie to & $1306 \mathrm{C}-3 \mathrm{H}-2,34.9$ & 12.37 & 14.79 \\
\hline $1306 \mathrm{C}-3 \mathrm{H}-6,11.4$ & 18.11 & 20.53 & Tie to & $1306 \mathrm{D}-3 \mathrm{H}-2,42.5$ & 18.42 & 20.53 \\
\hline 1306D-3H-5, 137.1 & 23.87 & 25.98 & Tie to & 1306B-4H-2, 144.1 & 23.24 & 25.98 \\
\hline 1306B-4H-5, 112.5 & 27.42 & 30.16 & Tie to & $1306 \mathrm{C}-4 \mathrm{H}-2,95.4$ & 26.45 & 30.16 \\
\hline 1306C-4H-7, 20.8 & 33.21 & 36.92 & Tie to & 1306B-5H-2, 131.2 & 32.61 & 36.92 \\
\hline 1306B-5H-5, 81.2 & 36.61 & 40.92 & Tie to & $1306 \mathrm{C}-5 \mathrm{H}-2,76.0$ & 35.79 & 40.92 \\
\hline $1306 \mathrm{C}-5 \mathrm{H}-6,111.2$ & 42.11 & 47.24 & Tie to & 1306B-6H-2, 71.9 & 41.50 & 47.24 \\
\hline 1306B-6H-6, 34.2 & 47.09 & 52.83 & Tie to & $1306 \mathrm{C}-6 \mathrm{H}-3,46.1$ & 46.47 & 52.83 \\
\hline $1306 \mathrm{C}-6 \mathrm{H}-6,58.7$ & 51.09 & 57.45 & Tie to & 1306B-7H-2, 58.2 & 50.89 & 57.45 \\
\hline 1306B-7H-6, 38.1 & 56.68 & 63.24 & Tie to & $1306 \mathrm{C}-7 \mathrm{H}-2,138.3$ & 55.38 & 63.24 \\
\hline $1306 \mathrm{C}-7 \mathrm{H}-6,117.4$ & 61.17 & 69.03 & Tie to & 1306B-8H-3, 42.3 & 61.72 & 69.03 \\
\hline 1306B-8H-6, 77.2 & 66.57 & 73.88 & Tie to & $1306 \mathrm{C}-8 \mathrm{H}-3,59.1$ & 65.59 & 73.88 \\
\hline $1306 \mathrm{C}-8 \mathrm{H}-6,33.1$ & 69.83 & 78.12 & Tie to & 1306B-9H-2, 72.1 & 70.02 & 78.12 \\
\hline 1306B-9H-5, 72.7 & 74.53 & 82.63 & Tie to & $1306 \mathrm{C}-9 \mathrm{H}-2,53.9$ & 73.54 & 82.63 \\
\hline $1306 \mathrm{C}-9 \mathrm{H}-6,58.9$ & 79.59 & 88.68 & Tie to & 1306B-10H-3, 12.7 & 80.43 & 88.68 \\
\hline 1306B-10H-6, 73.3 & 85.53 & 93.78 & Tie to & 1306A-10H-2, 141.9 & 87.24 & 93.78 \\
\hline $1306 \mathrm{~A}-10 \mathrm{H}-6,53.7$ & 92.38 & 98.92 & Tie to & 1306B-11H-3, 7.0 & 89.87 & 98.92 \\
\hline 1306B-11H-5, 97.4 & 93.77 & 102.82 & Tie to & $1306 \mathrm{D}-11 \mathrm{H}-2,6.0$ & 96.06 & 102.82 \\
\hline 1306D-11H-6, 62.3 & 102.66 & 109.42 & Tie to & 1306B-12H-3, 132.6 & 100.63 & 109.42 \\
\hline 1306B-12H-6, 80.3 & 104.60 & 113.39 & Tie to & $1306 \mathrm{~A}-12 \mathrm{H}-3,4.6$ & 106.35 & 113.39 \\
\hline $1306 \mathrm{~A}-12 \mathrm{H}-6,56.6$ & 111.37 & 118.41 & Tie to & 1306B-13H-3, 107.8 & 109.88 & 118.41 \\
\hline 1306B-13H-4, 125.7 & 111.56 & 120.09 & Tie to & $1306 \mathrm{C}-13 \mathrm{H}-1,124.5$ & 110.75 & 120.09 \\
\hline 1306C-13H-6, 23.9 & 117.24 & 126.58 & Tie to & 1306B-14H-2, 82.8 & 117.63 & 126.58 \\
\hline 1306B-14H-6, 38.9 & 123.19 & 132.14 & Tie to & $1306 \mathrm{C}-14 \mathrm{H}-2,118.7$ & 121.71 & 132.14 \\
\hline $1306 \mathrm{C} 14 \mathrm{H}-5,46.2$ & 125.46 & 135.89 & Tie to & 1306D-14H-3, 130.4 & 127.31 & 135.89 \\
\hline 1306D14H-6, 143.5 & 131.94 & 140.52 & Tie to & $1306 \mathrm{C}-15 \mathrm{H}-1,78.0$ & 129.28 & 140.52 \\
\hline $1306 \mathrm{C} 15 \mathrm{H}-6,133.8$ & 137.34 & 148.58 & Tie to & 1306B-16H-3, 95.7 & 138.29 & 148.58 \\
\hline 1306B16H-5, 129.0 & 141.60 & 151.89 & Tie to & $1306 \mathrm{C}-16 \mathrm{H}-1,149.6$ & 139.50 & 151.89 \\
\hline $1306 \mathrm{C}-16 \mathrm{H}-6,63.2$ & 146.13 & 158.52 & Tie to & 1306B-17H-2, 69.8 & 146.03 & 158.52 \\
\hline 1306B-17H-6, 54.1 & 151.85 & 164.34 & Tie to & $1306 \mathrm{C}-17 \mathrm{H}-3,90.6$ & 151.41 & 164.34 \\
\hline $1306 \mathrm{C}-17 \mathrm{H}-6,6.4$ & 155.06 & 167.99 & Tie to & 1306B-18H-1, 142.5 & 154.73 & 167.99 \\
\hline 1306B-18H-5, 124.1 & 160.51 & 173.77 & Tie to & $1306 \mathrm{C}-18 \mathrm{H}-2,80.4$ & 159.34 & 173.77 \\
\hline 1306C-18H-6, 138.9 & 165.89 & 180.32 & Tie to & $1306 \mathrm{~A}-19 \mathrm{H}-4,50.2$ & 166.77 & 180.32 \\
\hline 1306A-19H-5, 67.4 & 168.44 & 181.99 & Tie to & 1306B-19H-1, 72.0 & 167.52 & 181.99 \\
\hline 1306B-19H-6, 133.0 & 175.65 & 190.12 & Tie to & $1306 \mathrm{~A}-20 \mathrm{H}-4,107.6$ & 176.87 & 190.12 \\
\hline 1306A-20H-7, 29.5 & 180.60 & 193.85 & Tie to & 1306B-20H-2, 66.2 & 178.46 & 193.85 \\
\hline 1306B-20H-6, 3.9 & 183.85 & 199.24 & Tie to & 1306A-21H-3, 112.1 & 184.93 & 199.24 \\
\hline 1306A-21H-6, 92.0 & 189.22 & 203.53 & Tie to & 1306B-21H-1, 120.0 & 187.00 & 203.53 \\
\hline 1306B-21H-5, 144.8 & 193.26 & 209.79 & Tie to & 1306A-22H-3, 139.8 & 194.70 & 209.79 \\
\hline 1306A-22H-6, 145.2 & 199.25 & 214.34 & Tie to & 1306B-22H-2, 37.6 & 197.18 & 214.34 \\
\hline 1306B-22H-4, 3.6 & 199.84 & 217.00 & Tie to & $1306 \mathrm{~A}-23 \mathrm{H}-2,23.2$ & 201.53 & 217.00 \\
\hline 1306A-23H-6, 79.5 & 208.10 & 223.57 & Tie to & 1306B-23H-1, 96.0 & 205.76 & 223.57 \\
\hline 1306B-23H-4, 97.8 & 210.28 & 228.09 & Tie to & $1306 \mathrm{~A}-24 \mathrm{H}-3,22.7$ & 212.55 & 228.09 \\
\hline 1306A-24H-6, 111.8 & 217.92 & 233.46 & Tie to & 1306B-24H-1, 91.5 & 215.23 & 233.46 \\
\hline 1306B-24H-5, 84.2 & 221.14 & 239.37 & Tie to & 1306A-25H-3, 127.9 & 223.11 & 239.37 \\
\hline $1306 \mathrm{~A}-25 \mathrm{H}-6,24.0$ & 226.59 & 242.85 & Tie to & 1306B-25H-1, 60.0 & 224.40 & 242.85 \\
\hline 1306B-25H-6, 110.4 & 232.42 & 250.87 & Tie to & $1306 \mathrm{C}-25 \mathrm{H}-3,4.9$ & 230.56 & 250.87 \\
\hline $1306 \mathrm{C}-25 \mathrm{H}-6,8.8$ & 235.12 & 255.43 & Tie to & 1306B-26H-2, 69.2 & 235.51 & 255.43 \\
\hline 1306B-26H-6, 75.5 & 241.58 & 261.50 & Tie to & 1306A-27H-3, 141.1 & 242.24 & 261.50 \\
\hline 1306A-27H-6, 108.0 & 246.46 & 265.72 & Tie to & 1306B-27H-2, 122.8 & 245.54 & 265.72 \\
\hline 1306B-27H-6, 3.7 & 250.34 & 270.52 & Tie to & $1306 \mathrm{C}-27 \mathrm{H}-2,115.2$ & 249.15 & 270.52 \\
\hline $1306 \mathrm{C}-27 \mathrm{H}-6,92.0$ & 254.94 & 276.31 & Tie to & 1306B-28H-3, 1.4 & 255.37 & 276.31 \\
\hline 1306B-28H-5, 116.2 & 259.46 & 280.40 & Tie to & $1306 \mathrm{~A}-29 \mathrm{H}-2,72.9$ & 259.03 & 280.40 \\
\hline 1306A-29H-6, 144.7 & 265.80 & 287.17 & Tie to & 1306B-29H-3, 5.8 & 264.88 & 287.17 \\
\hline 1306B-29H-6, 7.1 & 269.37 & 291.66 & Tie to & $1306 \mathrm{~A}-30 \mathrm{H}-3,30.2$ & 269.61 & 291.66 \\
\hline 1306A-30H-6, 31.3 & 274.17 & 296.22 & Tie to & 1306B-30H-1, 96.0 & 272.26 & 296.22 \\
\hline $1306 \mathrm{~B}-30 \mathrm{H}-6,70.7$ & 279.51 & 303.47 & Tie to & $1306 \mathrm{~A}-31 \mathrm{H}-4,70.1$ & 281.01 & 303.47 \\
\hline 1306A-31H-6, 35.2 & 283.66 & 306.12 & Tie to & 1306B-31H-1, 63.0 & 281.46 & 306.12 \\
\hline 1306B-31H-7, 143.4 & 288.95 & 313.61 & Tie to & $1306 \mathrm{~A}-32 \mathrm{H}-3,141.3$ & 289.66 & 313.61 \\
\hline $1306 \mathrm{~A}-32 \mathrm{H}-6,146.0$ & 294.22 & 318.17 & Tie to & 1306B-32H-1, 78.0 & 291.08 & 318.17 \\
\hline 1306B-32H-3, 101.5 & 294.32 & 321.41 & Tie to & $1306 \mathrm{~A}-33 \mathrm{H}-2,54.0$ & 296.84 & 321.41 \\
\hline 1306A-33H-6, 131.5 & 303.62 & 328.19 & Tie to & $1306 \mathrm{~B}-33 \mathrm{H}-1,69.0$ & 300.52 & 328.19 \\
\hline 1306B-33H-7, 74.6 & 309.55 & 337.22 & & & & \\
\hline
\end{tabular}


Table T22. Sedimentation rates from paleomagnetic datums.

\begin{tabular}{cc}
\hline $\begin{array}{c}\text { Depth interval } \\
\text { (mcd) }\end{array}$ & $\begin{array}{c}\text { Sed. rate } \\
\text { (cm/k.y.) }\end{array}$ \\
\hline $0-123.5$ & 15.8 \\
$123.5-154.0$ & 14.5 \\
$154.0-181.0$ & 12.9 \\
$181.0-278.0$ & 17.0 \\
$278.0-311.0$ & 18.3 \\
\hline
\end{tabular}

Table T23. Headspace hydrocarbon gases, Hole U1306A.

\begin{tabular}{|c|c|c|c|c|c|}
\hline \multirow{2}{*}{$\begin{array}{l}\text { Core, section, } \\
\text { interval }(\mathrm{cm})\end{array}$} & \multicolumn{2}{|c|}{ Depth } & \multirow{2}{*}{$\begin{array}{c}\mathrm{C}_{1} / \mathrm{C}_{2} \\
\text { (ppmv) }\end{array}$} & \multirow{2}{*}{$\begin{array}{c}\mathrm{C}_{1} \\
\text { (ppmv) }\end{array}$} & \multirow{2}{*}{$\begin{array}{c}\mathrm{C}_{2} \\
(\mathrm{ppmv})\end{array}$} \\
\hline & (mbsf) & (mcd) & & & \\
\hline \multicolumn{6}{|l|}{ 303-U1306A- } \\
\hline $1 \mathrm{H}-2,0-5$ & 1.50 & 1.50 & & 0 & 0 \\
\hline $2 \mathrm{H}-2,0-5$ & 9.80 & 10.52 & & 16 & 0 \\
\hline $3 \mathrm{H}-2,0-5$ & 19.30 & 19.68 & & 14 & 0 \\
\hline $4 \mathrm{H}-2,0-5$ & 28.80 & 30.89 & & 92 & 0 \\
\hline $5 \mathrm{H}-2,0-5$ & 38.30 & 41.23 & & 113 & 0 \\
\hline $6 \mathrm{H}-2,0-5$ & 47.80 & 51.89 & & 157 & 0 \\
\hline $7 \mathrm{H}-2,0-5$ & 57.30 & 61.94 & & 281 & 0 \\
\hline $8 \mathrm{H}-2,0-5$ & 66.80 & 71.90 & & 259 & 0 \\
\hline $9 \mathrm{H}-2,0-5$ & 76.30 & 81.79 & & 505 & 0 \\
\hline $10 \mathrm{H}-2,0-5$ & 85.80 & 92.34 & & 1,034 & 0 \\
\hline $11 \mathrm{H}-2,0-5$ & 95.30 & 102.23 & & 2,992 & 0 \\
\hline $12 \mathrm{H}-2,0-5$ & 104.80 & 111.84 & & 4,129 & 0 \\
\hline $13 \mathrm{H}-2,0-5$ & 114.30 & 122.94 & & 5,954 & 0 \\
\hline $14 \mathrm{H}-2,0-5$ & 123.79 & 133.08 & 11,649 & 11,649 & 1.0 \\
\hline $15 \mathrm{H}-2,0-5$ & 133.29 & 143.89 & 11,381 & 13,657 & 1.2 \\
\hline $17 \mathrm{H}-2,0-5$ & 144.30 & 156.83 & 10,472 & 16,755 & 1.6 \\
\hline $18 \mathrm{H}-2,0-5$ & 153.80 & 166.15 & 9,286 & 19,501 & 2.1 \\
\hline $19 \mathrm{H}-2,0-5$ & 163.29 & 176.84 & 10,555 & 23,220 & 2.2 \\
\hline $20 \mathrm{H}-2,0-5$ & 172.79 & 186.04 & 9,919 & 26,781 & 2.7 \\
\hline $21 \mathrm{H}-2,0-5$ & 182.30 & 196.61 & 9,650 & 35,706 & 3.7 \\
\hline $22 \mathrm{H}-2,0-5$ & 191.80 & 206.89 & 9,806 & 17,651 & 1.8 \\
\hline $23 \mathrm{H}-2,0-5$ & 201.30 & 216.77 & 8,448 & 37,172 & 4.4 \\
\hline $24 \mathrm{H}-2,0-5$ & 210.80 & 226.34 & 8,720 & 38,367 & 4.4 \\
\hline $25 \mathrm{H}-2,0-5$ & 220.30 & 236.56 & 8,362 & 42,644 & 5.1 \\
\hline $26 \mathrm{H}-2,0-5$ & 229.80 & 247.81 & 7,864 & 36,959 & 4.7 \\
\hline $27 \mathrm{H}-2,0-5$ & 239.31 & 258.57 & 7,806 & 45,277 & 5.8 \\
\hline $28 \mathrm{H}-2,0-5$ & 248.80 & 269.20 & 6,883 & 37,169 & 5.4 \\
\hline $29 \mathrm{H}-2,0-5$ & 258.30 & 279.67 & 6,682 & 39,426 & 5.9 \\
\hline $30 \mathrm{H}-2,0-5$ & 267.80 & 289.85 & 6,387 & 45,345 & 7.1 \\
\hline $31 \mathrm{H}-2,0-5$ & 277.29 & 299.75 & 6,364 & 33,094 & 5.2 \\
\hline $32 \mathrm{H}-2,0-5$ & 286.80 & 310.75 & 6,279 & 37,044 & 5.9 \\
\hline $33 \mathrm{H}-2,0-5$ & 296.30 & 320.87 & 5,936 & 27,898 & 4.7 \\
\hline
\end{tabular}


Table T24. Bulk sedimentary carbon and nitrogen, Hole U1306A.

\begin{tabular}{|c|c|c|c|c|c|c|c|c|}
\hline \multirow{2}{*}{$\begin{array}{l}\text { Core, section, } \\
\text { interval }(\mathrm{cm})\end{array}$} & \multicolumn{2}{|c|}{ Depth } & \multicolumn{4}{|c|}{ Carbon (wt\%) } & \multirow{2}{*}{$\begin{array}{l}\text { Nitrogen } \\
\text { (wt\%) }\end{array}$} & \multirow{2}{*}{$\underset{\mathrm{C} / \mathrm{N}}{\text { Organic }}$} \\
\hline & (mbsf) & $(\mathrm{mcd})$ & Inorganic & $\mathrm{CaCO}_{3}$ & Total & Organic & & \\
\hline \multicolumn{9}{|l|}{ 303-U1306A- } \\
\hline $1 \mathrm{H}-1,133-134$ & 1.33 & 1.33 & 0.71 & 5.87 & 0.76 & 0.05 & 0.03 & 1.68 \\
\hline $1 \mathrm{H}-6,3-4$ & 7.53 & 7.53 & 0.33 & 2.75 & 0.52 & 0.19 & 0.04 & 5.45 \\
\hline $2 \mathrm{H}-1,133-133$ & 9.63 & 10.35 & 0.38 & 3.17 & 0.60 & 0.22 & 0.07 & 3.05 \\
\hline $2 \mathrm{H}-6,3-4$ & 15.83 & 16.55 & 0.39 & 3.25 & 0.50 & 0.11 & 0.05 & 2.01 \\
\hline $4 \mathrm{H}-1,138-139$ & 28.68 & 30.77 & 0.78 & 6.50 & 0.95 & 0.17 & 0.05 & 3.32 \\
\hline $4 \mathrm{H}-6,3-4$ & 34.83 & 36.92 & 0.36 & 3.00 & 0.54 & 0.18 & 0.05 & 3.49 \\
\hline $5 \mathrm{H}-1,138-139$ & 38.18 & 41.11 & 0.31 & 2.58 & 0.39 & 0.08 & 0.05 & 1.69 \\
\hline $5 \mathrm{H}-6,3-4$ & 43.50 & 46.43 & 0.54 & 4.50 & 0.61 & 0.07 & 0.04 & 1.65 \\
\hline $6 \mathrm{H}-1,138-139$ & 47.68 & 51.77 & 0.69 & 5.75 & 0.59 & 0.00 & 0.03 & 0.00 \\
\hline $6 \mathrm{H}-6,3-4$ & 53.83 & 57.92 & 0.23 & 1.92 & 0.45 & 0.22 & 0.04 & 5.22 \\
\hline 7H-1, 138-139 & 57.18 & 61.82 & 0.87 & 7.21 & 0.93 & 0.06 & 0.04 & 1.48 \\
\hline $7 \mathrm{H}-6,3-4$ & 63.33 & 67.97 & 0.48 & 4.00 & 1.00 & 0.52 & 0.08 & 6.76 \\
\hline $8 \mathrm{H}-1,149-150$ & 66.79 & 71.89 & 0.23 & 1.92 & 0.49 & 0.26 & 0.06 & 4.53 \\
\hline $8 \mathrm{H}-6,0-1$ & 72.80 & 77.90 & 1.50 & 12.5 & 1.69 & 0.19 & 0.04 & 5.10 \\
\hline $9 \mathrm{H}-1,148-149$ & 76.28 & 81.77 & 0.84 & 7.00 & 0.95 & 0.11 & 0.06 & 1.86 \\
\hline $9 \mathrm{H}-6,0-1$ & 82.30 & 87.79 & 0.43 & 3.58 & 0.44 & 0.01 & 0.04 & 0.35 \\
\hline $10 \mathrm{H}-1,142-143$ & 85.72 & 92.26 & 0.93 & 7.75 & 1.13 & 0.20 & 0.04 & 5.06 \\
\hline $10 \mathrm{H}-6,0-1$ & 91.84 & 98.38 & 0.15 & 1.25 & 0.50 & 0.35 & 0.09 & 4.00 \\
\hline $11 \mathrm{H}-1,149-150$ & 95.29 & 102.22 & 0.29 & 2.42 & 0.75 & 0.46 & 0.08 & 5.65 \\
\hline $11 \mathrm{H}-6,1-2$ & 101.31 & 108.24 & 0.10 & 0.83 & 0.50 & 0.40 & 0.07 & 5.40 \\
\hline $12 \mathrm{H}-1,149-150$ & 104.79 & 111.83 & 1.32 & 11.0 & 1.41 & 0.09 & 0.04 & 2.21 \\
\hline $12 \mathrm{H}-6,0-1$ & 110.80 & 117.84 & 0.12 & 1.00 & 0.34 & 0.22 & 0.04 & 5.47 \\
\hline $14 \mathrm{H}-1,148-149$ & 123.78 & 133.07 & 0.18 & 1.50 & 0.48 & 0.30 & 0.08 & 3.84 \\
\hline $14 \mathrm{H}-6,3-4$ & 129.79 & 139.08 & 0.48 & 4.00 & 0.92 & 0.44 & 0.10 & 4.68 \\
\hline $15 \mathrm{H}-1,148-149$ & 133.28 & 143.88 & 0.64 & 5.33 & 0.85 & 0.21 & 0.04 & 5.56 \\
\hline $15 \mathrm{H}-6,3-4$ & 139.26 & 149.86 & 0.27 & 2.25 & 0.57 & 0.30 & 0.04 & 7.17 \\
\hline $17 \mathrm{H}-1,143-144$ & 144.23 & 156.76 & 0.05 & 0.42 & 0.41 & 0.36 & 0.08 & 4.35 \\
\hline $17 \mathrm{H}-6,3-4$ & 150.33 & 162.86 & 0.34 & 2.83 & 0.56 & 0.22 & 0.05 & 4.82 \\
\hline $18 \mathrm{H}-1,143-144$ & 153.73 & 166.08 & 0.23 & 1.92 & 0.51 & 0.28 & 0.07 & 4.12 \\
\hline $18 \mathrm{H}-6,3-4$ & 159.83 & 172.18 & 0.04 & 0.33 & 0.17 & 0.13 & 0.04 & 3.60 \\
\hline $19 \mathrm{H}-1,143-144$ & 163.23 & 176.78 & 0.03 & 0.25 & 0.34 & 0.31 & 0.06 & 5.07 \\
\hline $20 \mathrm{H}-1,143-144$ & 172.73 & 185.98 & 0.06 & 0.50 & 0.22 & 0.16 & 0.04 & 3.76 \\
\hline $20 \mathrm{H}-6,3-4$ & 178.83 & 192.08 & 0.07 & 0.58 & 0.38 & 0.31 & 0.08 & 3.82 \\
\hline $21 \mathrm{H}-1,143-144$ & 182.23 & 196.54 & 0.04 & 0.33 & 0.30 & 0.26 & 0.07 & 3.86 \\
\hline $21 \mathrm{H}-6,3-4$ & 188.33 & 202.64 & 0.08 & 0.67 & 0.71 & 0.63 & 0.07 & 9.23 \\
\hline $22 \mathrm{H}-1,143-144$ & 191.73 & 206.82 & 0.94 & 7.83 & 1.15 & 0.21 & 0.04 & 5.62 \\
\hline $22 \mathrm{H}-6,3-4$ & 197.83 & 212.92 & 0.04 & 0.33 & 0.39 & 0.35 & 0.06 & 6.17 \\
\hline $23 \mathrm{H}-1,143-144$ & 201.23 & 216.70 & 0.34 & 2.83 & 1.43 & 1.09 & 0.09 & 12.7 \\
\hline $23 \mathrm{H}-6,0-1$ & 207.30 & 222.77 & 0.05 & 0.42 & 0.41 & 0.36 & 0.06 & 6.27 \\
\hline $24 \mathrm{H}-1,149-150$ & 210.79 & 226.33 & 0.03 & 0.25 & 0.22 & 0.19 & 0.04 & 5.29 \\
\hline $24 \mathrm{H}-6,1-2$ & 216.81 & 232.35 & 0.13 & 1.08 & 0.62 & 0.49 & 0.06 & 8.13 \\
\hline $25 \mathrm{H}-1,149-150$ & 220.29 & 236.55 & 0.04 & 0.33 & 0.34 & 0.30 & 0.05 & 5.93 \\
\hline $25 \mathrm{H}-6,0-1$ & 226.35 & 242.61 & 0.21 & 1.75 & 0.63 & 0.42 & 0.06 & 7.12 \\
\hline $26 \mathrm{H}-1,144-145$ & 229.74 & 247.75 & 0.04 & 0.33 & 0.43 & 0.39 & 0.06 & 6.17 \\
\hline $26 \mathrm{H}-6,1-2$ & 235.86 & 253.87 & 0.95 & 7.91 & 1.26 & 0.31 & 0.04 & 8.02 \\
\hline $27 \mathrm{H}-1,149-150$ & 239.29 & 258.55 & 0.09 & 0.75 & 0.45 & 0.36 & 0.06 & 6.04 \\
\hline $27 \mathrm{H}-6,1-2$ & 245.39 & 264.65 & 0.30 & 2.50 & 0.50 & 0.20 & 0.04 & 4.97 \\
\hline $28 \mathrm{H}-1,143-144$ & 248.73 & 269.13 & 0.09 & 0.75 & 0.49 & 0.40 & 0.06 & 6.57 \\
\hline $29 \mathrm{H}-2,3-4$ & 258.33 & 279.70 & 0.09 & 0.75 & 0.52 & 0.43 & 0.07 & 6.20 \\
\hline $29 \mathrm{H}-6,3-4$ & 264.38 & 285.75 & 0.56 & 4.66 & 0.99 & 0.43 & 0.07 & 6.12 \\
\hline $30 \mathrm{H}-1,143-144$ & 267.73 & 289.78 & 0.04 & 0.33 & 0.43 & 0.39 & 0.06 & 6.15 \\
\hline $30 \mathrm{H}-6,3-4$ & 273.89 & 295.94 & 0.65 & 5.41 & 0.98 & 0.33 & 0.06 & 5.93 \\
\hline $31 \mathrm{H}-1,143-144$ & 277.23 & 299.69 & 0.78 & 6.50 & 1.11 & 0.33 & 0.05 & 6.34 \\
\hline $31 \mathrm{H}-6,3-4$ & 283.34 & 305.80 & 0.85 & 7.08 & 1.07 & 0.22 & 0.04 & 4.95 \\
\hline $32 \mathrm{H}-1,3-4$ & 285.33 & 309.28 & 0.33 & 2.75 & 0.61 & 0.28 & 0.06 & 4.94 \\
\hline
\end{tabular}


Table T25. Interstitial water geochemistry, Hole U1306A.

\begin{tabular}{|c|c|c|c|c|c|c|c|c|c|c|c|c|c|c|c|c|c|c|c|c|}
\hline \multirow{2}{*}{$\begin{array}{l}\text { Core, section, } \\
\text { interval }(\mathrm{cm})\end{array}$} & \multicolumn{2}{|c|}{ Depth } & \multicolumn{2}{|c|}{ Anions (mM) } & \multirow[b]{2}{*}{$\mathrm{pH}$} & \multirow{2}{*}{$\begin{array}{l}\text { Alkalinity } \\
(\mathrm{mM})\end{array}$} & \multirow{2}{*}{$\begin{array}{l}\text { Salinity } \\
(\mathrm{g} / \mathrm{kg})\end{array}$} & \multicolumn{4}{|c|}{ Major cations (mM) } & \multicolumn{8}{|c|}{ Minor and trace constituents $(\mu \mathrm{M})$} & \multirow{2}{*}{$\begin{array}{c}\mathrm{Sr} / \mathrm{Ca} \\
(\mu \mathrm{M} / \mathrm{mM})\end{array}$} \\
\hline & (mbsf) & (mcd) & $\mathrm{SO}_{4}{ }^{2-}$ & $\mathrm{Cl}^{-}$ & & & & $\mathrm{Na}^{+}$ & $\mathrm{K}^{+}$ & $\mathrm{Mg}^{2+}$ & $\mathrm{Ca}^{2+}$ & $\mathrm{NH}_{4}^{+}$ & B & $\mathrm{Ba}^{2+}$ & $\mathrm{Fe}^{2+}$ & $\mathrm{Li}^{+}$ & $\mathrm{Mn}^{2+}$ & $\mathrm{H}_{4} \mathrm{SiO}_{4}$ & $\mathrm{Sr}^{2+}$ & \\
\hline \multicolumn{21}{|l|}{ 303-U1306A- } \\
\hline $1 \mathrm{H}-1,145-150$ & 1.45 & 1.45 & 27.90 & 560 & 7.02 & 3.94 & 36 & 486 & 12.0 & 50.9 & 10.2 & 55 & 462 & 0.3 & 0.1 & 20.3 & 27.3 & 487 & 81.6 & 8.0 \\
\hline $2 \mathrm{H}-1,145-150$ & 9.75 & 10.47 & 21.60 & 562 & 7.30 & 9.38 & 36 & 487 & 11.6 & 49.8 & 8.6 & 489 & 537 & 0.5 & 10.9 & 16.6 & 33.3 & 682 & 78.0 & 9.1 \\
\hline $3 \mathrm{H}-1,145-150$ & 19.25 & 19.63 & 17.40 & 568 & 7.28 & 11.20 & 36 & 490 & 11.7 & 48.8 & 7.3 & 614 & 534 & 0.3 & 24.4 & 15.4 & 25.2 & 643 & 73.7 & 10.1 \\
\hline $4 \mathrm{H}-1,145-150$ & 28.75 & 30.84 & 11.70 & 568 & 7.36 & 13.10 & 35 & 485 & 11.3 & 47.5 & 6.8 & 685 & 526 & 0.1 & 15.8 & 14.1 & 36.0 & 665 & 70.3 & 10.4 \\
\hline $5 \mathrm{H}-1,145-150$ & 38.25 & 41.18 & 11.00 & 570 & 7.35 & 14.10 & 35 & 490 & 10.8 & 46.1 & 6.0 & 746 & 559 & 0.4 & 12.8 & 14.5 & 31.5 & 765 & 68.7 & 11.5 \\
\hline $6 \mathrm{H}-1,145-150$ & 47.75 & 51.84 & 8.48 & 571 & 7.42 & 14.90 & 35 & 491 & 10.7 & 45.5 & 5.1 & 832 & 515 & 0.3 & 18.2 & 15.0 & 15.6 & 719 & 66.5 & 13.2 \\
\hline 7H-1, 145-150 & 57.25 & 61.89 & 4.58 & 570 & 7.46 & 15.50 & 35 & 488 & 10.3 & 44.5 & 4.0 & 879 & 504 & 0.4 & 17.9 & 15.8 & 12.0 & 682 & 66.6 & 16.7 \\
\hline $10 \mathrm{H}-1,145-150$ & 85.75 & 92.29 & 0.66 & 570 & 7.48 & 18.70 & 34 & 489 & 9.5 & 42.2 & 3.7 & 1123 & 519 & 9.9 & 12.0 & 14.6 & 7.9 & 677 & 74.7 & 20.1 \\
\hline $13 \mathrm{H}-1,145-150$ & 114.25 & 122.89 & 0.43 & 571 & 7.40 & 18.40 & 34 & 491 & 9.1 & 40.6 & 4.6 & 1289 & 519 & 10.3 & 23.5 & 14.8 & 10.9 & 824 & 76.4 & 16.6 \\
\hline $17 \mathrm{H}-1,145-150$ & 144.25 & 156.78 & 0.50 & 575 & 7.69 & 18.70 & 33 & 495 & 9.2 & 39.7 & 5.3 & 1386 & 447 & 7.4 & 8.3 & 17.1 & 7.5 & 751 & 79.3 & 14.9 \\
\hline $20 \mathrm{H}-1,144-149$ & 172.74 & 185.99 & 1.14 & 572 & 7.44 & 18.00 & 35 & 494 & 8.8 & 38.8 & 5.9 & 1548 & 519 & 8.0 & 22.1 & 19.6 & 14.4 & 893 & 83.8 & 14.2 \\
\hline $23 \mathrm{H}-1,145-150$ & 201.25 & 216.72 & 1.31 & 573 & 7.27 & 16.50 & 34 & 495 & 8.2 & 38.3 & 6.3 & 1782 & 523 & 8.4 & 41.9 & 24.0 & 10.8 & 945 & 83.8 & 13.3 \\
\hline $26 \mathrm{H}-1,145-150$ & 229.75 & 247.76 & 1.08 & 577 & 7.37 & 15.80 & 35 & 497 & 7.9 & 38.1 & 7.2 & 1719 & 471 & 9.0 & 25.3 & 27.6 & 10.8 & 928 & 87.5 & 12.3 \\
\hline $29 \mathrm{H}-1,145-150$ & 258.25 & 279.62 & 0.63 & 577 & 7.52 & 14.50 & 34 & 495 & 7.7 & 37.1 & 7.8 & 1802 & 411 & 11.5 & 15.8 & 31.9 & 14.6 & 882 & 93.0 & 12.0 \\
\hline $32 \mathrm{H}-1,145-150$ & 286.75 & 310.70 & 0.04 & 581 & 7.34 & 11.10 & 34 & 496 & 7.4 & 36.3 & 7.8 & 1951 & 432 & 11.8 & 33.5 & 38.3 & 6.3 & 918 & 95.2 & 12.2 \\
\hline
\end{tabular}

